\title{
Çetin Baraj Gövdesi ve Dolayının Jeolojisi ve Heyelan Araştırması
}

\author{
Geology and Landslide Investigations in and Around the Çetin Dam Site
}

\author{
Doğan PERÍNÇEK \\ Emekli, Çanakkale Onsekiz Mart Üniversitesi, Mühendislik Fakültesi, \\ Jeoloji Mühendisliği Bölümü, 17020 Çanakkale (e-posta: perincek@yahoo.com)
}

\section{ÖZ}

$\mathrm{Bu}$ çalışmanın amacı; Çetin Barajı'nın gölalanı çevresindeki yerleşim alanlarını tehdit edebilecek olası heyelanları tespit etmektir. Çetin Barajı Siirt'in Pervari ilçesi sınırları içerisinde yüksek eğimli yamaçların bulunduğu Botan Çayı (Ulu Çay) vadisine kurulmaktadır. Çetin Barajı aksı ve gölalanı allokton birimler üzerinde yer alır. Metamorfik birimlerin ekayları arasında Maden Karmaşığı bulunur. Bu birim heyelanların sebeplerinden biridir. Yamaç eğiminin çok yüksek olması heyelanların en önemli nedenidir. Bu nedene Maden Karmaşığı'nın varlığı da eklenince heyelan miktarı artmıştır. Heyelanı tetikleyecek ikinci bir neden ise depremlerdir. Botan Çayı vadisi boyunca yamaç eğiminin yüksek olmasının nedeni bölgeyi Orta Miyosen'den beri etkileyen tektonizmadır. Bölgenin devamlı yükseldiğini gösteren çok sayıda verilerden en önemlileri askıda bulunan eski nehir yatağının aşınma düzlükleri ve taraçalardır. Bunlar heyelanların göreceli yaşlarını anlamada önemli ipuçları verirler. Bölgenin yükselmesine paralel olarak nehir, yatağını derinleştirmektedir. Bu yükselme vadi yamaç eğiminin artmasına neden olmaktadır. Vadi yamaçlarının eğimi arttıkça eski heyelan döküntüsü içinde yeni, daha genç heyelanlar meydana gelmektedir. Heyelan oluşumunu takiben yamaç aşağıya akan malzemenin nehir yatağını karşı kıyı yönünde ötelediği birçok yerde gözlenmiştir. Botan Çayı vadisinin sol ve sağ sahilinde kurulu olan köylerin önemli bir kısmı eski heyelan malzemesi ve aşınma düzlüğü üzerinde kurulmuştur. Eski heyelan malzemesinin topuk veya ayak kısmından yüzeyleyen su buralarda bahçeciliğin gelişmesine neden olmuştur. Baraj gölü suyunun toplanmaya başlandığı ilk yıllarda su altında kalacak bu alanlarda toprak-kaya su doygunluğunun artmasına paralel olarak yeni heyelanlar olması beklenmektedir. Haritalanan heyelanlar göreceli yaşları dikkate alınarak 7 sınıfa ayrılmıştır. En yaşlı olan heyelan için 1, en genç olanı için 7 rakamları kullanılmıştır. 1, 2, 3, 4 ve 5 numaralı heyelanlar aktif olmayan fosil heyelanlardır. 6 ve 7 numaralı heyelanlar ise aktif heyelanlardır. Haritalanan heyelan tipleri yaş verileri dışında akma-kayma tipleri ve akan-kayan malzeme tipi dikkate alınarak sınıflandırılmıştır.

Anahtar sözcükler: Güneydoğu Anadolu, Heyelan, Siirt, taraça, tektonik yükselme, yamaç döküntüsü 


\section{ABSTRACT}

Purpose of this study is to locate the landslides that can threaten the settlement areas around the Çetin dam reservoir is situated in vicinities of Pervari town of Siirt city. The Çetin Dam is going to be constructed in Botan Çay1 (Ulu Çay) valley. The Çetin dam crest, reservoir areas are all located on allochthonous units. The Maden Complex is situated between the slices of the metamorphic rocks. Very steep inclination of the valley slopes are among the significant causes of the landslides. The frequency of the landslides increases when this feature is combined with the presence of the Maden Complex. Another reason triggering the landslides is the earthquakes. The reason why the slope inclination is steeper along Botan Çay1 River is the tectonism which affected the region since the Middle Miocene. Among the most important numerous data that shows that the region is uplifting continuously are elevated erosional surface of the old rivers and the terraces can be counted as evidence of uplifting. These features provide important evidences to understand the relative ages of the landslides. The uplifting causes an increase in slope inclination. As the inclination of the slopes increase, new and younger landslides occur in debris of the older landslides. It was observed in many places that the material sliding downslope following the occurrence of the landslide diverted the river bed in the opposite direction. Most of the villages established on both banks along the valley of Botan Çay 1 River are located on old landslide material, landslide debris and erosional surface. The water emerging from the toe and foot of the older landslide material has promoted the horticultural activities. In line with the increase in water saturation of the rock and soil beneath the reservoir after water holding in the dam, new landslides can be expected around the active landslide areas. Based on their relative ages, the landslides mapped were classified into 7 groups. The symbol «1» was used for the oldest landslide and similarly, «7» was used for the youngest one. The landslides with the numbers «1,2,3,4 and 5» are the inactive, fossil landslides. The landslides indicated with 6 and 7 are active landslides. The landslides also were grouped based on flowing-sliding types and flowing-sliding materials except for dating.

Keywords: Landslide, scree deposit, Siirt, Southeast Turkey, Tectonic uplift, terrace

\section{GíRIŞ}

Çalışmanın amacı; Siirt'in Pervari ilçesi sınırları içerisinde Botan Çayı (Ulu Çay) üzerinde yapımı planlanan Çetin Barajı'nın gölalanı çevresindeki yerleşim alanlarını tehdit edebilecek olası heyelanları tespit etmektir.

Siirt'in doğusunda kalan çalışma alanı (Şekil 1) yaklaşık 150 kilometre karelik bir alanı kaplamaktadır. Çetin Barajı rezervuar alanı içinde çok sayıda heyelan gözlenmiştir. Bölgedeki köylerden birinde 2010 yılından önce olan bir heyelan nedeniyle köyün yarısı başka bir alana taşınmıştır. Barajın yapılmasından sonra rezervuardaki su seviyesinin değişmesiyle ilgili olarak değişecekgözenekbasıncı duraysızbirortam yaratabilir. Heyelan oluşumu ile ilgili endişelere bilinçli bir cevap vermek ve ayrıca zarar azaltma önlemlerini belirlemek için rezervuar kıyılarının duraylılığının saptanması için jeoteknik çalışma yapılmasına gereksinim duyulmuştur. Nehir yatağ1 seviyesinden başlayarak, nehrin sağ ve sol sahilindeki tepelere kadar akaçlama ve rezervuar alanının tümü çalışılmıştır. Özellikle köy evlerinin olduğu alanlar, aynı zamanda tarım alanları ve yollar ile ilgili kaygı duyulmaktadır. Heyelanların rezervuar içinde oluşturacağı dalgaların yaratacağ 1 potansiyel tehlike sözkonusudur.

Ofiste mevcut jeolojik haritalar ve yayınlar kullanılarak saha ile ilgili bilgiler 
derlenmiş, takibinde arazi çalışması yapılmıştır. Detaylı haritalama ile potansiyel risk alanları tanımlanmıştır.

Heyelan tipleri; dairesel (rotasyonal) kayma, düzlemsel kayma, blok kayma, kaya düşmesi, kaya devrilmesi, yamaç döküntüsü (molozu) akması, yamaç döküntüsü (molozu) çı̆̆ı, toprak akması,çamurakması,krip, yanalyayılma ve karmaşık heyelanlar olarak sınıflanmaktadır (U.S. Geological Survey, 2009). Heyelan terimi kaya düşmesi, derin yamaç kayması, sı̆̆ yamaç döküntüsü akması gibi çeşitli zemin hareketlerini kapsar. Yamaçta biriken malzeme suya doygun hale gelince moloz akması ve çamur akması oluşturur. Çetin baraj alanında yüksek eğimli yamaç ortamında gravite heyelanların birinci nedenidir, ayrıca başka nedenler de sıralanabilir. Bunlar: 1-Nehirlerin yarattığı aşınma nedeniyle yamaç eğiminin artması, 2-Kaya ve topraktan oluşan yamaçlarda eriyen kar suları ve yoğun yağmurlar nedeniyle su doygunluğunun artması, 3-Deprem nedeniyle ortaya çıkan sarsıntının yamaçlarda yarattığı duraysızlık, büyüklüğü 4 ten fazla olan depremlerin heyelanları tetiklemesi, 4-Kar - yağmur yüklemesi, yamaçta kaya- toprakmoloz birikmesi, insan eliyle yapılan yapılar nedeniyle aşırı yüklenme ve buna bağlı olarak yamaçlarda yüke direncin azalması.

Yamaç eğiminin yüksek olduğu yerlerdeki tutturulmamış gevşek ya da çatlaklı malzeme heyelanların olmasina neden olabilir, bu tip alanların heyelan olasılığ yüksektir. Her ne kadar heyelana neden olan fiziksel sebepleri tümüyle ortadan kaldırmak mümkün olmasa da, jeolojik etüt, başarılı mühendislik çalışması, etkin zemin güçlendirmesi ve başarılı yönetim heyelanların azaltılmasını sağlayabilir.

\section{BÖLGESEL JEOLOJİ}

Hakkari-Siirt alanının jeoloji haritası TPAO jeologları tarafindan 1977-1978 y1llarında tamamlanmış ve bölgenin jeolojisi Perinçek (1990; 1980b) tarafından yayınlanmıştır. Şekil 1 Geç Kretase sonrası ve Orta-Geç Miyosen bindirmelerinin güney cephesini göstermektedir.

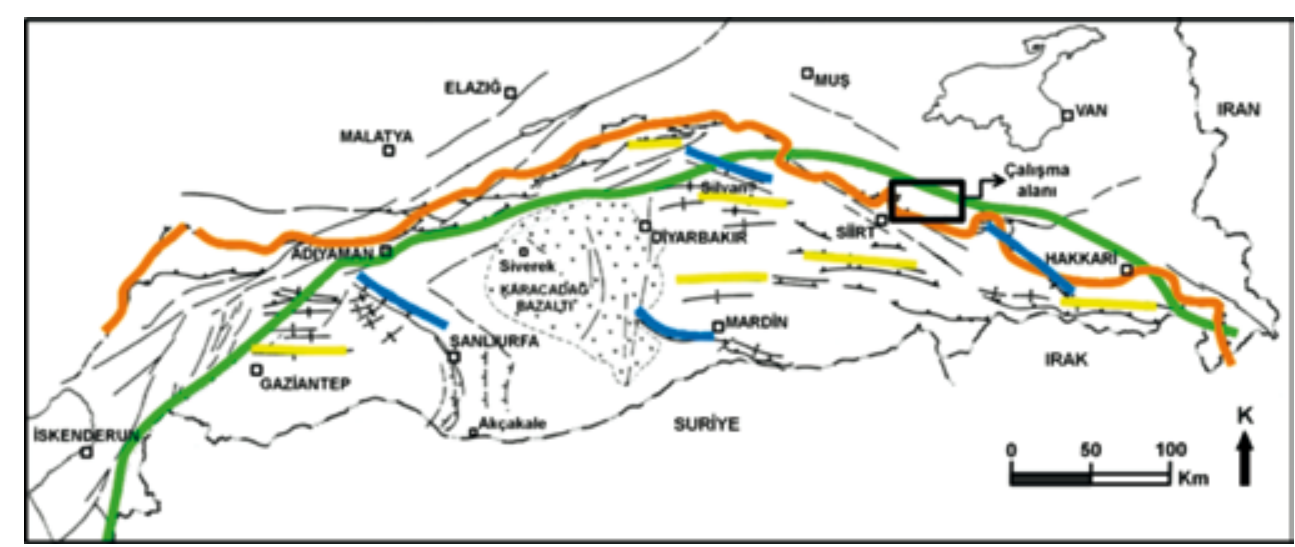

Şekil 1. Güneydoğu Anadolu'nun sadeleştirilmiş tektonik haritası. Yeşil çizgi: Geç Kretase bindirmesi, Turuncu renkli çizgi Orta-Geç Miyosen bindirmesi, Mavi çizgiler: Eosen öncesi yapısal hatları, Sarı çizgiler: Geç Miyosen yapısal hatları göstermektedir (Perinçek vd., 1987; Perinçek ve Çemen, 1990; Perinçek ve Çemen, 1992 basitleştirilerek alınmıştır).

Figure 1. Simplified tectonic map of the Southeast Anatolia. Green line: Late Ctretaceous thrust, Orange color line:Middle-Late Miocene thrust, Blue line: pre-Eocene structural trends, Yellow line: Late Miocene structural trends (simplified from Perinçek et al., 1987; Perinçek and Çemen 1990; Perinçek and Çemen 1992). 
Çalışma alanı ve dolayında bulunan allokton birimler Bitlis-Zagros bindirme kuşağına aittirler. Çetin Barajı aksı, gölalanı ve membamansap alanları allokton birimler üzerinde yer alır. Çalışma alanında genellikle metamorfik kayalar yüzeylenir. Metamorfik birimlerin ekayları arasında Alt-Orta Eosen yaşlı Maden Karmaşı̆̆ 1 bulunur. $\mathrm{Bu}$ birim çamurtaş1, pelajik kireçtaşı, volkanik, şeyl-kumtaşı ardalanmasından oluşur ve heyelanların sebeplerinden biridir. Çamurtaşı ve şeyl düzeyleri, birim suya doygun hale geldiğinde kayma düzlemi oluşturur ve üsteki metamorfik kayalar bu kayma düzlemleri boyunca vadi tabanı yönünde hareket ederek heyelanları oluşturmuştur.

Baraj dolayındaki diğer bir allokton birim, yer yer serpantinleşmiş olan ofiyolit topluluğudur. $\mathrm{Bu}$ birim aşırı tektonize olmuştur ve serpantinit düzeyleri heyelanların nedenidir. Guleman Grubu baraj alanının kuzeybatısında Belançay Köyü’nün batısında mostra verir. Birimin yüzlekleri göl alanına uzak olduğu için neden olduğu heyelanlar baraj için sorun çıkarmaz. Belençay Köyü dolayında Maden Karmaşığı ve Çüngüş Formasyonu'nun mostraları da vardır. Çüngüş Formasyonu Eosen Miyosen yaşlı kumtaşı-marn ardalanması ile temsil edilir. Bulunduğu alanlarda heyelan için uygun şartlar oluşturur. Birimin mostra verdiği alanlar baraj göl alanına uzak olduğundan oluşan heyelanlar baraj için sorun oluşturmamaktadır.

\section{Allokton Birimler:}

Allokton birimler; Çüngüş Formasyonu, Bitlis Metamorfitleri, Maden karmaşığı ve Guleman Grubu'ndan oluşur.

\section{Çüngüş Formasyonu (Tç)}

Geç Miyosen döneminde Güneydoğu Anadolu otokton istif üzerine bindiren allokton birimlerin en alt tektonik dilimini oluşturur. Bitlis Zagros zonunun en altındaki allokton birim olan Çüngüş Formasyonu aşırı derecede tektonize olmuştur, farklı litolojide bloklar içeren EosenMiyosen yaşlı, yeşil-gri renkli kumtaşı şeyl ardalanmasından oluşur (Sungurlu, 1974; Perinçek ve Özkaya, 1981; Perinçek, 1990; 1980a; 1980b). Tektonizma sonucu olarak bazı dayanımlı litoloji toplulukları bloklaşmış, şeyl düzeyleri ise matrikse dönüşmüştür (Şekil 2 ve 3). Kumtaşı düzeylerinde gözlenen sedimanter yapılar türbiditik akıntı ile çökelimi işaret eder. Lokal olarak çakıltaşı katkıları ve Maden Karmaşığına ait kireçtaşı ve volkanik blokları ve Guleman Grubuna ait ofiyolit blokları (olistolit) içerir. Birim napların öneyinde yer alan havzada yoğun tektonizma kontrolünde ekaylanarak yığışmış-birikmiştir. İçinde naplardan aktarılmıştaşınmış bloklar (ofiyolit, kireçtaşı vd) içerir. Bazı bloklardan (olistolit) Geç Kretase ve Erken-Orta Eosen yaşları alınmıştır. Birimin çökelme yaşı ise Eosen-Miyosen olarak kabul görmüştür (Perinçek ve Özkaya, 1981; Perinçek, 1990). Çüngüş Formasyonu Eosen-Miyosen otokton istifi üzerine bindirmiştir. Maden Karmaşı̆ğ, Guleman Grubu ve Bitlis Metamorfitleri ise tektonik dokanakla birim üzerinde yer alır (Şekil 3). Ayrıca birçok yerde Erken-Orta Eosen yaşlı karmaşığın (Maden Karmaşığı) metamorfik kayalardan oluşan naplar arasında yer alır. 


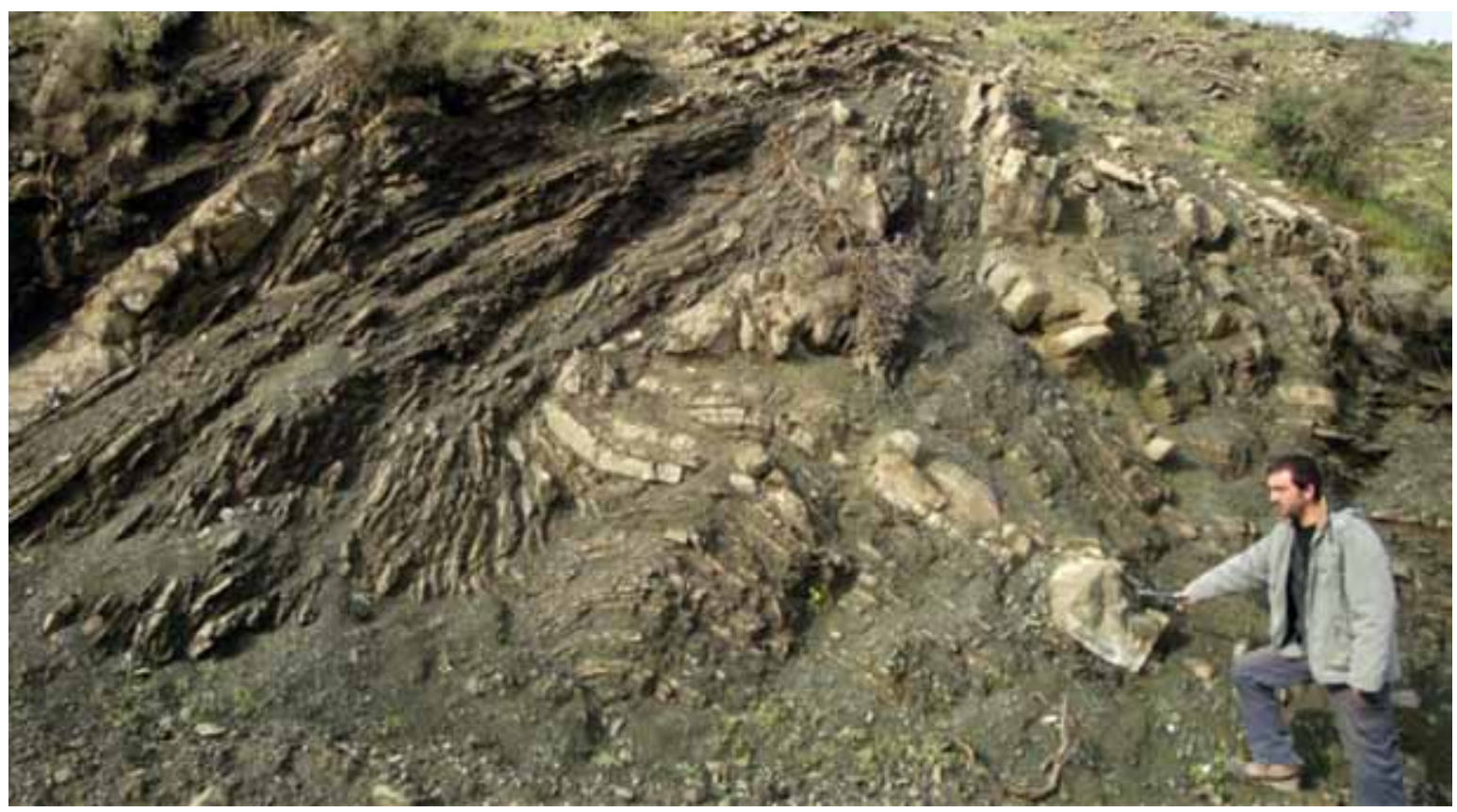

Şekil 2 Çüngüş Formasyonu'nun genel görünüşü. Birim aşırı derecede tektonize olmuştur. İçerdiği şeyl katkıları nedeniyle heyelan oluşumu için uygun ortam yaratır.

Figure 2. General view of the Çüngüş Formation. The unit is intensively tectonized. Because of the shale content it creates a suitable environment for landslide occurrence.

\section{Bitlis Metamorfitleri}

Bitlis Metamorfitleri (PzMzb) çalışma alanının kuzey ve kuzeydoğu kesiminde iki farklı tektonik dilim olarak mostra verir. Narsuyu-Dişlinar arasında; alt tektonik dilim (Bitlis Metamorfitleri; Mzb1) kristalize kireçtaşı ile temsil olunur. Aynı alanda üst (ikinci) tektonik dilim ise (Bitlis Metamorfitleri; PzMzb2) mikaşist, gnays, kuvarsit ve kristalize kireçtaşından oluşur (Perinçek, 1990; 1980b).

Bitlis Metamorfitleri (Mzb1-Pz,Mzb1): Bitlis Metamorfitleri'nin alt tektonik dilimi genellikle kristalize kireçtaşı ve daha az oranda dolotaşı ile temsil olunur. Bitlis Metamorfitleri otokton birimler ve allokton Çüngüş Formasyonu ve Maden Karmaşı̆̆ı üzerine bindirmiştir. Ayrıca Maden karmaşı̆̆ı açısal uyumsuzlukla Bitlis Metamorfitleri üzerinde çökelmiştir (Şekil 4).

Bitlis Metamorfitleri (P,Mz,b2): Bitlis Metamorfitlerine ait olan bu tektonik dilim mikaşist, kloritşist, fillat, kuvars-mikaşist, granatepidot şist, albit-epidot şist, gnays, kuvarsit, metakumtaşı, kristalize kireçtaşı ve kalkşistten oluşur. Beğendik Köyü dolayı ve doğusunda üst tektonik dilim Maden Karmaşığı ve serpantinleşmiş Guleman Grubu üzerine tektonik dokanakla gelir. 


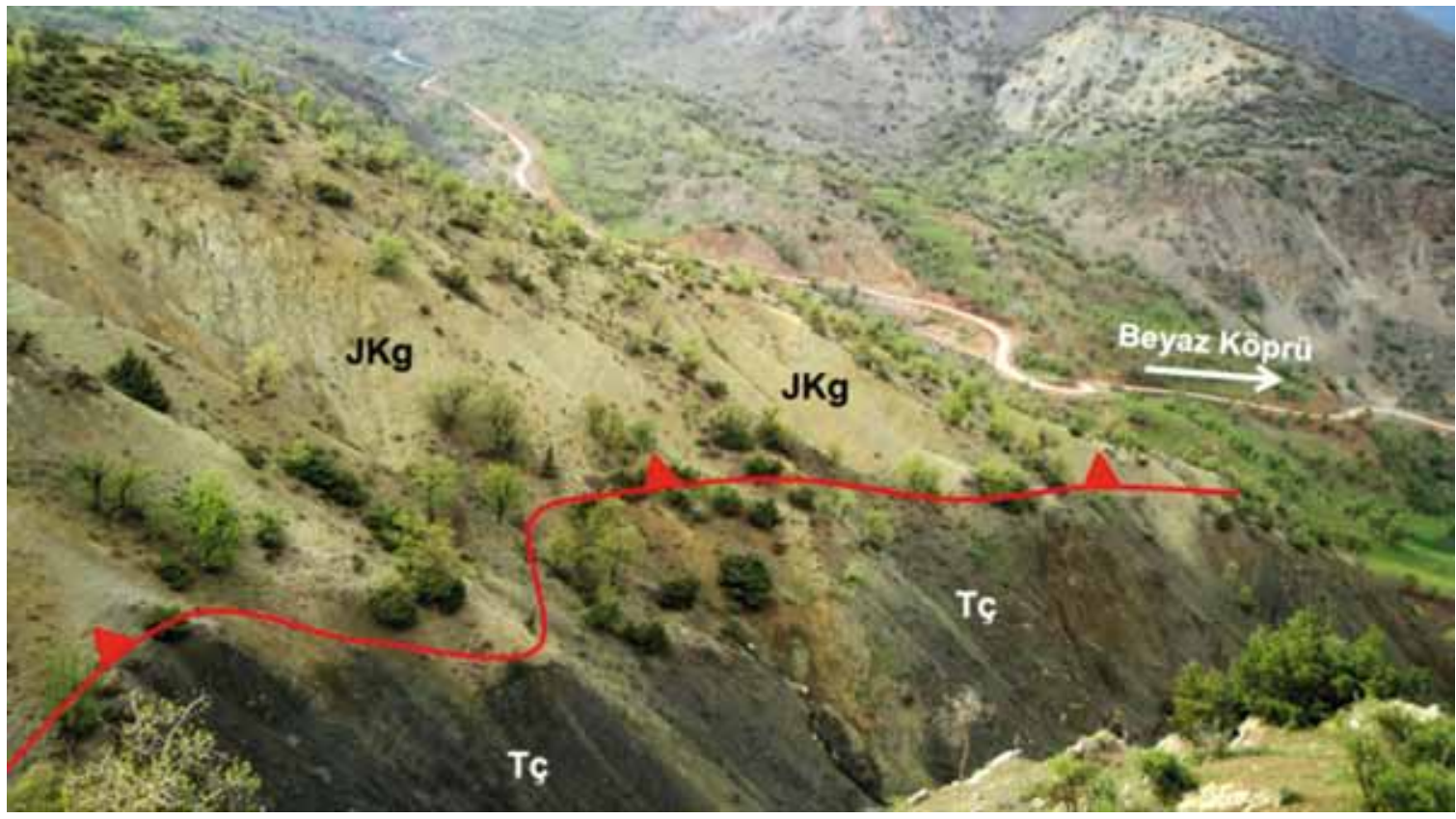

Şekil 3. Büyük Çay vadisi sağ sahilinde İncecik Mahallesi batısında Çüngüş Formasyonu ve bunun üzerine tektonik ilişkili gelen Guleman Grubu (JKg). Kırmızı çizgi bindirmedir.

Figure 3. View of the Çüngüş Formation (Ţ̧) on the eastern bank of Büyük Çay River valley and to the west of Incecik Settlement and the Guleman Group (JKg) which tectonically overlies the Çüngüs Formation.

\section{Maden Karmaşı̆̆ı (Tma)}

Birim çalışma alanının doğusunda Narlı Beldesi dolayında taban çakıltaşı ile Bitlis Metamorfitleri üzerinde yer alır. Kırmızı-gri renkli polijenik elemanlı çakıltaşı kötü boylanmıştır. İstif üste doğru Nummulitli gri kireçtaşı, kırmızı globorotalialı kireçtaşı ve daha üstte spilitik bazalta geçer. $\mathrm{Bu}$ litolojiler çalışma alanının birçok yerinde yukarıda belirtildiği gibi normal bir istiflenme sunarsa da, yanal yönde düzensiz ve devamsız olduğu yerler de vardır. Beyaz Köprü kuzeybatısında ise hakim litoloji bazalttır. Bölge genelinde birim killi kırmızı kireçtaşı, kırmızı çamurtaşı, gri kireçtaşı ve bazalt ile temsil olunur (Şekil 4 ve 5).

Bazı alanlarda Maden Karmaşı̆̆ (Tma) ve Guleman Grubu (JKg) ayrı ayrı haritalanamayacak şekilde tektonizma ile karışmışlardır. Bu karışma Bitlis Metamorfitleri'nin üst tektonik diliminin güneye Maden Karmaşı̆̆1 üzerine Orta Eosen sonrasında itilmesi sırasında olmuştur.

Maden Karmaşığı' nın üst sınırı her zaman bindirmeli, alt sınır ise bazı alanlarda lokal olarak tektonik ilişkilidir. $\mathrm{Bu}$ nedenle birimin kalınlığ yanal yönde oldukça değişkendir. Birim çalışma alanında Bitlis Metamorfitleri'nin alt dilimi üzerine açısal uyumsuzlukla gelir fakat bu ilişki metamorfitlerin üst diliminin Maden Karmaşı ğ üzerine itilmesi sırasında kısmen bozulmuştur. Pervari kazasının güneyinde Maden Karmaşığ güney yönünde itilerek otokton Tersiyer istifi üzerine bindirmiştir.

Maden Karmaşığının çökelme yaşı; gri renkli sığ deniz kireçtaşı ve kırmızı renkli pelajik kireçtaşında tanımlanan fosillere göre Erken-Orta Eosendir (Perinçek ve Özkaya, 1981; Perinçek, 1990; Perinçek, 1980a). 


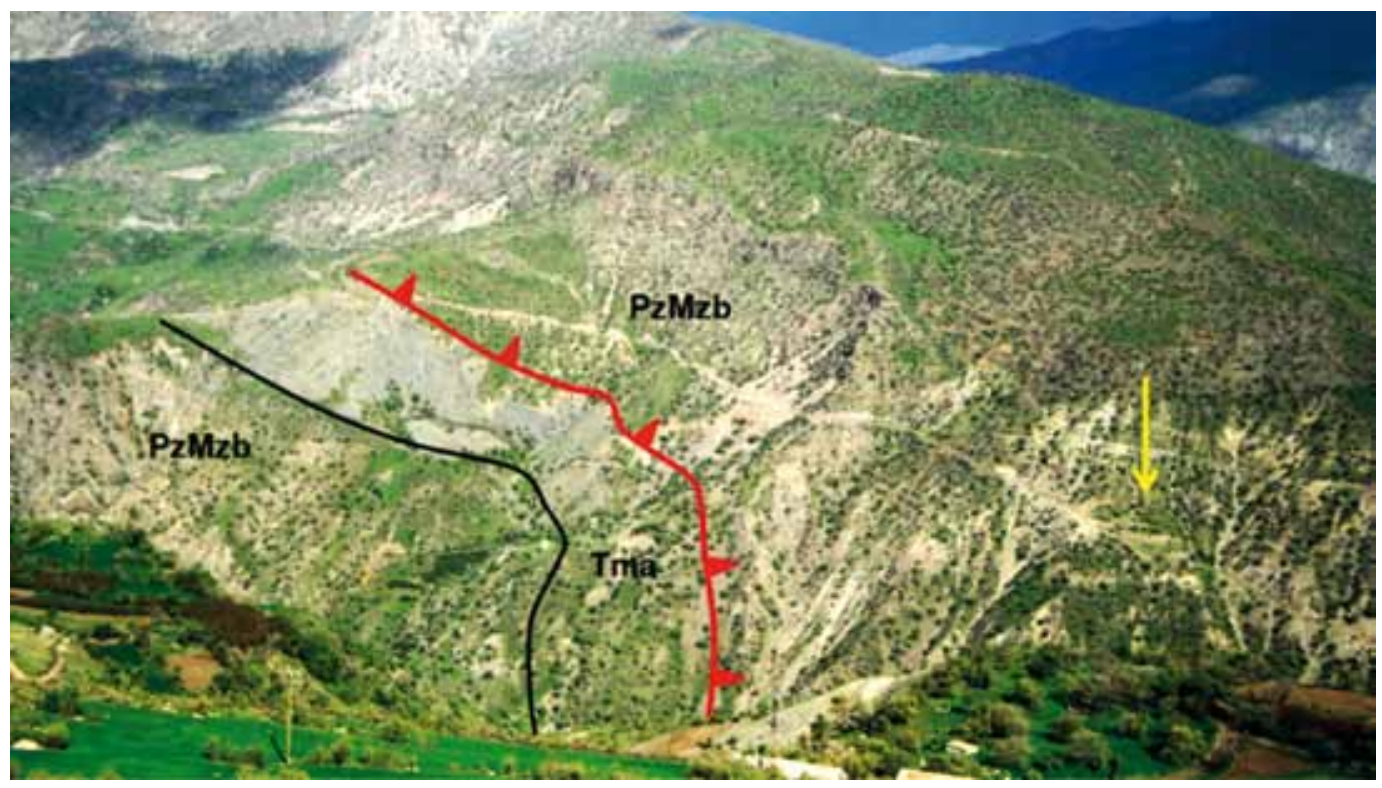

Şekil 4. Çukur Köyü yakınından (sol sahil) Yalkaya Köyü yönünde (sağ sahil) bakış. Maden Karmaşığı diskordanslı ilişkiyle alttaki Bitlis Metamorfitleri üzerindedir. Üst tektonik dilimi oluşturan metamorfik kayalar ise bindirmeli (kırmızı çizgi) ilişkiyle Maden Karmaşığı üzerinde yer alır. Baraj aksı sağ sahilde açılan sondajların yolları sarı ok ile işaretlenmiştir. Lokasyon için Şekil 11'e bakınız.

Figure 4. View from Çukur Village (left coast) to Yalkaya Village (right coast). Maden Complex unconformably overlies the Bitlis Metamorphics and the upper nappe slice of metamorphic rocks were thrusted onto the Maden Complex (thrust is marked with red line). The road to drilling sites on the right coast of the dam crest is marked with yellow arrow. For location; see Figure 11

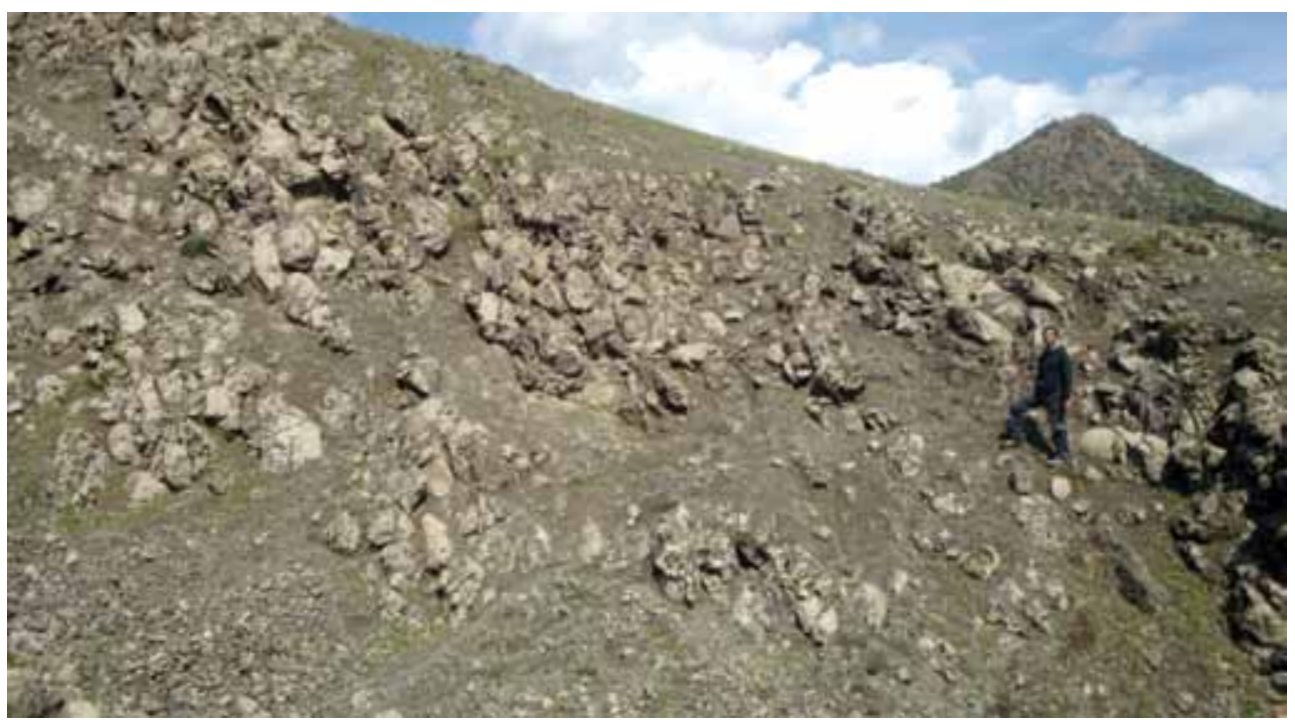

Şekil 5. Büyük Çay vadisi sağ sahilinde Darıcık Mahallesi batısında Maden Karmaşı̆̆ı’’nın (Tma) yastık lavlı volkanitleri. Lokasyon için Şekil 34 ve 39'a bakınız

Figure 5. Pillow lava volcanic rocks of the Maden Complex (Tma) on the right coast of Büyük Çay River valley and west of Darlclk Settlement. For location; see Figures 34 and 39 


\section{Guleman Grubu (JKg)}

Guleman Grubu (JKg) çalışma alanının kuzeybatısında Belançay yakınında mostra verir (Şekil 3). Bitlis kenet kuşağında, Guleman Grubu adı serpantinleşmiş ultramafik kayalar ve onlarla birlikte bulunan volkanik kayalar için kullanılmıştır. (Sungurlu, 1974; Perinçek, 1979; Perinçek ve Özkaya, 1981; Perinçek, 1990; Perinçek 1980a). Batıda Maden Kazası dolayında yaygın mostraları olan birimde hakim litolojiler; serpantinit, proksenit, dunit, harzburgit, gabro, diyabaz ve bazaltır. Birim çalışma alanında serpantinit ile temsil olunur (Şekil 6).

Guleman Grubu Geç Kretase döneminde kuzeyden güneye Bitlis Metamorfitleri üzerine naplar halinde bindirmiştir. Daha sonra Maden Karmaşı $\breve{g} 1$, metamorfitler ve Guleman Grubu üzerine çökelmiştir. Orta Eosenden sonra metamorfitlerden oluşan ikinci nap dilimi Maden Karmaşığı üzerine itilmiştir.

Çalışma alanında Guleman Grubu olarak haritalanan serpantinit mostraları için yaş verisi limitlidir. Sungurlu vd (1985) birim için JurasikKretase yaşını önermişlerdir.

\section{Tektonik}

Bölgenin yakın zaman tektoniğinin ana hatları: Türkiye, sismik aktivitenin etkin olduğu AlpHimalaya orojenik kuşağında yer alır. Anadolu'nun yakın zaman tektoniği levha ölçeğinde etkin tektonik deformasyon sonucu gelişmiştir (Şekil 1). Bindirme zonu Neo-Tetis okyanusunun güney kolunun kapanması sonucu Arap-Afrika ve Avrasya levhalarının K-G ve KD-GB yakınlaşması ile oluşmuştur. (Şengör ve Y1lmaz, 1981). İki levha arasındaki konverjant hareket Orta Geç Miyosende kıta kıta çarpışması ile sonuçlanmıştır. Türkiye ve çevresinin Neotektonik dönemi Bitlis-Zagros boyunca oluşan çarpışma ile başlar. Bölgedeki Neotektonik döneme ait yapılar, levha içi tektonik deformasyonun ürünüdür ve kıta-kıta çarpışma sonrasında olmuşlardır (Şengör, 1980). Anadolu, Paleotektonik dönemin sonunda, Neotektonik süreç başlarında kıtasal kısalmayla ilgili olarak, sıkışmalı tektonik rejim kontrolünde, yükselerek günümüzdeki yüksek plato morfolojisini kazanmış ve Anadolu'ya peneplen morfoloji hakim olmuştur. Arabistan-Afrika ve Avrasya kıtalarının

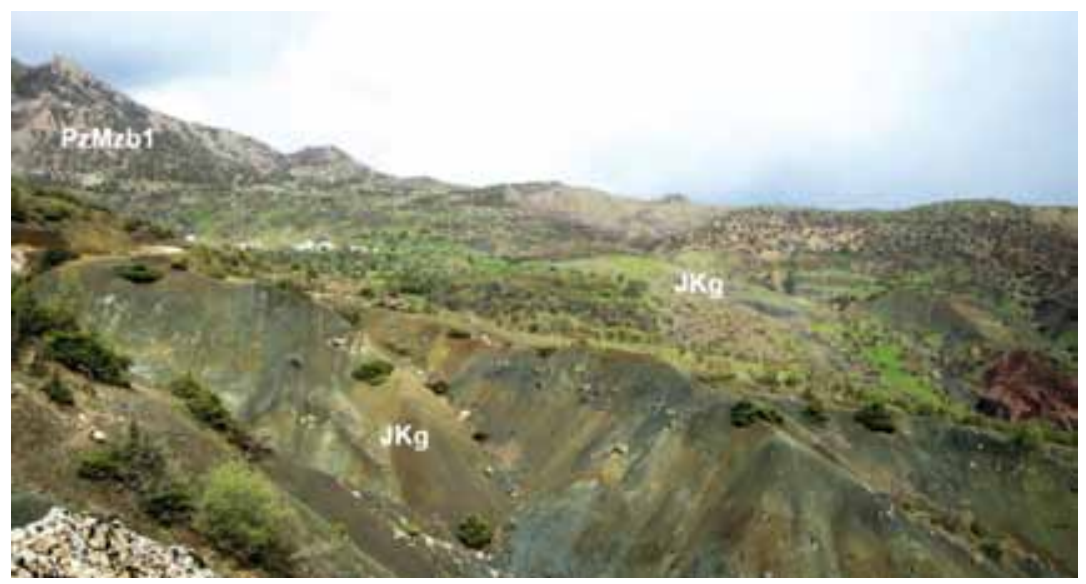

Şekil 6. Büyük Cay vadisi sağ sahilinde Darıcık Mahallesi güneybatısında Yedikapı Köyü dolayında Guleman Grubu (JKg) üzerine Bitlis Metamorfitleri’nin kristalize kireçtaşı (PzMzb1) bindirmeli ilişki ile gelir. Lokasyon için Şekil 34'e bakınız

Figure 6. Kristalized limestone of the Bitlis Matamorphics (PzMzb1) thrusted over the serpantinit of the Guleman Group (JKg) around Yedikapı Village to the southwest of Darıcı Settlement on the right coast of the Büyük Çay River valley. For location; see Figure 34 
çarpışması sonucu oluşan orojenik kuşak Türkiye sınırları içinde Bitlis Kenet Zonu olarak tanınır.

Arabistan kitasını kuzeyden sinırlayan Bitlis Kenet Kuşağı yapısal olarak güneye ilerleyen bindirmelerle temsil edilir. Güneydoğu Anadolu Bindirmesi, Kuzey Anadolu ve Doğu Anadolu Fayları ile birlikte Anadolu'nun Neotektonik yapısını şekillendiren mega-tektonik yapılarından biridir.

Tektonik olaylar: Arabistan Kıtası'nın kuzey kenarını oluşturan Güneydoğu Anadolu'da Paleotektonik dönemde Erken Kretase ile Orta Miyosen arasında üç önemli sıkışma rejimi yaşanmıştır. 1) Geç Kretase, 2) Erken Eosen öncesi, muhtemelen Geç Paleosen, 3) Orta Eosen sonrası muhtemelen Geç Eosen olarak tanımlanmıştır (Perinçek 1980a). Diğer taraftan, neotektonik dönemin Orta Miyosen de başlayan sıkışmalı tektonik rejim koşulları günümüzde de sürmektedir.

İlk paleotektonik evre Geç Kretase'de olmuş ve kuzeydeki Tetis Okyanusu'na ait malzemelerinin de dahil olduğu allokton birimlerin bindirmeler oluşturması ile sonuçlanmıştır. Aynı dönemde Guleman Grubunun ofiyolitik kayaları Bitlis Metamorfitleri üzerine bindirmiştir. $\mathrm{Bu}$ dönemde Arabistan kıtası üzerine yerleşen allokton birimler, kitanın kuzey kenarında yer alan Kampaniyen havzasını doldurmuştur. Şekil 1'de yeşil ile gösterilen hat Geç Kretase naplarının en güney cephesini oluşturur. Kampaniyen havzasının allokton birimlerle dolmasinı takiben Arabistan Kitası üzerinde güneyden kuzeye ilerleyerek başlayan Maastrihtiyen transgresyonu ile allokton birimleri mostra verdiği alanlar karasal ve denizel birimler tarafindan örtülmüştür.

Paleosen sonunda Arabistan Kitası'nın kuzeydoğu kenarını etkileyen yeni bir tektonik faz kıvrılma, yükselme ve aşınmaya neden olmuştur
(Perinçek, 1990; 1980a; Perinçek ve Çemen, 1992). Arabistan Kitası'nın kuzey kenarı KDGB yönlü sıkışmanın etkisinde kalmıştır. Eosen öncesi oluşan antiklinal eksenleri Şekil 1'de mavi çizgilerle gösterilmiştir. Güneydoğu Anadolu'nun kuzey ve doğusunda kıvrımlanmayı takiben yükselme ve önemli oranda aşınma olmuştur (Perinçek vd., 1992, Şekil 16). Kıvrılma ve aşınma evresinden sonra, Güneydoğu Anadolu'nun önemli bir bölümü Erken Eosen transgresyonu ile tekrar denizel ortam koşullarına dönmüştür (Perinçek, 1990; 1980a; Perinçek ve Çemen, 1992).

Erken-Orta Eosen döneminde,

Güneydoğu Anadolu'da transgresyon maksimum sınırlarına ulaşmış ve bölge tamamen sular altında kalmıştır (Perinçek vd., 1992). Bu dönemde kuzeyde temelini Bitlis Metamorfitleri ve Guleman Grubu'nun oluşturduğu faylarla kontrollü havzada Maden Karmaşığı çökelmiştir (Şengör ve Yılmaz, 1981). Eosen sonunda, Arabistan Kıtası'nın kuzey kenarı K-G sıkışmanın etkisinde kalmaya başlamış, Maden Havzası kapanmış, Maden Karmaşığı ve bununla birlikte havzanın tabanını oluşturan Bitlis Metamorfitleri ve Guleman Grubu naplar halinde güneye Çüngüş Havzası'nın olduğu alana itilmişlerdir. $\mathrm{Bu}$ tektonik olay etkisini Arabistan Kıtası üzerinde de göstermiş ve Geç Eosen döneminde Güneydoğu Anadolu'da regresyon başlamıştır. Geç EosenOligosen fasiyes haritasında, bu tektonik olay ve bunun etkisiyle gelişen regresyonun işaretleri belirgindir (Perinçek vd., 1992).

Miyosen tektonik olayların en etkin olduğu dönemdir, bu dönemde oluşan bindirmelerin genleri öncekilere göre daha büyük boyutlardadır. Söz konusu K-G sıkışma rejimi bölgede D-B doğrultulu yapıların gelişmesiyle sonuçlanmıştır. Şekil 1'de görülen turuncu renkli bindirme hatları ve sarı renkli D-B doğrultulu yapısal eksenler bu dönemin yapısal ürünleridir. 
Geç Miyosende Güneydoğu Anadolu'yu etkileyen sıkışma kuvvetleri öncelikle düşük açılı bindirmelere neden olmuş daha sonra doğrultu atımlı fayların gelişmesini sağlamıştır. Kenet kuşağına sub-paralel olarak uzanan Doğu Anadolu Fayı dışındaki faylar Arabistan Kıtası platformuna ait otokton istifinin olduğu alanda etkin olmuşlardır. Bu faylar kıta içi deformasyonla ilgili olup Doğu Anadolu Fayı'ndan farklıdırlar.

\section{ÇETINN BARAJI VE DOLAYINDAKİ KUVATERNER ÇÖKELLERİ VE HEYELANLARIN ÖZELLÍKLERİNIN TANIMLANMASI}

Kuvaterner çökellerinin dağılımı ve bölgede gözlenen heyelanlar iki alt başlıkta incelenmiştir. Bunlar aşağıda verilen başlıklar altında sunulacaktır.

1- Dişlinar, Çetin Baraj aksı ile Pervari arasında Botan Çayı (Ulu Çay) Vadisi boyunca gözlenen Kuvaterner çökelleri ve heyelanların genel özellikleri ve

2- Çetin Baraj aksı, İncecik Köyü, Beyaz Köprü arasında ve dolaylarında Büyük Çay Vadisi boyunca gözlenen Kuvaterner çökelleri ve heyelanların genel özellikleri.

Çetin Barajı, yüksek eğimli yamaçların bulunduğu Botan Çayı (Ulu Çay) Vadisine kurulmaktadır. Yamaç eğiminin çok yüksek olması heyelanların en önemli nedenidir. $\mathrm{Bu}$ nedene Maden Karmaşığı'nın varlığg da eklenince heyelan miktarı artmıştır. Pervari ile Çukur yerleşim alanları arasında sol sahilde heyelan çok sayıdadır. Bunun nedeni yamaç eğimi ve bu sahildeki Maden Karmaşığı mostralarıdır. Aynı alanda sağ sahilde sadece metamorfik kayalar yüzeylenir ve heyelan sayısı çok azdır. Çukur Köyü batısında her iki sahilde Bitlis Metamorfitleri ve Maden Karmaşı birlikte bulunur ve heyelan yoğunluğu sağ ve sol sahilde birbirine yakın sayıdadır.
Botan Çayı (Ulu Çay) Vadisi boyunca yamaç eğiminin yüksek olmasının nedeni bölgeyi Orta Miyosen'den beri etkileyen tektonizmadır. Güneydoğu Anadolu bindirme kuşağı Orta Miyosen ile günümüz arasında kuzey-güney yönünde sıkışmaktadır. Sıkışma şarıyaj, ters fay ve doğrultu atımlı faylarla karşılanmakta ve bölge devamlı yükselmektedir. Bölgenin devamlı yükseldiğini gösteren çok sayıda verilerden en önemlileri askıda bulunan eski nehir yatağı aşınma düzlükleri (Qte) ve taraçalardır (Qt). Çalışma alanında yapılan jeolojik haritalama sırasında aşınma düzlükleri-taraçalar da haritalanmıştır. Bunlar heyelanların göreceli yaşlarını anlamada önemli ipuçları verirler. Bölgenin tektonik yükselmesi aynı zamanda vadi yamaç eğiminin artmasına neden olmaktadır. Vadi yamaçlarının eğimi arttıkça eski heyelan döküntüsü içinde yeni, daha genç heyelanlar meydana gelmektedir. Bölge yükseldikçe nehir vadisini derinleştirmekte yamaçlardaki yamaç döküntüsü birikintilerinin, yamaçta yığışmış olan eski heyelan malzemesinin nehir kenarında bulunan mostraları, nehir sahili boyunca akarsu tarafından oyulmakta, yamaçta desteksiz kalan malzeme içinde yeni heyelanlar oluşmaktadır. Akarsu, kıyılarındaki eski heyelan topuklarını aşındırınca, topuktaki ağırlık kalkmakta, daha yukarı kotlarda yamaç dengesi bozulmakta ve buralarda yenilenen heyelanlar olmaktadır. Bunun yanında, baraj yapımından sonra göl oluşması nedeniyle akarsuyun oymaaşınma etkisi ortadan kalkacak, ya da önemli oranda azalacaktır. Böylece heyelan tetikleyen sebeplerden biri ortadan kalkacak, heyelan oluşumu bu açıdan kısmen azalacaktır. Baraj bitimini takiben, göl alanında birikecek su, göl kıyısında kalan malzemenin suya doygunluğunu artırarak kaymaya neden olması beklenmektedir.

Çetin barajı dolayında yapılan heyelan etüdü 3 aşamada gerçekleştirilmiştir. Önce 
büroda uydu görüntüleri ve 1/35000 ölçekli hava fotoğrafları kullanılarak heyelan alanları ve diğer Kuvaterner çökelleri ve bazı kaya birimlerinin sinırları 1/25000 ölçekli topografya haritasına arazide kontrol edilmek üzere çizilmiştir. Arazi çalışması sırasında tanımlanan heyelanlar ve diğer jeolojik bulgular doğrulanarak haritaya işlenmiştir (Şekil 7).

Haritalanan heyelanlar göreceli yaşları dikkate alınarak 7 sınıfa ayrılmıştır. En yaşlı olan heyelan için 1, en genç olanı için 7 rakamları kullanılmıştır. Haritalanan heyelanların çoğunda göreceli yaş değeri heyelanın yanına işaretlenmiştir. 1, 2, 3, 4 ve 5 numaralı heyelanlar aktif olmayan fosil heyelanlardir. 6 ve 7 ise aktif heyelanlardır.
2. Heyelan topuk malzemesi altında yer alan kayma düzleminin akarsu yatağından yüksekliği,

3. Heyelanın olduğu alanda heyelan sonrası oluşan düzlüğün konumu,

4. Heyelan malzemesinin aşınma ve vadi tabanına aktarılma miktarı,

5. Heyelan sonrası oluşan yamaç döküntüsüyamaç molozu ve alüvyon taraçası çökelleri ile alüvyon malzemesinin ilişkisi. Söz konusu bu çökellerin miktarı,

6. Heyelan malzemesinin yıkanma miktarı (aşı1rı yıkanma ve heyelan malzemesinin matriks kısmının taşınmış olması heyelanın yaşlı olduğunu göstermektedir),

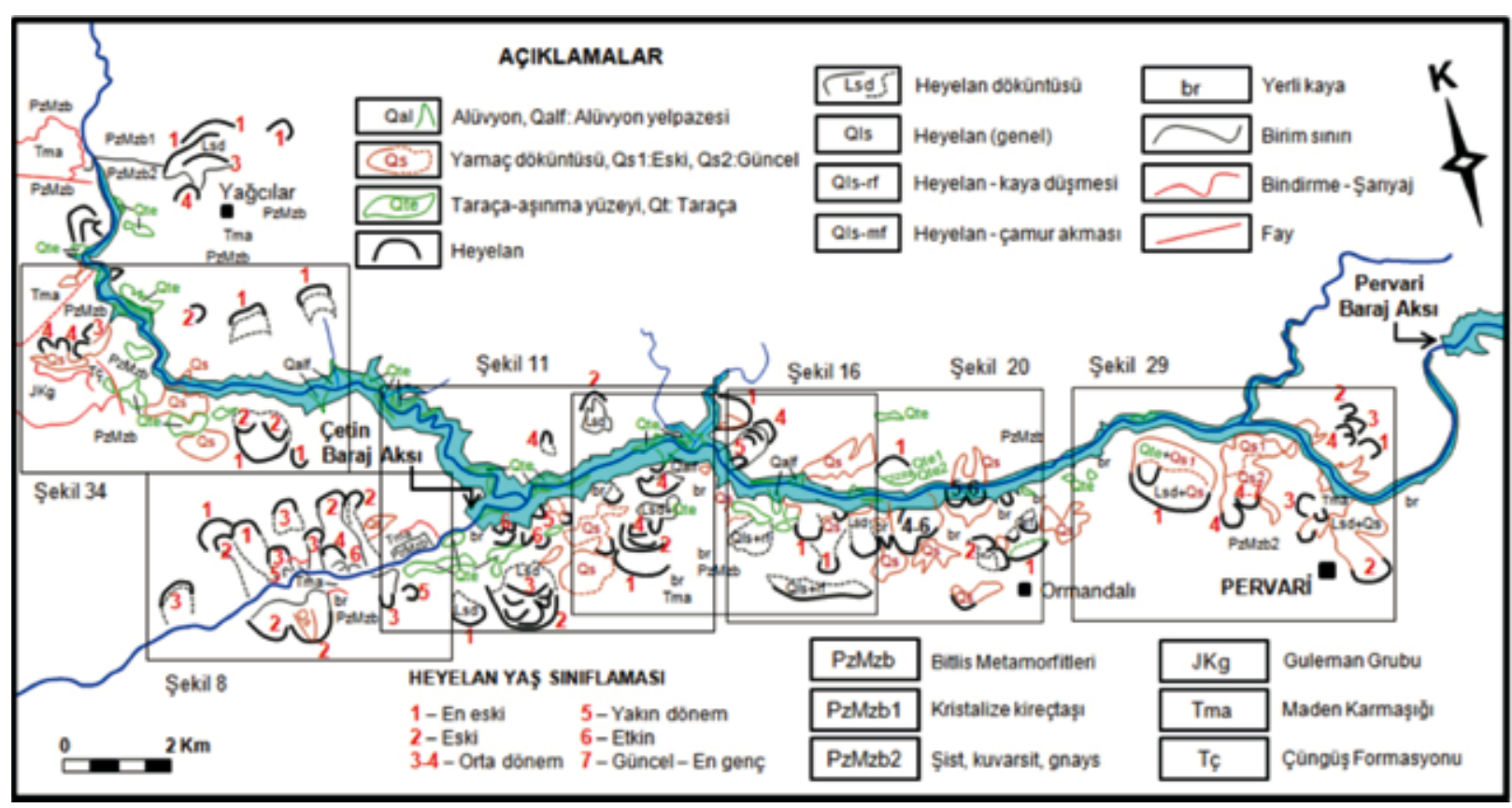

Şekil 7. Çetin Barajı ve dolayının heyelan, taraça, yamaç döküntüsü ve diğer Kuvaterner çökel haritası.

Figure 7. Landslide, terraces, scree and other Quaternary deposites map of Çetin Dam and surrounding area

Heyelanlara göreceli yaşlar verilirken aşağıdaki kriterler dikkate alınmıştır.

1. Heyelanın tümünün bugünkü nehir tabanından yüksekliği,
7. Heyelan malzemesi üzerinde gözlenen bitki örtüsü miktarı ve sıklığ1,

8. Heyelan alanındaki ağaçların konumu, topografya ile ilişkisi, heyelandan etkilenip 
etkilenmediği, hangi aşamada etkilendiği. Ağaçların heyelan sonrasında ve öncesinde büyüme miktarı,

9. Heyelan malzemesi üzerinde yerleşim olup olmadığı, varsa bu yerleşimin yaşının dikkate alınarak heyelanın yaşı hakkında yorumsal bilgi sunulmasi,

10. Heyelan tacını oluşturan kırılma düzlemindeki aşınma miktarı,

11. Heyelan topuğundaki malzemenin konumu, aşınma miktarı. Akarsu yatağını ötelediyse bunun miktarı ve ötelemenin korunma miktar1,

12. Heyelanlar iç içe ise birbiriyle ilişkisi (büyük heyelanlar içindeki küçük heyelanların çoğunlukla daha genç oldukları gözlenmiştir).

Bölgede gözlenen arkeolojik buluntular (artifacts) dikkate alındığında 1 numaralı heyelanın Milattan önceki bir döneme ait olduğu söylenebilir (Candan Kozanl1, Dr Rüstem Arslan; sözlü görüşme). Bu veri nedeniyle 1 ve belki de 2 numaralı heyelanların günümüzden 2-4 bin yıl beklide 5 bin yıl önce oluştuğu düşünülmektedir. 1 ve 2 numaralı heyelanların birçoğunun heyelan malzemesi önemli oranda aşındırılmıştır. Bunlar ve diğer fosil heyelanların bir kısmının kayma düzlemi (surface of rupture - surface of separation) aşınma nedeniyle görünür hale gelmiştir. 1 ve 2 numaralı heyelanların birçoğu bölgenin hılı yükselmesine paralel olarak askıdadır, topuk kısımları nehir tabanından çok yüksekte kalmıştır. 6 ve 7 numaralı heyelanlar ise aktif heyelanlardır. Bu gruptaki heyelanlar Gökçekoru Köyü kuzeybatısında, Gölgeli-Ayvalıbă̆ köyleri arasında, Ayvalıbağ Köyü kuzeyinde ve Narsuyu Köyü doğusunda haritalanmıştır. 7 numaralı heyelanlar günümüzde aktiftir ve bazıları 2010 yılı İlkbaharında eski heyelan malzemesinin tekrar hareket etmesiyle oluşmuştur. 6 ile tanımlanan heyelanlar ise yakın geçmişte aktif olmuş olan ve tekrar aktif hale gelme potansiyeli olan heyelanlardır. 6 ve 7 ile işaretli heyelanlar haritada kırmızı ile renklendirilmiştir. $\mathrm{Bu}$ alanlarda baraj gölünün su toplaması sırasında ve sonrasında kayadaki su doygunluğunun artması nedeniyle, ilk yıllarda heyelanlar oluşabilir..

Haritalanan heyelan tipleri yaş verileri dışında akma-kayma tipleri ve akan-kayan malzeme tipi dikkate alınarak sınıflandırılmıştır. Haritaya çizilen heyelanların (Q1s) önemli bir bölümünün rotasyonal veya düzlemsel kayma yüzeyi bulunmaktadır. Bunlar çalışma alanında çok yaygındır. Ayrıca kaya düşmesi (Qls-rf) ve çamur akması (Q1s-mf) olarak haritalanan heyelanlar vardır. Haritada heyelanların çoğu için benzer simge (Q1s) kullanılmıştır.

Heyelan oluşumunu takiben yamaç aşağıya akan malzemenin nehir yatağını karşı kıyı yönünde ötelediği birçok yerde gözlenmiştir.

Çalışma alanında taraça ve heyelanlar dışında yamaç döküntüsü - yamaç molozu (talusscree-slope wash) alanları da mümkün olduğunca jeoloji haritasına çizilmiştir. Yamaç döküntüsü gelişimi kısmen heyelan gelişimine paralel olarak oluşmaktadır. Heyelan sonrası heyelan taç alanında yaygın yamaç döküntüsü geliştiği görülür. Eski heyelanlar sonrası yer değiştiren baş, taç ve topuk malzemesi vadinin derinleşmesine paralel olarak daha aşağ 1 kotlara akarak yeni yamaç ve heyelan döküntüsünün oluşmasına neden olmuştur.

Botan Çayı vadisinin sol ve sağ sahilinde kurulu olan köylerin önemli bir kısmı eski heyelan malzemesi üzerinde kurulmuştur. Heyelan oluşumu sonrası oluşan düzlükler ve bu düzlükler dolayında gelişen aşınma yüzeyleri yerleşim için cazip alanlar haline gelmiştir. Heyelan malzemesinin topuk veya ayak kısmından yüzeyleyen su ise buralarda bahçe yapımını teşvik etmiştir. Bazı köyler ise sadece yamaç döküntüsü birikim alanları üzerine kurulmuştur. 
Çalışma alanında sol sahildeki Gölgeli Köyü kısmen terk edilmiştir. Terk nedeni bu köy yakınındaki heyelanlardır. Ayrıca Çetin Baraj aksının batısında sol sahilde kalan Üçoyuk Köyü'nde de terk edilmiş evler vardır.

\section{Dişlinar, Çetin Baraj aksı, Pervari arasında kalan Botan Çay Vadisi boyunca gözlenen Kuvaterner çökelleri ve heyelanların genel özellikleri}

$\mathrm{Bu}$ bölümde tartışılacak konunun jeolojik olay veya çökel türüne bakmadan söz konusu jeolojik bilgi mansap yönünden başlayıp memba yönüne doğru verilecektir.

Çalışma alanının en batısında haritalan heyelan Dişlinar Köyü batısındadır (sağ sahil) (Şekil 7 ve Şekil 8). Malzemesi önemli oranda aşındırılmış olan heyelanın göreceli yaşı 3 olarak tanımlanmıştır. Heyelan tacı $1100 \mathrm{~m}$ dolayındadır (Şekil 9).

Yalkaya Köyü kuzeybatısı ve kuzeydoğusunda göreceli yaşı 1 olan iki tane heyelan saptanmıştır. Bu heyelan taçları sırasıyla $1380 \mathrm{~m}$ ve $1310 \mathrm{~m}$ dolayındadır. Köy heyelandan sonra oluşan heyelanın baş kısmına yakın düzlük üzerine kurulmuştur. Aynı alanda gözlenen üçüncü heyelan diğer iki heyelana göre daha gençtir. Göreceli yaşı 2 olan bu heyelanın ve daha yaşlı olan diğer iki heyelanın malzemesi zaman içersinde yamaç aşağıya akarak heyelan döküntüsü (landslide debris) olarak çökelmiştir. Daha sonra heyelan döküntüsü üzerinde yamaç döküntüsü birikmiştir (Şekil 8).

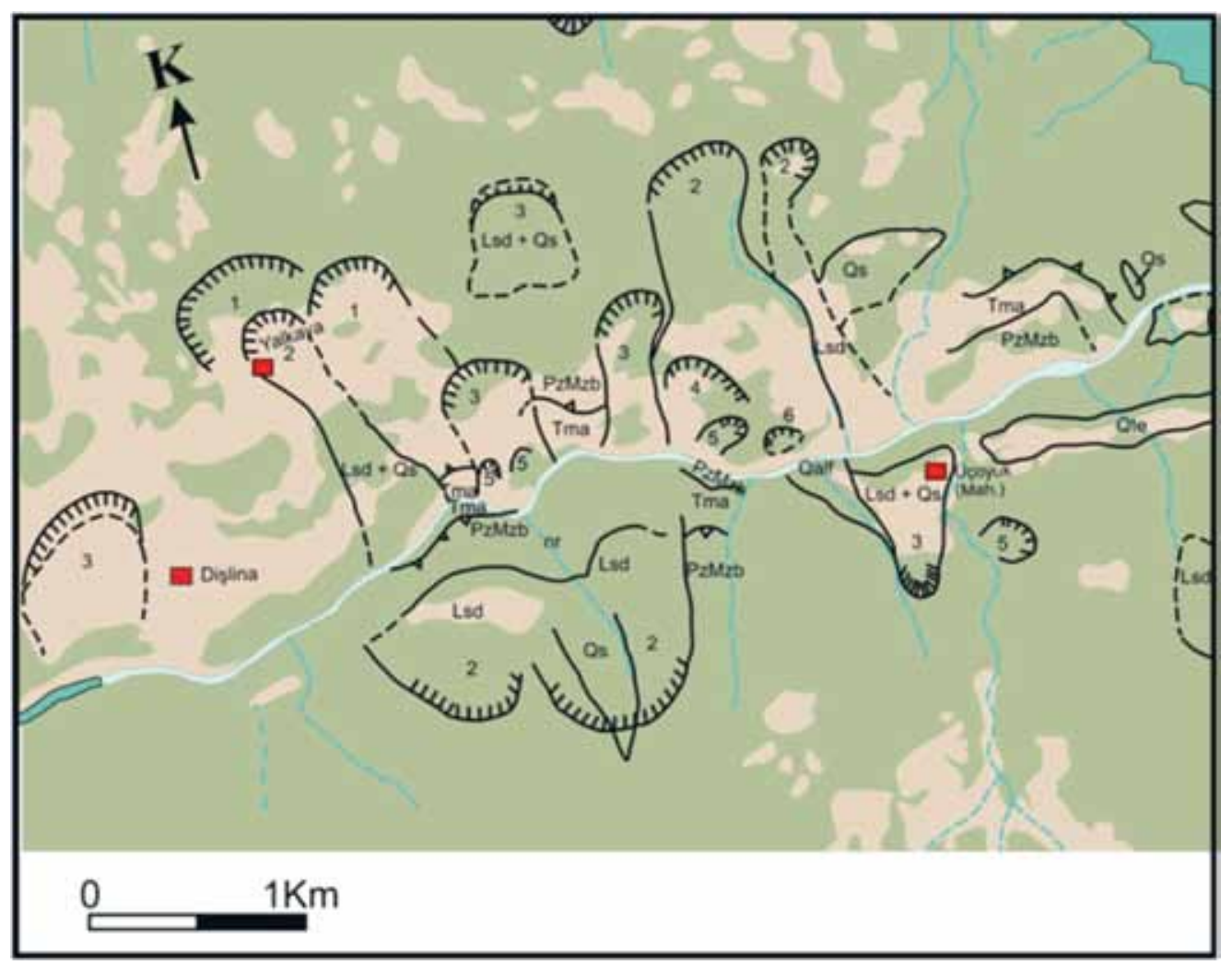

Şekil 8. Yalkaya-Arıca-Dişlinar-Üçoyuk dolayının heyelan haritası.

Figure 8. Landslide map of the Yalkaya-Arıca-Dişlinar-Üçoyuk area. 


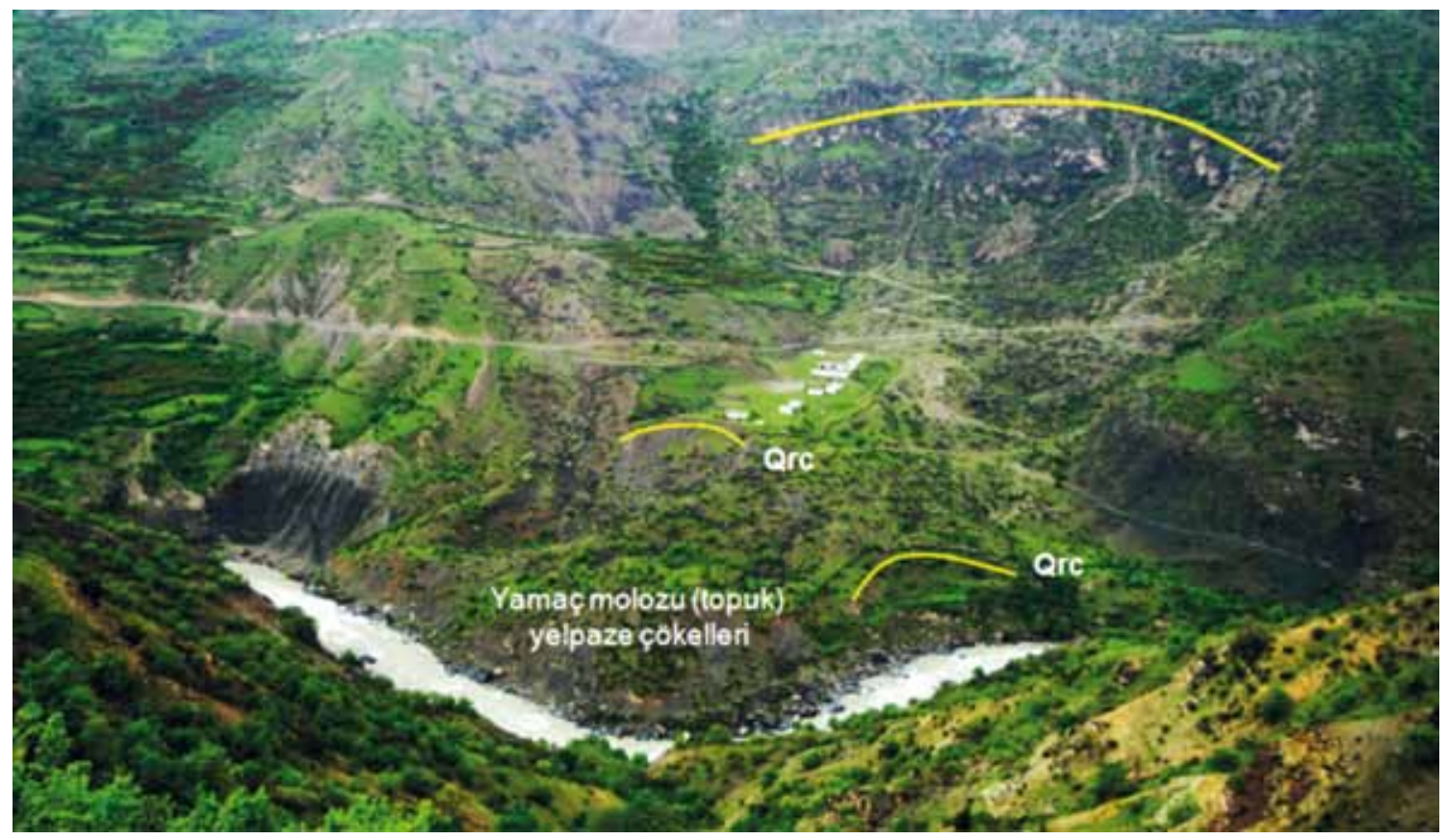

Şekil 9. Arıca Köyü (sol sahil) dolayından terk edilmiş EİEİ kampına (sağ sahil) bakış. EİEİ kampı heyelanın taç kısmından dönerek kayan heyelan malzemesi üzerinde kurulmuştur. Daha sonra kayan malzeme kısmen taşınmıştır. Qrc: Yeni heyelan. Lokasyon için Şekil 8'e bakınız.

Figure 9. View of deserted EIEI campus and surrounding area (right coast) from Artca Village (left coast). EIEI's Campus constructed on backward rotated surface (head). Later slide material partially removed. Qrc: recent sliding. For location; see Figure 8.

EİEI etüt kamp1 kuzeyinde gözlenen heyelan taci dolayından kopan heyelan malzemesi nehir yönünde kayarak kampın kurulduğu düzlüğü oluşturmuştur. Bu heyelanın göreceli yaşı 3 olarak yorumlanmıştır (Şekil 9). Söz konusu heyelan malzemesinin kapladığı alanda göreceli yaşı 5 olan ikincil heyelanlar gözlenmiştir. Söz konusu heyelanın doğu ve batısında Maden Karmaşığı mostra verir (Şekil 4). Heyelan malzemesinin döküntüsü altında da Maden Karmaşığı bulunur. Maden Karmaşı̆̆ heyelan için uygun kayma koşulları yaratmıştır. Karmaşık üzerindeki Bitlis Metamorfitleri Maden Karmaşığı'nın suya doyan çamurtaşı katkıları üzerinde yamaç aşağıya kaymıştır.

Terk edilmiş EİEİ kampı kuzeyinde de göreceli yaşı 2 olan metamorfitler üzerinde diğer bir heyelan saptanmıştır (Şekil 8). Bu heyelanın tac1 $1250 \mathrm{~m}$ dolayındadır. Heyelanın kayma düzlemi 1050 m yükseklikte ve askıdadır.

EİEİ kampının doğusunda $1250 \mathrm{~m}$ kotlarında göreceli yaşı 2 olan iki adet heyelan vardır. Bunların yanında $1275 \mathrm{~m}$ kotlarındaki diğer bir heyelanın göreceli yaşının ise 3 olduğu düşünülmektedir (Şekil 9). Şekil 8'de göreceli yaşı 2, 4 ve 5 olduğu düşünülen, birbiri içinde yer alan, üç tane heyelan görülmektedir. Üçoyuk Sırtı batısında görülen heyelan yakın zamandaki aktiviteleri nedeniyle Botan Çayı (Ulu Çay) yatağını ötelemiştir (Şekil 9). Nehrin sağ kıyısındaki eski ve yeni heyelan döküntüsü arasında alüvyon taraçası saptanmıştır (Şekil 10). 
Şekil 9'da görülen heyelanların olma nedeni heyelan malzemesinin altında kalan Maden Karmaşı̆̆ı'dır. Söz konusu Karmaşık, heyelanların batısında ve doğusunda mostra verir. Maden Karmaşığı baraj aksı yönünde nehir yatağına yaklaşır (Şekil 4) ve sol sahile geçer.

Sol sahilde Arıca Mahallesi güneyinde (Şekil 8) iki adet, göreceli yaşı 2 olan heyelan haritalanmıştır. $\mathrm{Bu}$ heyelanlar Botan Çayı (Ulu
Çay) yatağının bugünkü kotundan yaklaşık 150 m yüksekte aktığı dönemde olmuştur. Heyelan kayma düzlemi askıdadır ve nehir yatağından 150 $\mathrm{m}$ yüksektedir. Bu heyelanın da nedeni heyelan topuğunda mostra veren Maden Karmaşığı'nın çamurtaşı düzeyleridir. Arıca Mahallesi heyelan malzemesi - döküntüsü üzerinde kurulmuştur. Köyün güneydoğusunda heyelan taç alanını örten yamaç molozu - döküntüsü heyelanın göreceli yaşını anlamada veri olarak kullanılmıştır.

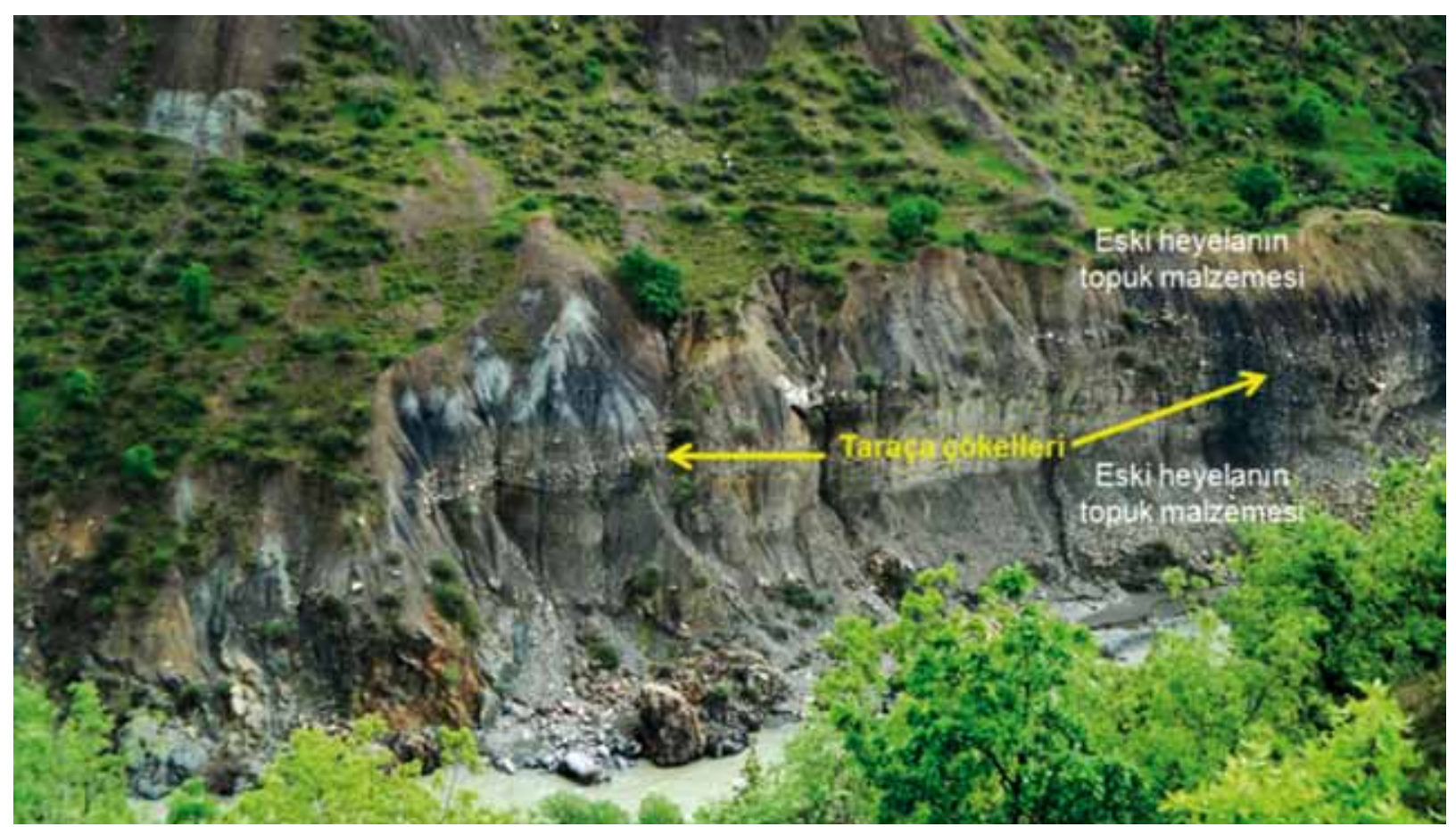

Şekil 10. Üçoyuk Köyü kuzeybatısında, sağ sahilde iki farklı yaştaki heyelan topuk döküntüsü malzemesinin yakından görünüşü. Alüvyon taraça çökelleri eski heyelanın topuk malzemesi üzerinde yeni kayan topuk malzemesinin altında yer alır. Lokasyon için Şekil 8'e bakınız.

Figure 10. Close view of two landslides toe debris (right coast). Alluvial terrace deposit overlies ancient toe debris and underlies recent toe debris. Location: northwest of Üçoyuk Village. For location; see Figure 8. 


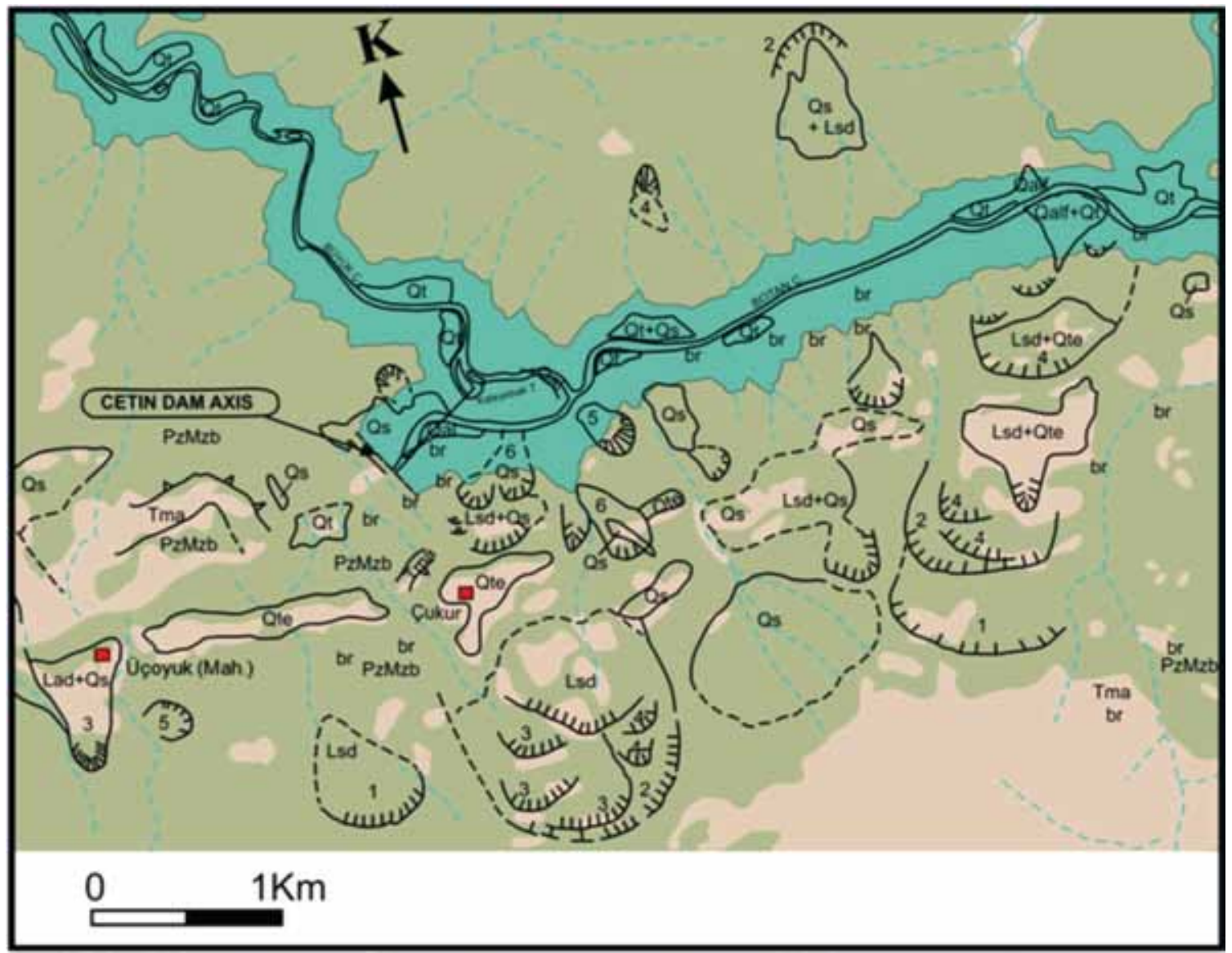

Şekil 11. Üçoyuk-Çukur-Gökbel dolayının heyelan haritası.

Figure 11. Landslide map of the Üçoyuk-Çukur-Gökbel area.

Üçoyuk Mahallesi (sol sahil) eski aşınma yüzeyi seki - taraça üzerinde kuruludur. Üçoyuk Mahallesi güneyinde göreceli yaşı 3 olan heyelan bulunur (Şekil 11). Bu heyelan alanından taşınan malzeme ve aynı alandaki yamaç döküntüsü kışın su taşıyan dereler kanalıyla Botan Çay vadi tabanına kadar ulaşan alüvyon yelpazesinin oluşmasına neden olmuştur. Mahalle dolayındaki eski seki-taraça doğu yönünde Çukur köyüne kadar kesikli olarak uzanır (Şekil 11).
Üçoyuk Mahallesi güneydoğusunda akma yönü açısından diğer heyelanlardan farklı olan bir heyelan haritalanmıştır (Şekil 12). Bunun göreceli yaş1 5 olup heyelan malzemesinin oluşturduğu döküntünün tekrar kaydığı ve daha genç heyelanlar oluşturduğu görülür. İkincil heyelanların ölçeği 1/25000 ölçekli haritaya çizilemeyecek kadar küçüktür. Söz konusu heyelan Botan Çay vadisi yönünde güneye değil bu vadiye doğru uzanan yan dere üzerindedir, doğudan batıya akmıştır. 


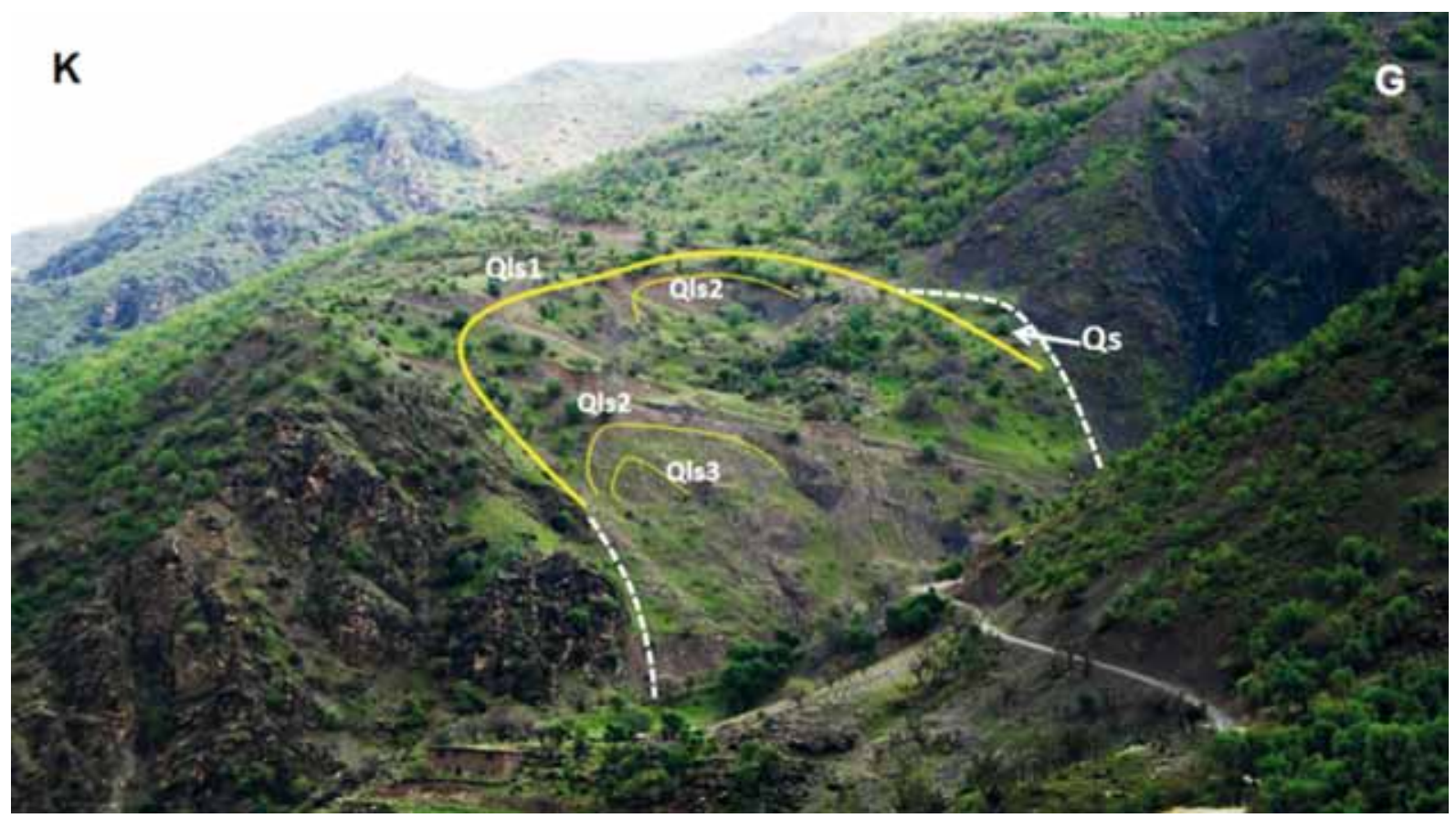

Şekil 12. Ü̈çoyuk Mahallesi güneydoğusunda heyelan $(\mathrm{Q} l s 1)$ ve heyelan malzemesi üzerine gelişen yamaç döküntüsü (talus) çökelleri (Qs). Qls2 ve Qls3 daha genç ikincil heyelanlardır. Lokasyon için Şekil 8'e bakınız.

Figure 12. Landslide (Qls1) in southwest of Üçoyuk Settlement and talus sediments (Qs) developed on the landslide material. Qls2 and Qls3 are younger, secondary landslides. For location; see Figure 8.

Çukur Köyü eski bir seki (taraçaaşınma yüzeyi) üzerinde kurulmuştur (Şekil 11). $\mathrm{Bu}$ alanda bulunan heyelanların oluşturduğu düzensiz topografya belirgindir. Köyün güneygüneydoğusunda iç içe heyelanlar görülür. Göreceli yaşı 3 olarak yorumlanan heyelan alanı içinde daha genç heyelanlar tespit edilmiştir. Genç heyelanların dört tanesinin göreceli yaşının 3, iki tanesinin ise 4 olduğu düşünülmektedir (Şekil 11).

Çukur Köyü kuzeydoğusunda haritalanan heyelanların nedeni köyün kuzeybatısında mostra veren Maden Karmaşı̆̆ıdır. Maden Karmaşığı doğu yönünde heyelan malzemesi döküntüsü tarafindan örtülür. Şekil 13'te görülen heyelan malzemesi üzerinde yamaç döküntüsü gelişmiştir. $\mathrm{Bu}$ alandaki heyelanın göreceli yaşı 5 olarak tanımlanmıştır. Aynı alanda 6 göreceli yaşlı küçük heyelanlar da bulunur. Bunlar 1/25000 ölçekli haritaya çizilemeyecek boyuttadır. Şekil 13'te görülen heyelanın topuk kısmında göreceli yaşı 6 olan iki heyelan daha vardır. Bunların topuk kısımları kısmen baraj göl alanında kalacaktır. Fakat heyelanların topuk alanında yerli kaya olduğundan dolayı bu iki heyelanın sorun çıkarması beklenmemektedir. 


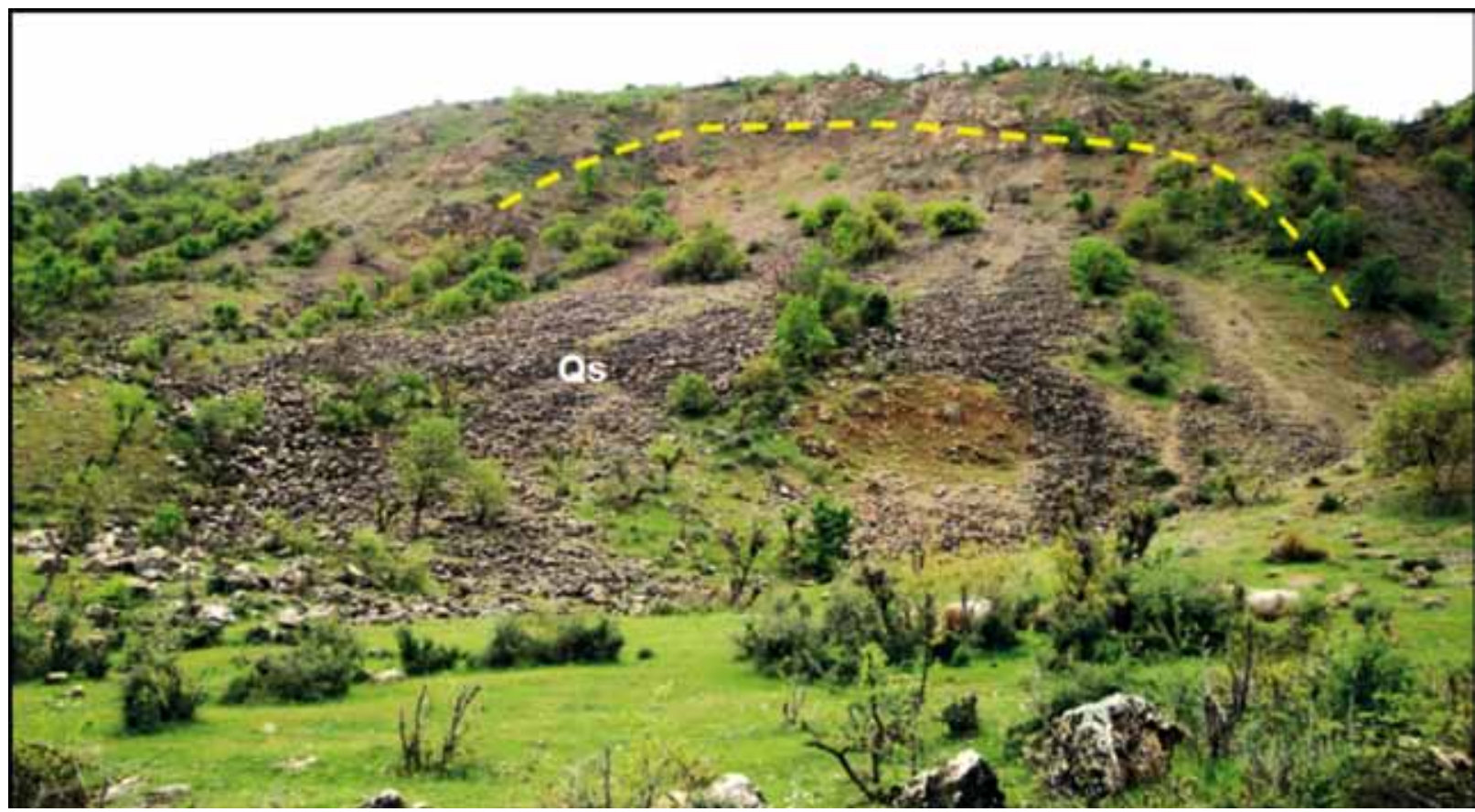

Şekil 13. Çukur Köyü kuzeydoğusunda, sol sahilinde (göl sahası dışında) heyelan malzemesi üzerinde gelişen yamaç döküntüsü (molozu) çökelleri (Qs). Lokasyon için Şekil 11'e bakınız.

Figure 13. Scree-talus sediments $(Q s)$. developed on the landslide material on the left coast (outside the reservoir area) to the northeast of the Çukur Village. For location; see Figure 11.

Çetin Baraj aksı yakın doğusunda Büyük Çay Botan Çay’ına kavuşur (Şekil 11). Kavuşma noktasının hemen doğusunda farklı yaşta iki alüvyon taraçası gözlenmiştir (Şekil 14). Baraj aksının sağ sahilde oturacağı alanda yamaç döküntüsü oldukça yaygındır (Şekil 11).

Gökbel Mahallesi eski aşınma düzlüğüseki (taraça) ve heyelan malzemesi üzerinde kurulmuştur (Şekil 15) Mahallenin bulunduğu alanda güney ve güneydoğudaki heyelanlardan gelen heyelan malzemesi de vardır.

Gökbel yerleşim alanının güneybatısında farklı yaşlarda heyelanlar güneybatıdan kuzeydoğuya gençleşerek sıralanır (Şekil 7). Bu heyelanların göreceli yaşları 1, 2 ve 4 olduğu düşünülmektedir. Bu heyelanlar dolayında yamaç döküntüsü birikimleri de oldukça yaygındır. Mahallenin kuzeyinde göreceli yaşı 4 olan bir heyelan ve heyelan malzemesi üzerinde yamaç döküntüsü birikimi haritalanmıştır. Söz konusu heyelan ve yamaç döküntüsü malzemesi yan dereler kanalıyla kuzey yönünde taşınarak Botan Çayı yatağına yakın alanda alüvyon yelpazesi oluşturmuştur. 


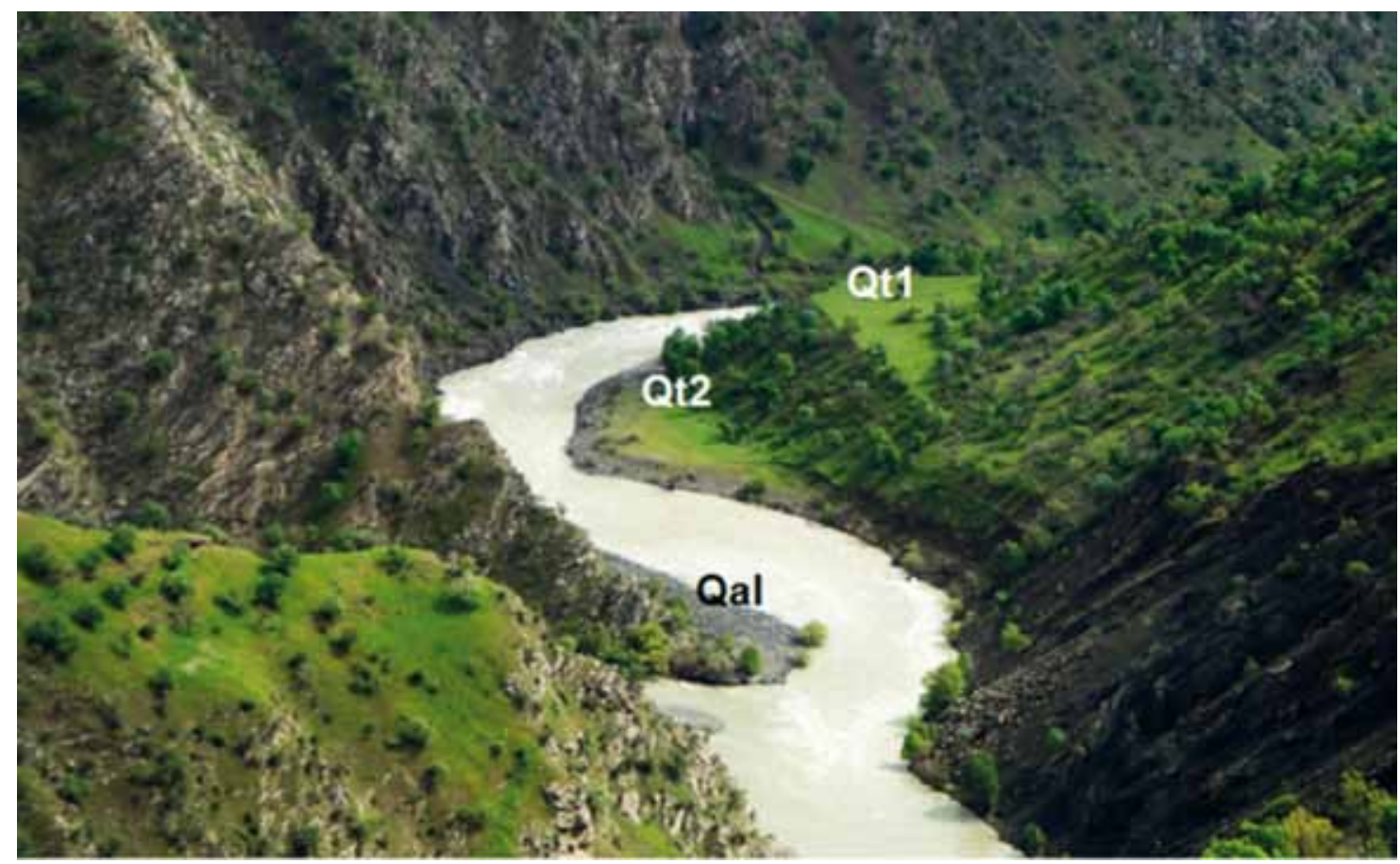

Şekil 14. Çukur Köyü kuzeyinden Botan Çay vadisine memba yönünde bakış. Qt1, Qt2: Alüvyon taraçası, Qal: alüvyon. Lokasyon için Şekil 11'e bakınız.

Figure 14. View from north of Çukur Village to the Botan Çay River valley, in upstream direction. Qt1, Qt2: Alluvial terrace, Qal: alluvium. For location; see Figure 11.

\section{G}

$\mathrm{K}$

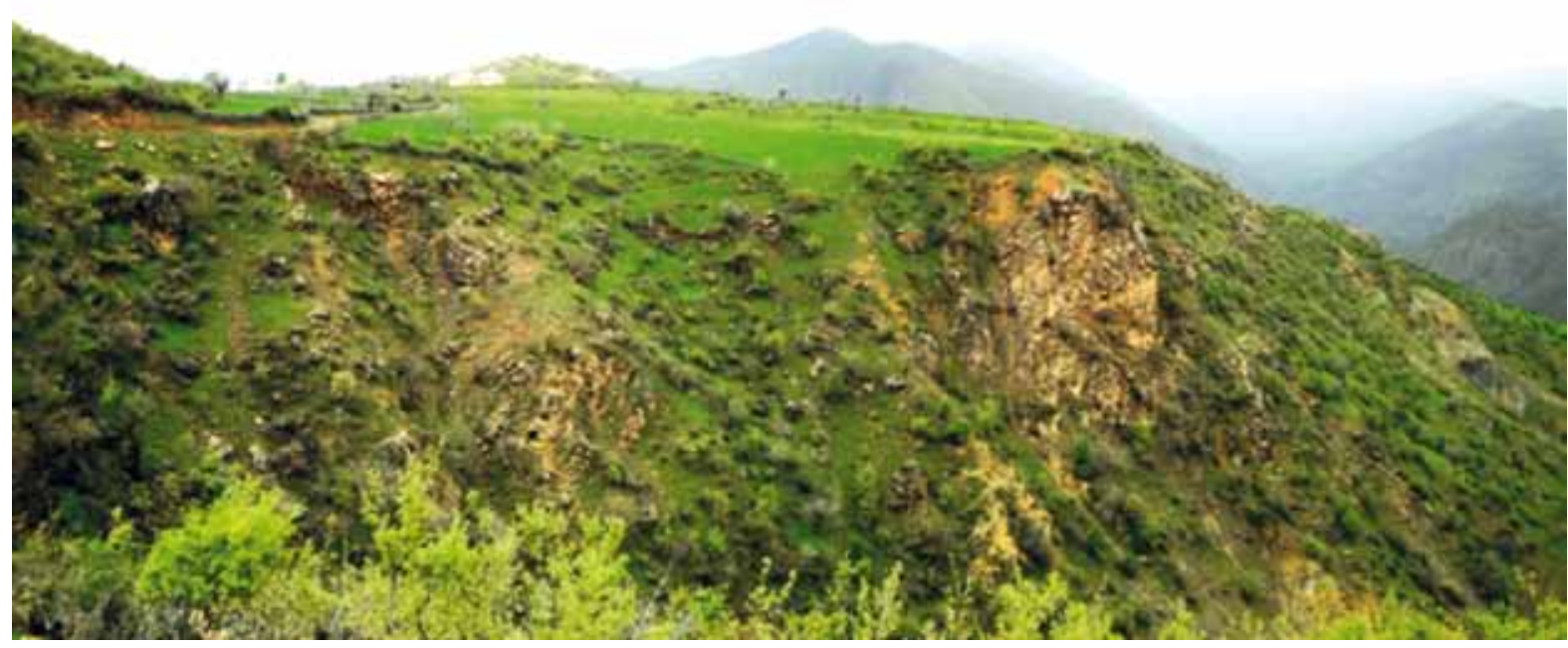

Şekil 15. Gökbel Mahallesine doğudan bakış. Eski heyelanın oluşturduğu morfolojik düzlük ve aşınma yüzeyi (taraça) üzerine kurulmuş bir yerleşim merkezi. Lokasyon için Şekil 11'e bakınız.

Figure 15. View from east to Gökbel Settlement. A settlement area established on the morphologically flat area formed by an older landslide material and old erosional surface (terrace). For location; see Figure 11. 


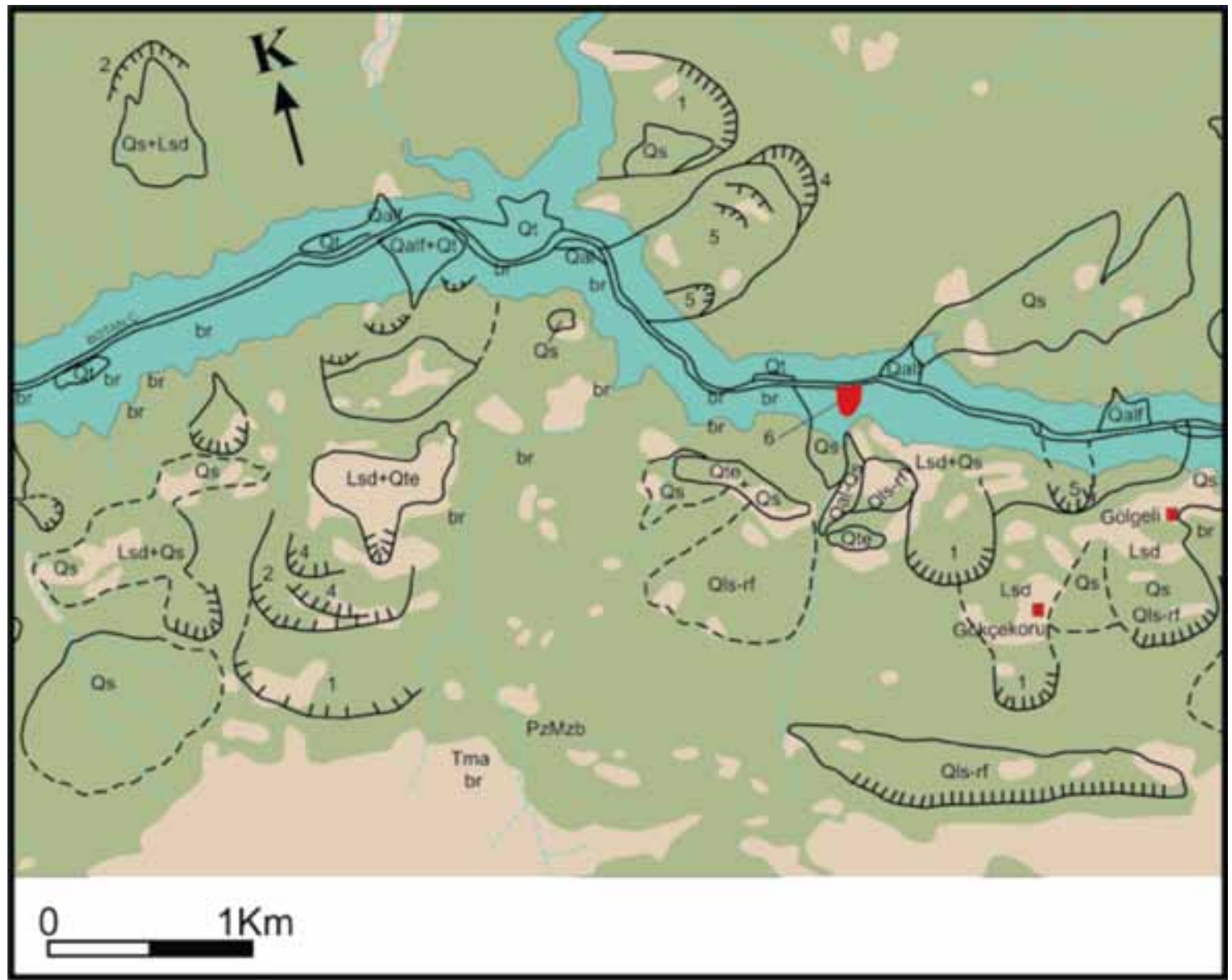

Şekil 16. Gökbel-Gökçekoru-Gölgeli dolayının heyelan haritası.

Figure 16. Landslide map of the Gökbel-Gökçekoru-Gölgeli area.

Gökbel Mahallesi kuzey ve kuzeydoğusunda sol sahilde göreceli yaşları 1, 2, 4 ve 5 olan heyelanlar görülür. Şekil 17'deki fotoğrafın sağındaki heyelan Botan Çayı sol sahilinde görülen en büyük heyelandır. Heyelanın göreceli yaşı 4 olarak tanımlanmıştır. Heyelanın taç kısmı 1300 m dolayındadır. Bu heyelanın topuk kısmı Botan Çay vadi tabanına kadar ulaşır. Taç kısmı 1300 m dolayında olmasına karşın topuğun güncel nehir yatağına kadar ulaşması nedeniyle heyelan için göreceli yaş 4 verilmiştir. Söz konusu heyelan alanı içinde göreceli yaşı 5 olan iki heyelan daha vardır (Şekil 16). Bu heyelanlar baraj bittikten ve gölalanı oluştuktan sonra dikkatle izlenmelidir. Sözkonusu eski heyelanların topuk kısmı gölalanı içinde kalacağı için buradaki eski heyelan malzemesinin suya doygunluğu artacaktır. Bu durumda heyelanda yeni bir hareket beklenebilir. Şekil 17'nin sol kısmında ise göreceli yaşı 1 olan eski bir heyelanın taç kısmı görülmektedir.

Gökçekoru dolayında göreceli yaş1 1 olan üç tane heyelan görülür. Bunlardan en güneydeki kaya düşmesi olarak gelişmiştir. Ayrıca aynı alanda yamaç döküntüsü (talus), heyelan döküntüsü, kaya akması ve taraça çökelleri de yaygındır (Şekil 16). 


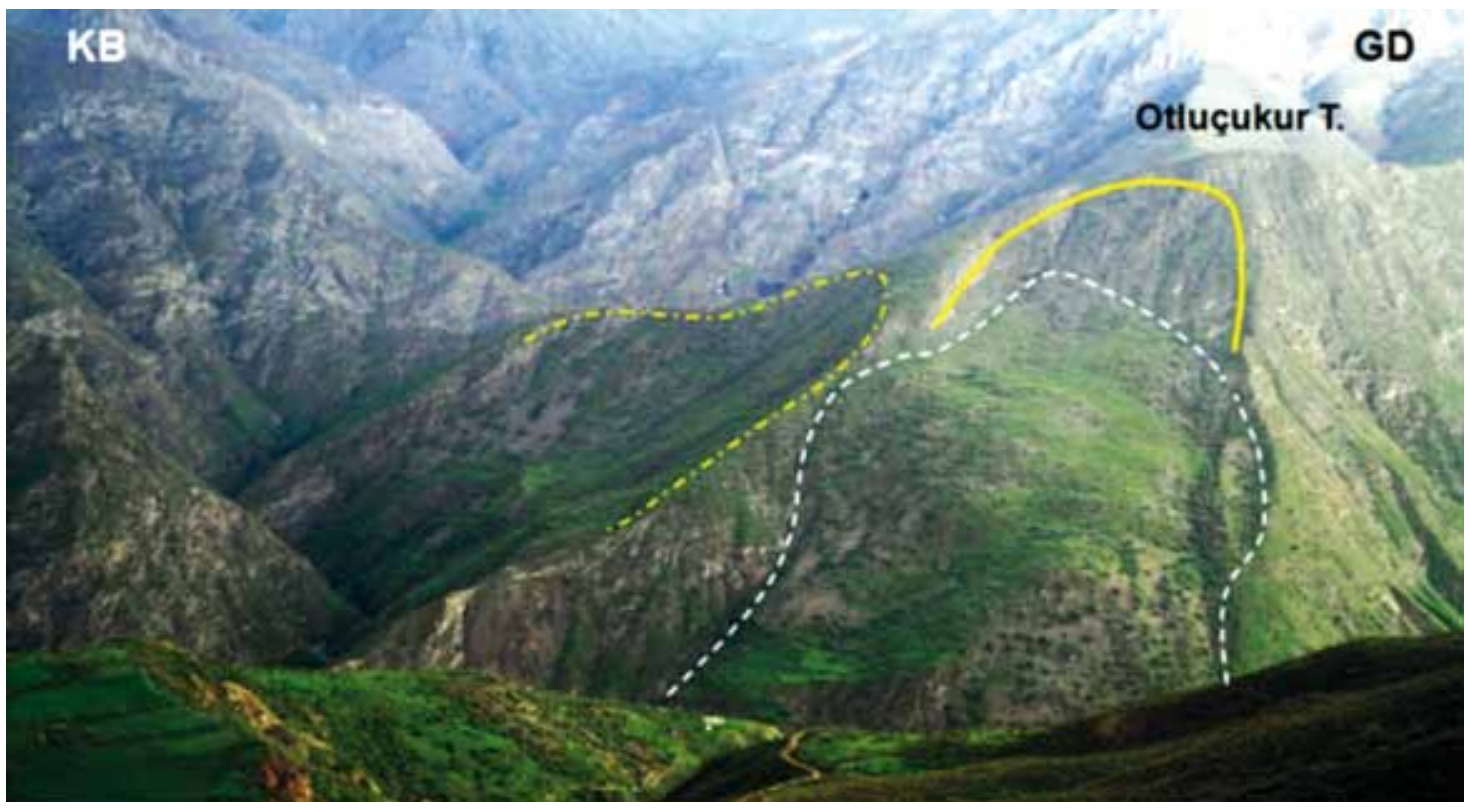

Şekil 17. Gökbel Mahallesi kuzeydoğusunda, sağ sahildeki en büyük heyelan (fotoğrafın sağında). Fotoğrafın solunda ise göreceli yaş1 1 kabul edilen eski bir heyelan görülmektedir. Lokasyon için Şekil 16'ya bakınız.

Figure 17. The largest landslide on the right coast, northeast of Gökbel Settlement (right side of the photo). On the left side of the photo, an old landslide (relative age 1) is observed. For location; see Figure 16.

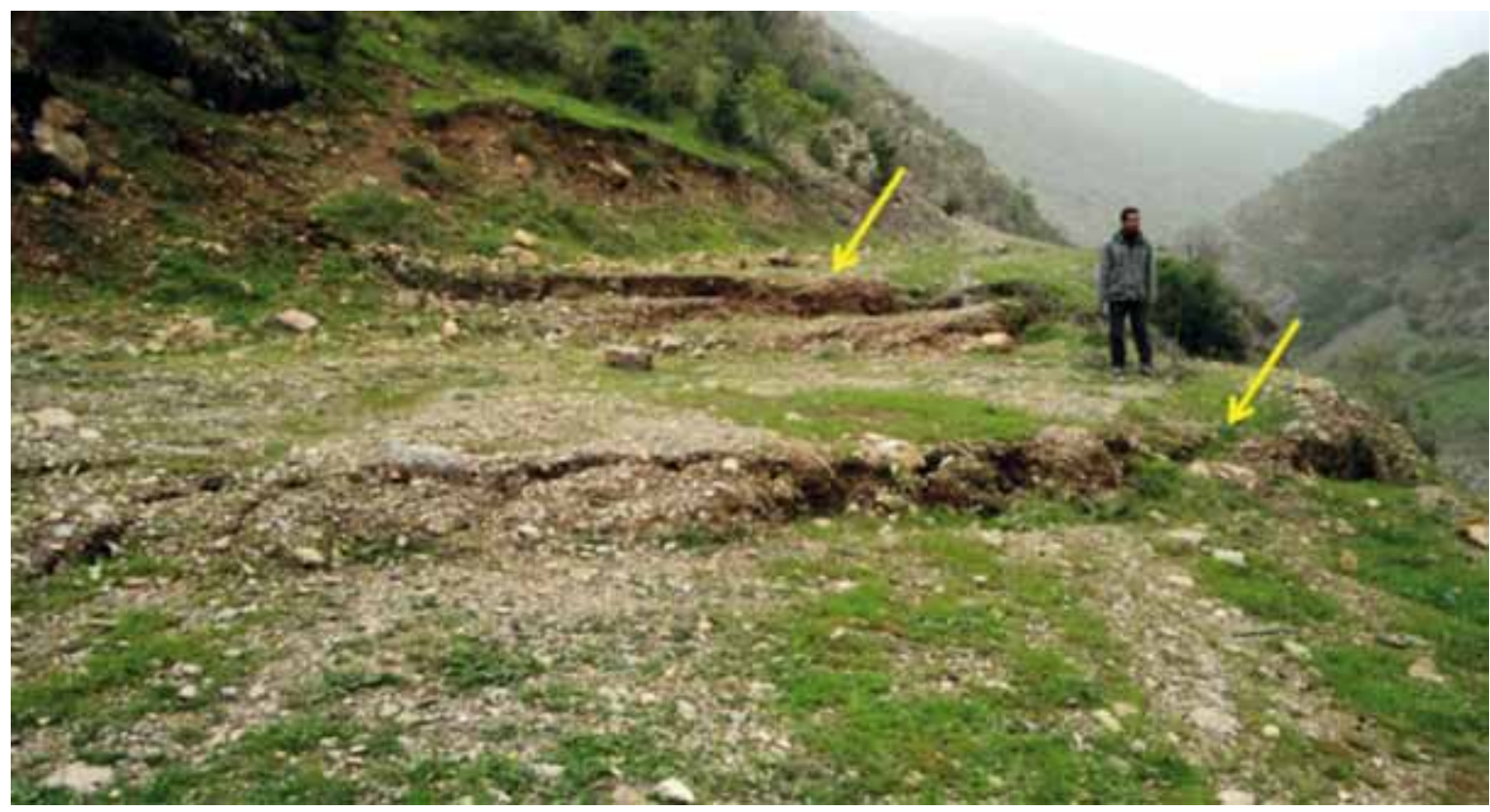

Şekil 18. Gökçekoru Köyü kuzeybatısında, sol sahilde re-aktivite geçirmiş heyelan ve buna bağlı gelişen kırıklar yakın geçmişte yapılan yolu iki yerden etkilemiştir. Lokasyon için Şekil 16'ya bakınız.

Figure 18. A reactivated landslide in the northwest of the Gökçekoru Village, on the left coast and the cracks related with this reactivation which affected the road in two places. For location; see Figure 16. 
Gökçekoru Köyü kuzeybatısında Botan Çayı (Ulu Çay) vadisi yakınında aktif bir heyelan gözlenmiştir (Şekil 18). Bu alanda geri planda görülen heyelanın göreceli yaşı 6 olduğu düşünülmüştür. Fakat bu heyelan alanında reaktivite görülür. En son heyelan günceldir (göreceli yaş: 7) ve buradaki yolda çatlaklar oluşturmuştur (Şekil 18).
Gölgeli Köyü yamaç heyelan döküntüsü ve yamaç döküntüsü üzerinde kurulmuştur. Yamaç yukarıda bulunan heyelanın malzemesi de köy dolayına yamaç döküntüsü olarak akmıştır. Gölgeli Köyü kuzeydoğusunda săg sahilde göreceli yaşı 1 olan heyelan saptanmıştır (Şekil 19 vev 20). Heyelanın oluşmasından sonra yer değiştirmiş heyelan malzemesi üzerinde farklı

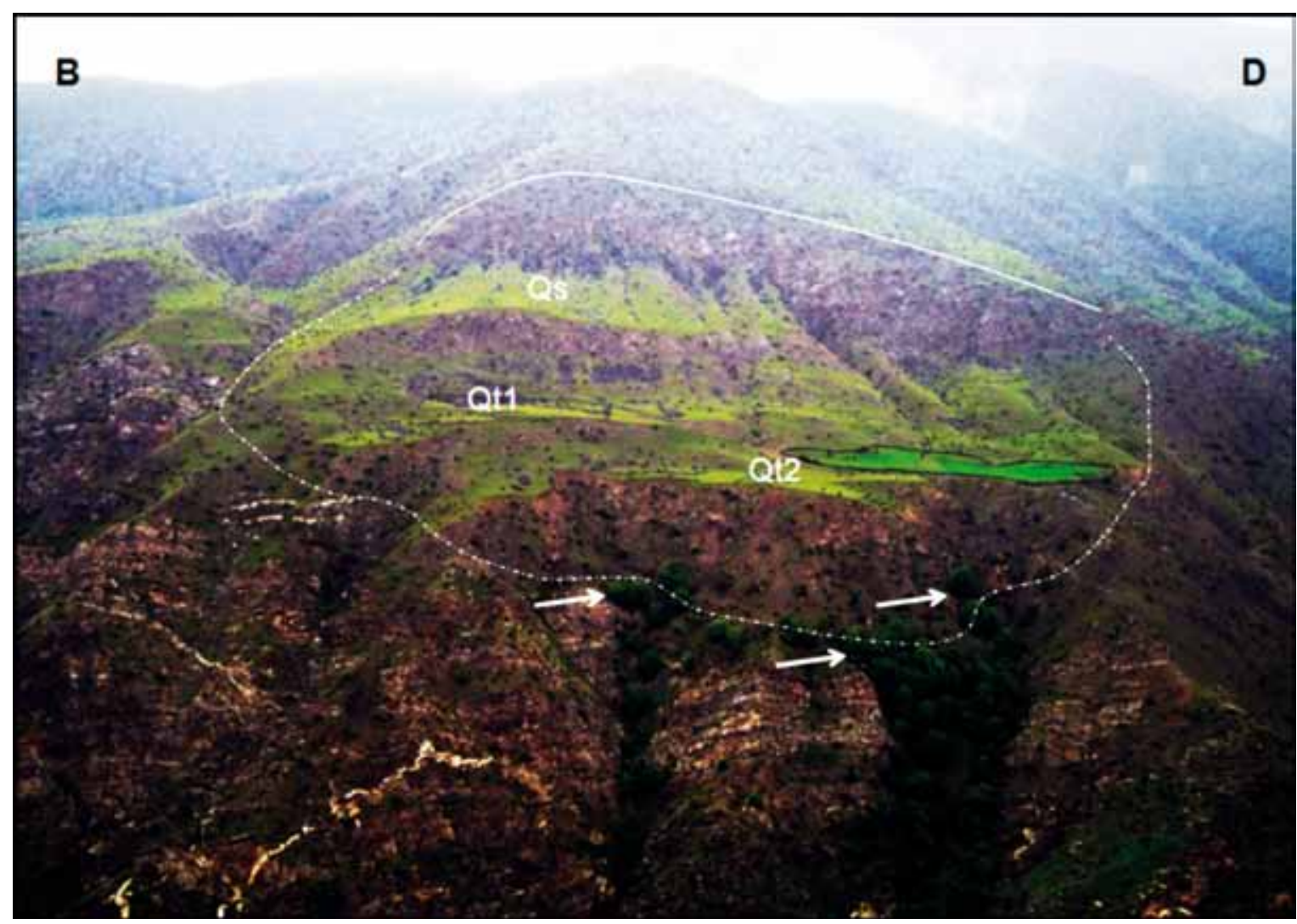

Şekil 19. Gölgeli Köyü kuzeydoğusunda nehrin sağ sahilinde bulunan eski heyelan. İki aşınma yüzeyi (Qt1, Qt2: taraçalar) belirgin olarak görülmektedir. Yer değiştirmiş heyelan malzemesinin tabanına yakın ağaç yoğunlaşması belirgindir. Kayma-sıyrılma yüzeyi boyunca su çıkışı belirgindir. (Qs: yamaç döküntüsü çökelleri). Lokasyon için Şekil 20'ye bakınız.

Figure 19. Ancient landslide located in Northeast of Gölgeli Village on right coast of the river. Two erosonal surfaces (Qt1, Qt2: tarraces) are visible. Trees concentration near base of displace landslide material is evident. Water discharges along the surface of rupture is apparent. (Qs: talus-scree deposit). For location; see Figure 20. 
yaşta iki adet taraça gelişmiştir (Şekil 19). Heyelanın topuk kısmı kısmen aşındırılmıştır. Kayma düzleminin topografyadaki izi vadi tabanından yaklaşık $270 \mathrm{~m}$ yukarıdadır. Bu veri bölgedeki yükselme miktarını ve hızını göstermesi açısından önemlidir. Tektonik yükselme sonucu çok hızlı ve güçlü aşınma olmuştur. Şekil 19'da sağ sahilde görülen taraçalar ile Gökbel, Gölgeli köyleri arasında sol sahilde gözlenen taraçalar hemen hemen aynı kotlardadır. Aynı yaşta olan bu taraçalar Botan Çayı (Ulu Çay) vadisinin geçmiş dönemde bulunduğu aşınma düzlüklerini gösterir. Askıda olan heyelanın kayma düzlemi boyunca su çıkışı görülür. Bu nedenle burada ağaç yoğunluğu fazladır (Şekil 19).
Gölgeli ile Ayvalıbağ köyleri arasında bölgenin en aktif ve güncel heyelanları bulunur (Şekil 20, 21 ve 22). İki köy arasında güneyde 1150-1300 metreler arasinda görülen heyelan taçlarıyla ilgili ilk kayma hareketinin göreceli yaşının 4 olduğu düşünülmüştür. Daha sonra bu alanda heyelan re-aktivitesi olmuş ve göreceli yaşı 6 olan heyelanlar gelişmiştir (Şekil 20). Heyelan alanının topuk kısmında ise güncel (göreceli yaş: 7) heyelanlar saptanmıştır (Şekil 21, 22 ve 23).

Ayvalıbağ ile Gölgeli köyleri arasındaki heyelanlar güneyden kuzeye gençleşir ve iç içedirler (Şekil 21). Botan Çayı (Ulu Çay) yatağına yakın alandaki güncel heyelanın topuğu nehir yatağını ötelemiştir (Şekil 21).

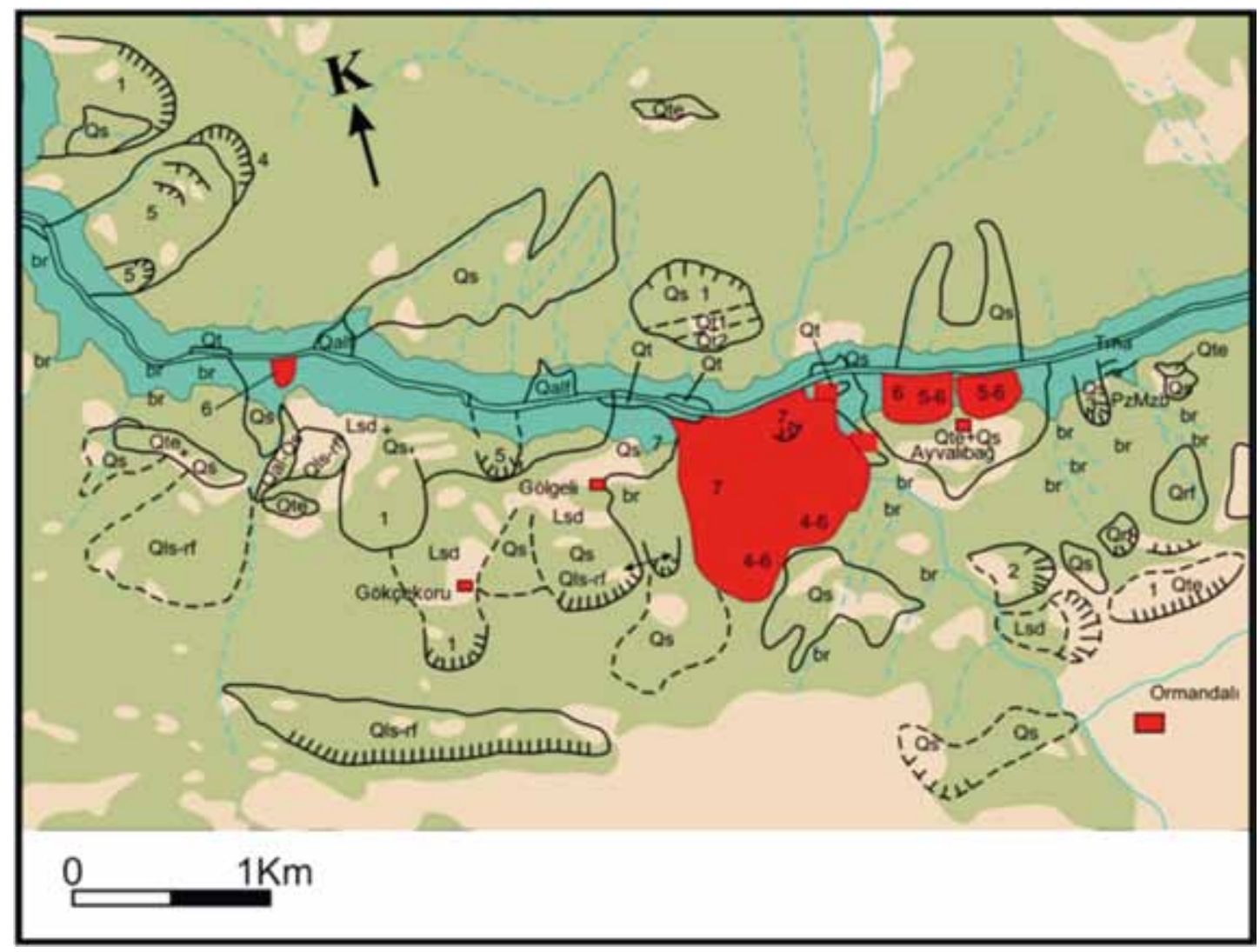

Şekil 20. Gökçekoru-Gölgeli-Ayvalıbağ-Ormandalı dolayının heyelan haritası.

Figure 20. Landslide map of the Gökçekoru-Gölgeli-Ayvalıbağ-Ormandalı area. 
$\mathrm{Bu}$ alandaki en büyük aktif heyelan Şekil 22'de görülmektedir. Heyelanın kayma düzleminin (surface of separation) topografyadaki izi askıdadır. Heyelanın koparak hareket eden zonu (zone of depletion) ve topuktaki yı ğışma zonu (zone of accumulation) belirgindir (Şekil 22). $\mathrm{Bu}$ alandaki güncel ve ikincil heyelanlar nedeniyle mevcut yolların tahrip olduğu görülür.

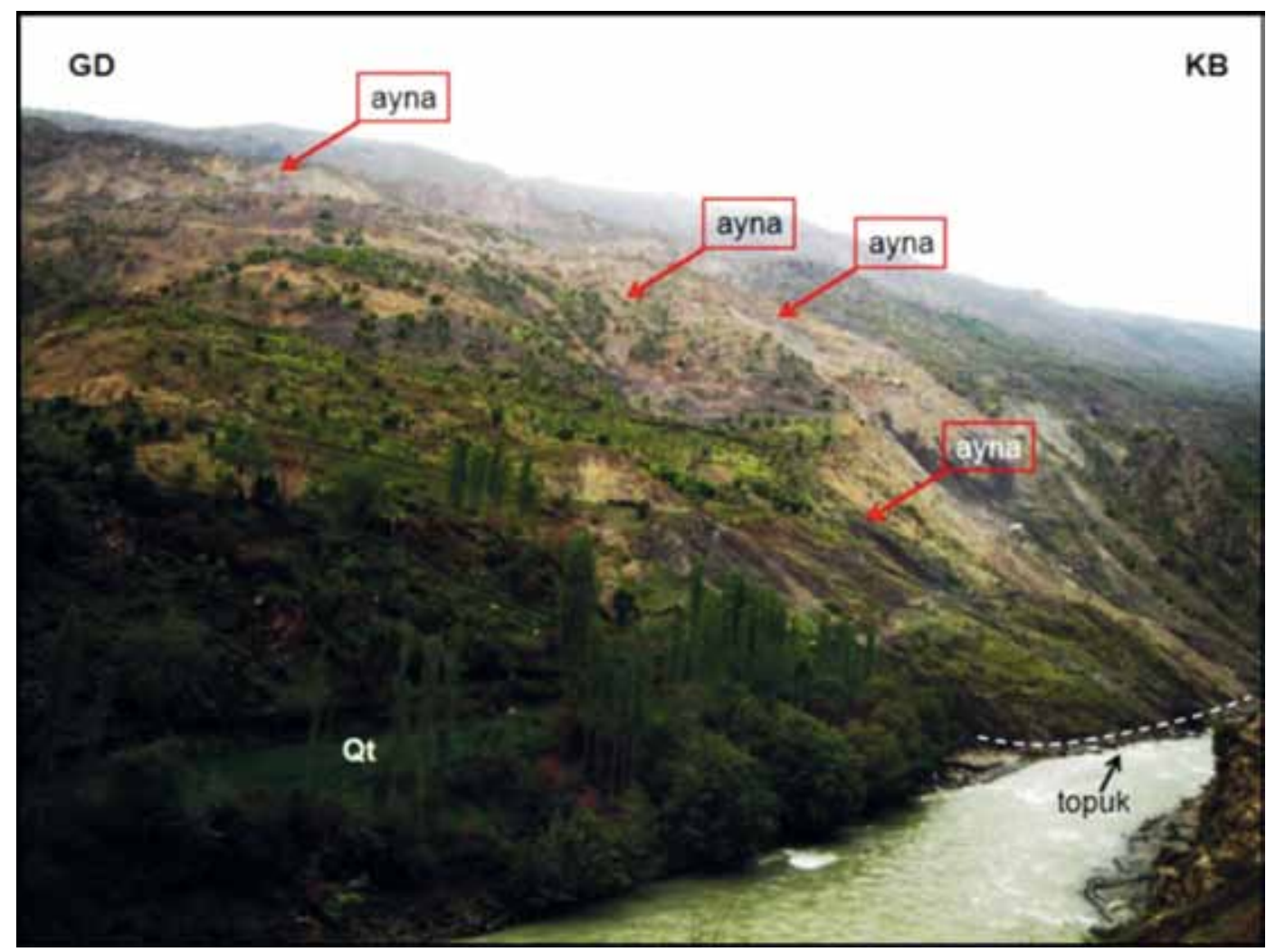

Şekil 21. Gölgeli ve Ayvalıbağ köyleri arasında aktif heyelanların bulunduğu alana (sol sahil) kuzeydoğudan güneybatıya genel bakış. Fotoğrafta farklı yaşta ve birçok heyelan aynası görülmektedir. (Qt: taraça). Lokasyon için Şekil 20’ye bakınız.

Figure 21. General view of active landslide area from northeast to southwest. Area located between Gölgeli and Ayvalıbağ villages (left coast). Several scarp of landslide are seen which are in different age. (Qt: terrace). For location; see Figures 20. 


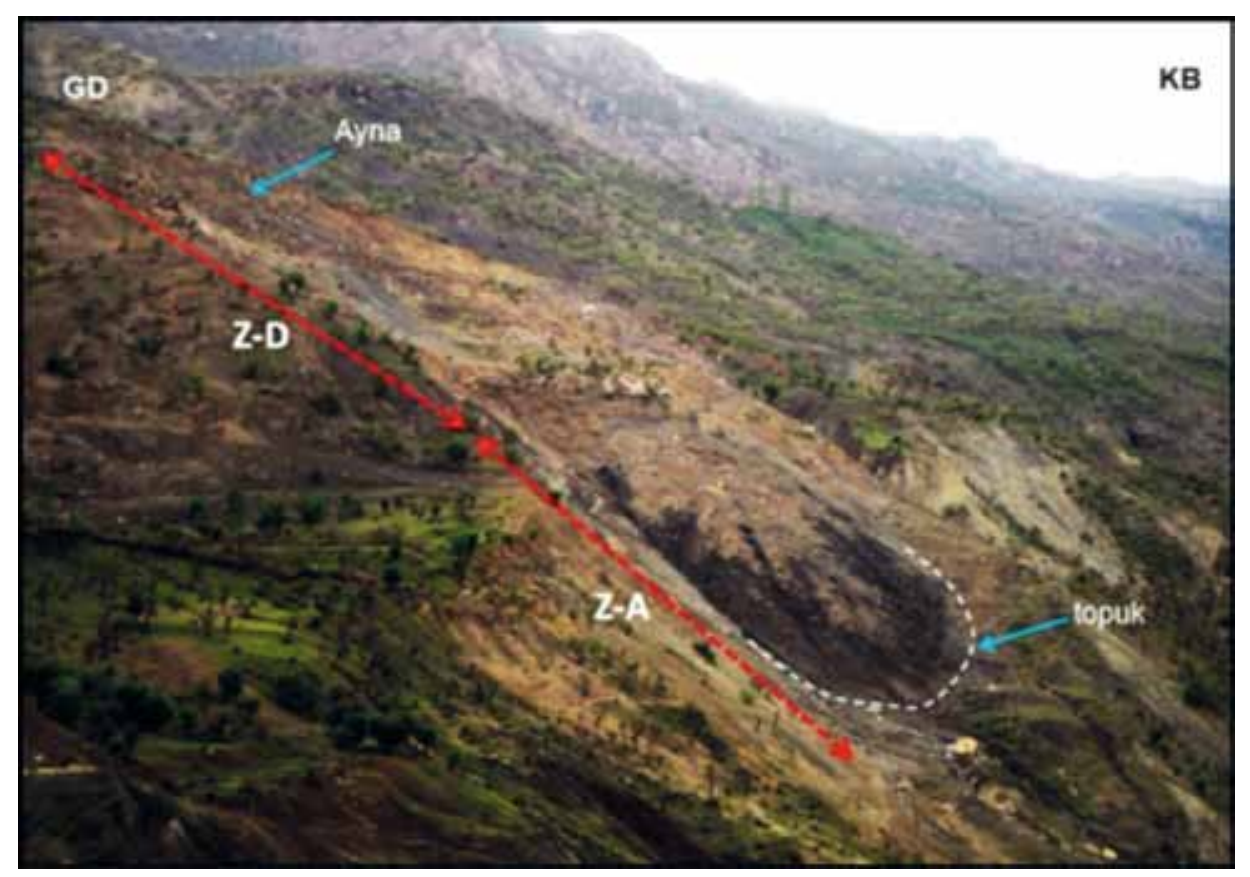

Şekil 22. Gölgeli ve Ayvalıbağ köyleri (sol sahil) arasındaki aktif heyelan alanına bakış. Bölgenin en genç ve büyük heyelanı eski heyelan döküntüsü - malzemesi-talus çökelleri üzerinde oluşmuştur. (Z-D: kayma zonu, Z-A: birikme zonu). Lokasyon için Şekil 20'ye bakınız.

Figure 22. View of active landslide area. Area located between Gölgeli and Ayvalıbăg villages (left coast). The youngest big size landslide of region occurred on ancient landslide debris and scree deposit. (Z-D: zone of depletion, Z-A: zone of accumulation). For location; see Figures 20.

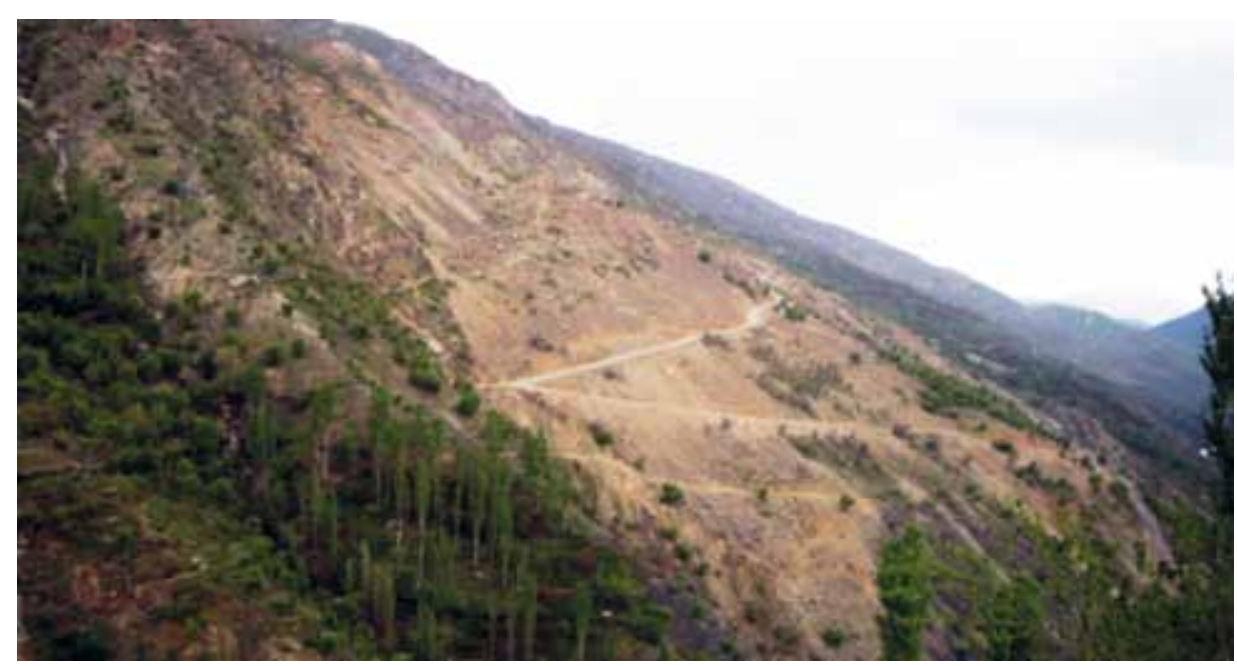

Şekil 23. Yukarıayvalıbağ Mahallesi batısında aktif heyelan alanı. Bu alanda yamaç eğimi çok yüksektir heyelan ve kaya düşmesi dışında yamaç döküntüsü oldukça yaygındır. Lokasyon için Şekil 20’ye bakınız.

Figure 23. Active landslide area to the west of Yukarlayvalıbağ Settlement. Slope inclination is very high in this area and talus-scree deposits are widespread in addition to landslides including rockfall. For location; see Figures 20. 


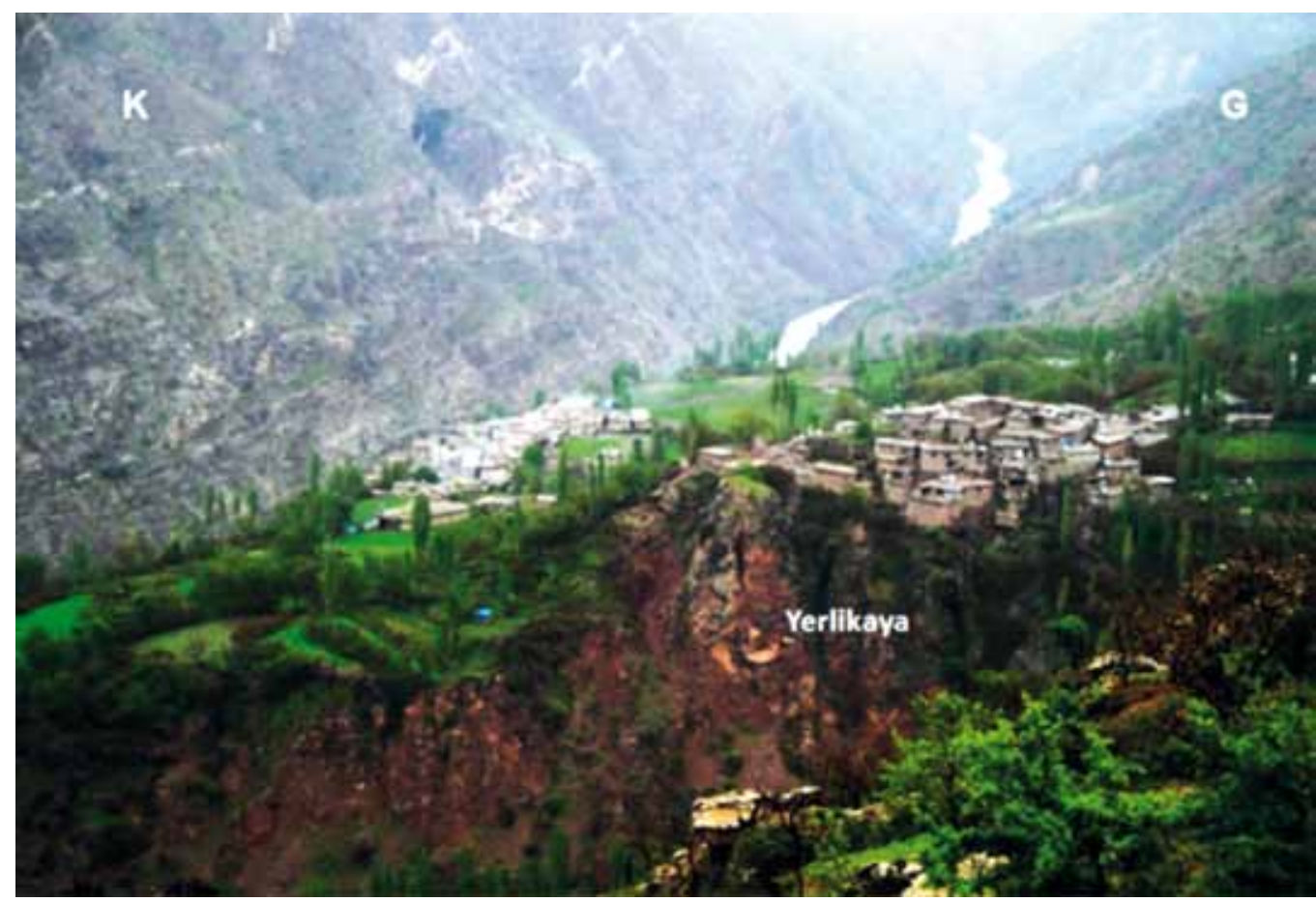

Şekil 24. Ayvalıbağ Köyü ve Yukarıayvalıbağ Mahallesi’ne batıdan bakış (sol sahil). Köyün doğu kesimi eski yamaç döküntüsü (talus) üzerinde kurulmuştur. Köyün batısında ise evlerin bir kısmı yerli kaya üzerindedir. Lokasyon için Şekil 20'ye bakınız.

Figure 24. View to Ayvalıbağ Village and Yukarlayvalıbăg Settlement from the west (left coast). The eastern section of the village is established on talus - scree deposits. Some houses located on the west are situated on bedrock. For location; see Figure 20.

Ayvalıbă̆ Köyü kuzeyinde yamaç döküntüsü çökelleri yaygındır ve bunların vadi tabanına kadar ulaştı̆ğ görülür. Ayvalıbağ Köyü ve Yukarıayvalıbağ Mahallesi (sol sahil) genellikle yamaç döküntüsü üzerinde kurulmuştur (Şekil 24). Köyün kuzeyindeki heyelanların nedenlerinden biri yamaç eğiminin yüksek olmasıdır (Şekil 23). İkinci neden ise Maden Karmaşığ 1 içindeki çamurtaşı katkılarıdır. Suya doygun hale gelen çamurtaşı heyelan için uygun kayma ortamı oluşturur. Ayvalıbă̆ Köyü doğusunda Bitlis Metamorfitleri üzerinde çökel ilişkili olarak Maden Karmaşığı bulunur. Karmaşık üzerine Bitlis Metamorfitleri bindirme ile gelir. $\mathrm{Bu}$ alanda mostrada olan Maden Karmaşığı batı yönünde devam eder ve köyün kuzeyinde heyelan döküntüsü altında kaybolur.

Ayvalıbağ Köyü'nün kuzeyindeki heyelanların göreceli yaşları 5 ve 6 olarak önerilmektedir (Şekil 25, 26, 27 ve 28). Bu alanda aktif heyelanların bulunması dikkate alınması gereken bir konudur. Baraj yapımı sonrası oluşacak göl nedeniyle heyelan malzemesi suya doygun hale gelecek ve yeni heyelanların oluşmasına neden olacaktır. Bu alan köyün batısındaki yerleşim olmayan aktif heyelan alanından farklı durumdadır. Burada bulunan köy bahçeleri baraj gölü sonrası oluşacak heyelanlardan etkilenecektir. Köyün kuzeyindeki alan özellikle bahar aylarında ortamdaki suyun 
artması nedeniyle heyelanların aktivite kazandığ bir alandır. İlkbaharda eski heyelan malzemesinin tabanındaki kayma düzlemi boyunca hareket eden sular vadi tabanına yaklaşınca yüzeye çıkmaktadır. $\mathrm{Bu}$ işlem uzun yıllardır oluştuğu için suyun çıktığı noktalarda traverten birikmiştir. Su çıkışı yeni heyelanları tetiklemektedir. $\mathrm{Bu}$ nedenle burada çamur akmaları yaygındır.

\section{Botan Çayı (Ulu Çay) yatağını} derinleştirirken sağ ve sol sahilde de aşınmaya neden olmaktadır. Özellikle ilkbahar aylarında yükselen sular nehir kenarındaki malzemeyi aşındırmakta, bunların altını oymaktadır. $\mathrm{Bu}$ oyma işlemi özellikle yamaç döküntüsü (molozu) ve heyelan döküntüsü gibi gevşek malzemenin olduğu alanlarda etkin olmaktadır. Barajın bitmesini takip eden evrede su birikip göl oluşunca Botan Çay'ının aşınma etkisi ortadan kalkacaktır. Bu üsteki paragrafta açıklanan su doygunluğu ile ilgili yorum ile çelişiyor gibi gözükse de dikkate alınması gereken bir varsayımdır. Aşınma - oyma işlemi ortadan kalkınca aşınma-oymanın neden olduğu heyelanların sayısı kısmen azalacaktır.

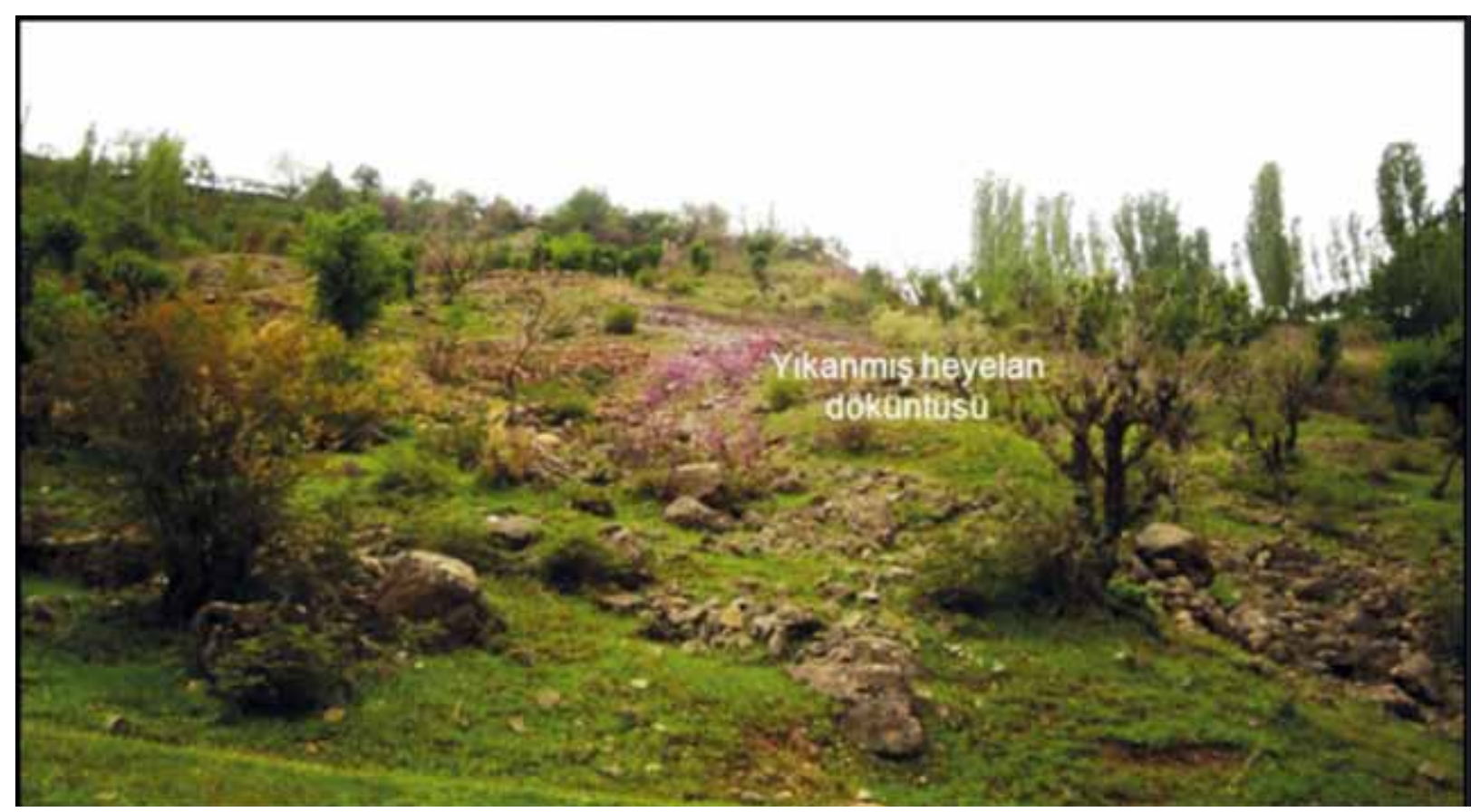

Şekil 25. Ayvalıbağ Köyü kuzeyine, Botan Çayı Nehrinin sol sahilne bakış. Eski heyelan döküntüsü ve hızlı sellenme ile yıkanmış heyelan döküntüsü. Sellenme sonucu heyelan malzemesinin ince taneli kesimi taşınmış, geride kaba taneli unsurlardan oluşan malzeme kalmıştır. Aynı alanda yakın zamanda oluşan heyelanlar da gözlenmiştir. Lokasyon için Şekil 20'ye bakınız.

Figure 25. North of Ayvalıbağ village. Left side of the Botan Çayl (Ulu Çay) River. Flash floods debris (washout debris); floodwaters washed landslide debris and fine landslide material removed from displaced landslide material. Recent landslide activity observed in surrounding area. For location; see Figure 20. 


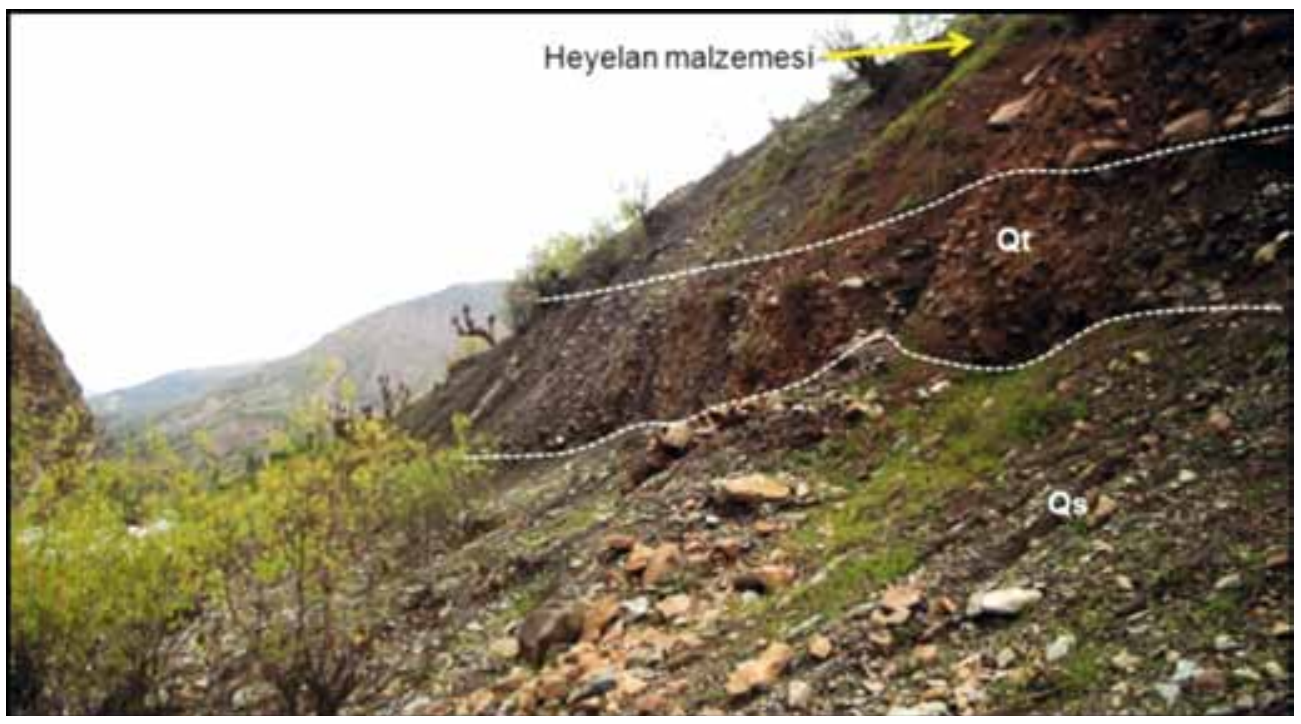

Şekil 26. Ayvalıbağ Köyü kuzeyi Botan Çayı (Ulu Çay) Vadisi’nin sol sahilinde eski bir heyelan malzemesi, yamaç döküntüsü (Qs) ve taraça çökelleri (Qt). Fotoğrafta görülen alan günümüzde duraylıdır. Lokasyon için Şekil 20’ye bakınız.

Figure 26. Old landslide debris, talus-scree ( $Q s)$ and terrace deposits $(Q t)$ are seen in the north of the Ayvalibağ village, on the left coast of the Botan Çayı (Ulu Çay) River. The area seen on the photo is presently stable. For location; see Figure 20.

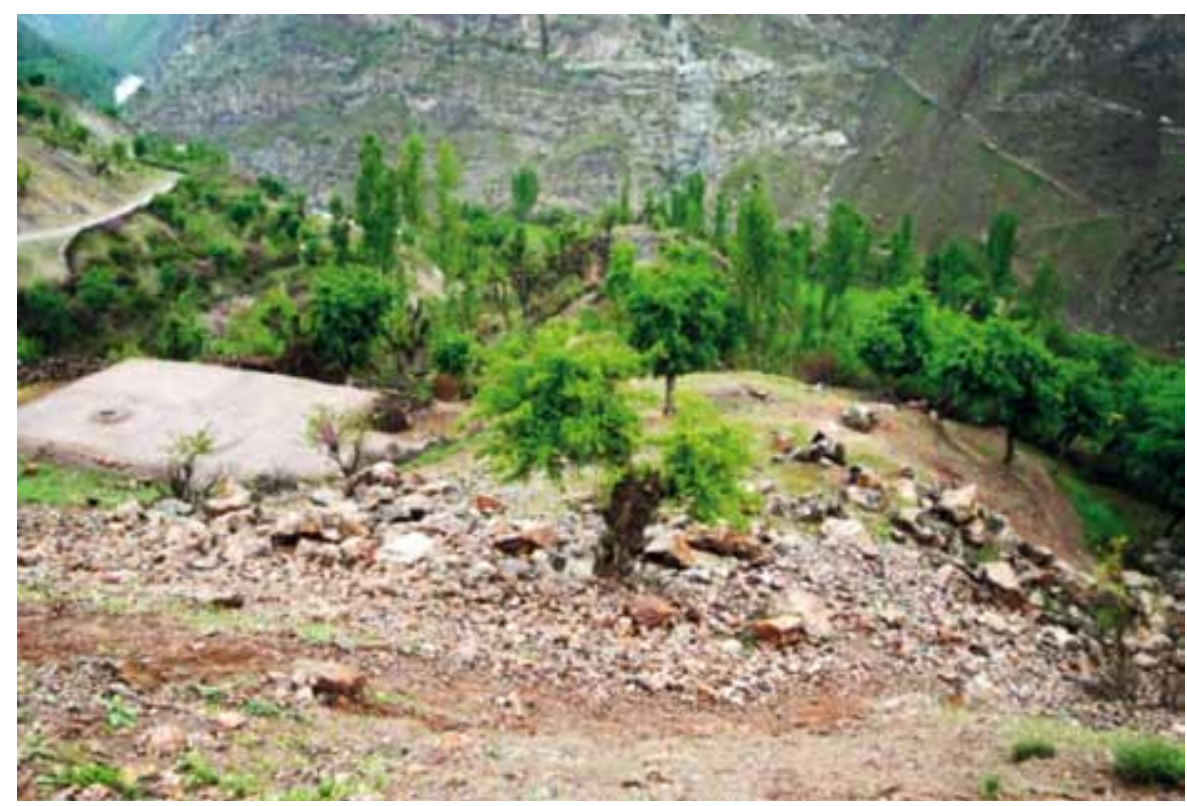

Şekil 27. Botan Çayı (Ulu Çay) sol sahilindeki Ayvalıbağ Köyü kuzeybatısına, bakış. Yakın zamanda oluşan kaya düşmesi türündeki heyelan aktivitesi. Lokasyon için Şekil 20'ye bakınız.

Figure 27. Northwest of Ayvalıbağ village, left side of the Botan Çayı (Ulu Çay) River. Recent landslide-rockfall activity. For location; see Figure 20. 


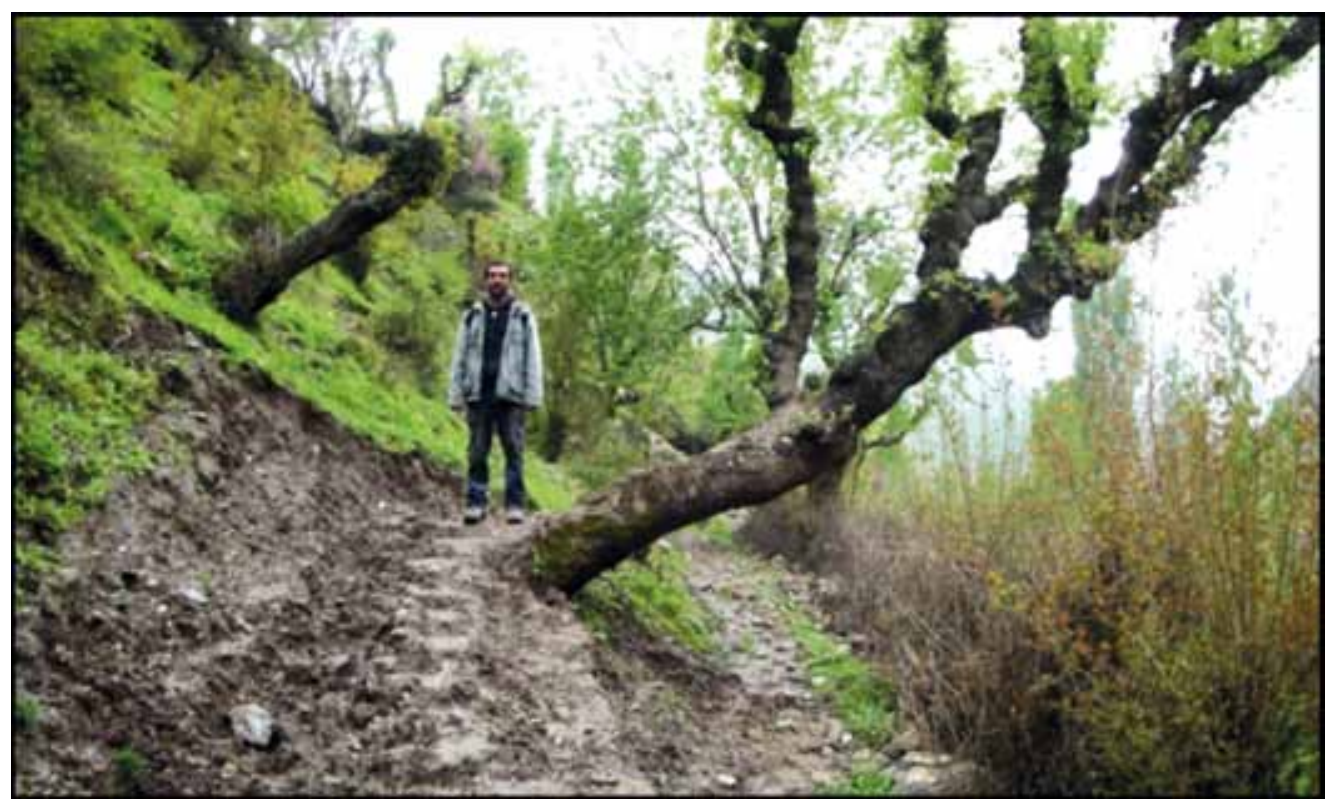

Şekil 28. Botan Çayı (Ulu Çay) sol sahilindeki Ayvalıbağ Köyü kuzeybatısına, bakış. Eğilmiş ağaç eski bir heyelan aktivitesini işaret etmektedir, düşey dallar eski heyelan sonrası büyümüştür. Bu alanda yakın zamanda olmuş bir heyelan aktivitesi gözlenmemiştir. Lokasyon için Şekil 20'ye bakınız.

Figure 28. Northwest of Ayvalıbağ village, left side of the Botan Çayl (Ulu Çay) River. Bended trees indicating ancient landslide activity, vertical branches growth after the landslide. No indication for recent landslide activity at this side. For location; see Figure 21.

Ormandalı ile Ayvalıbağ köyleri arasında yan derenin batısında iki adet göreceli yaşları 1 ve 2 olan iki eski heyelan haritalanmıştır. Bunlar bölgedeki diğer heyelanlardan farklı olarak doğudan batıya kaymışlardır. Heyelan malzemesi önemli oranda aşındırılıp vadi aşağıya taşınmıştır.

Ayvalıbağ ile Narsuyu köyleri arasında sınırlı alanlarda yamaç döküntüsü, heyelan döküntüsü ve taraça görülür. Narsuyu Köyü dolayında heyelan oluşumu sonrası yamaç aşağıya akan malzemenin nehir yatağını karşı kıyı yönünde ötelemiştir (Şekil 29).

Narsuyu güneydoğusunda 1350 m X $1150 \mathrm{~m}$ boyutlarında inceleme alanının en büyük heyelanı haritalanmıştır (Şekil 29). Bu heyelanın göreceli yaşının 1 olduğu düşünülmektedir. Narsuyu Köyü bahçeleri heyelanın topuk kısmında yer alır. Heyelanın tabanını oluşturan kayma düzlemi boyunca toplanan sular topuk bölgesindeki bahçeler dolayında yüzeye çıkar. Bahçelerin sulanması bu su sayesinde olmaktadır. Narsuyu kuzeydoğusundaki bahçelerin olduğu alanda gözlenen heyelanın göreceli yaşı 5 ve 6 olarak tanımlanmıştır (Şekil 29). Bu alanda baraj yapımı sonrası oluşacak göl nedeniyle gevşek zeminde su doygunluğu artacak yeni kaymalar olacaktır. Buna karşın gölün oluşmasıyla birlikte Botan Çayı'nın aşınma - oyma etkisinin azalması beklenmektedir. Söz konusu heyelan alanı üzerinde çok kalın yamaç döküntüsü birikmiştir (Şekil 29).

Güleçler Köyü’nün bahçelerinin olduğu alan eski yamaç döküntüsü (Qs1) üzerindedir. Köyün güney batısında ise daha genç olan yamaç döküntüsü (Qs2) birikmiştir (Şekil 29). Köyün bir bölümü yerli kaya üzerinde, kalan kesimi ise yamaç döküntüsü üzerinde kurulmuştur. Güleçler Köyü bahçelerinin olduğu alanda yamaç eğimi 
yüksektir. Yamaç döküntüsü içine sızan sular yerli kaya düzlemine ulaştıktan sonra yüzeyler ve bu su bahçeler için kullanılır. Güleçler Köyü kuzeybatısında yamaç döküntüsü içinde oluşmuş eski bir heyelan (göreceli yaş: 3) bulunmaktadır. $\mathrm{Bu}$ alandaki bitki örtüsü ve morfoloji, heyelanın eski olduğunu gösterir.

Yamaç döküntüsü malzemesinde toplanan suların yüzeylendiği alanlarda güncel çamur akmaları saptanmıştır (Şekil 30). Çamur akması 2010 yılı Mart ayı başında gerçekleşmiştir. $\mathrm{Bu}$ çamur akması 1/25000 ölçekli haritaya çizilemeyecek derecede küçüktür. Çamur akmalarının yüzeysel suyun yoğun olduğu ilkbahar aylarında görüldüğü köylüler tarafindan belirtilmiştir.

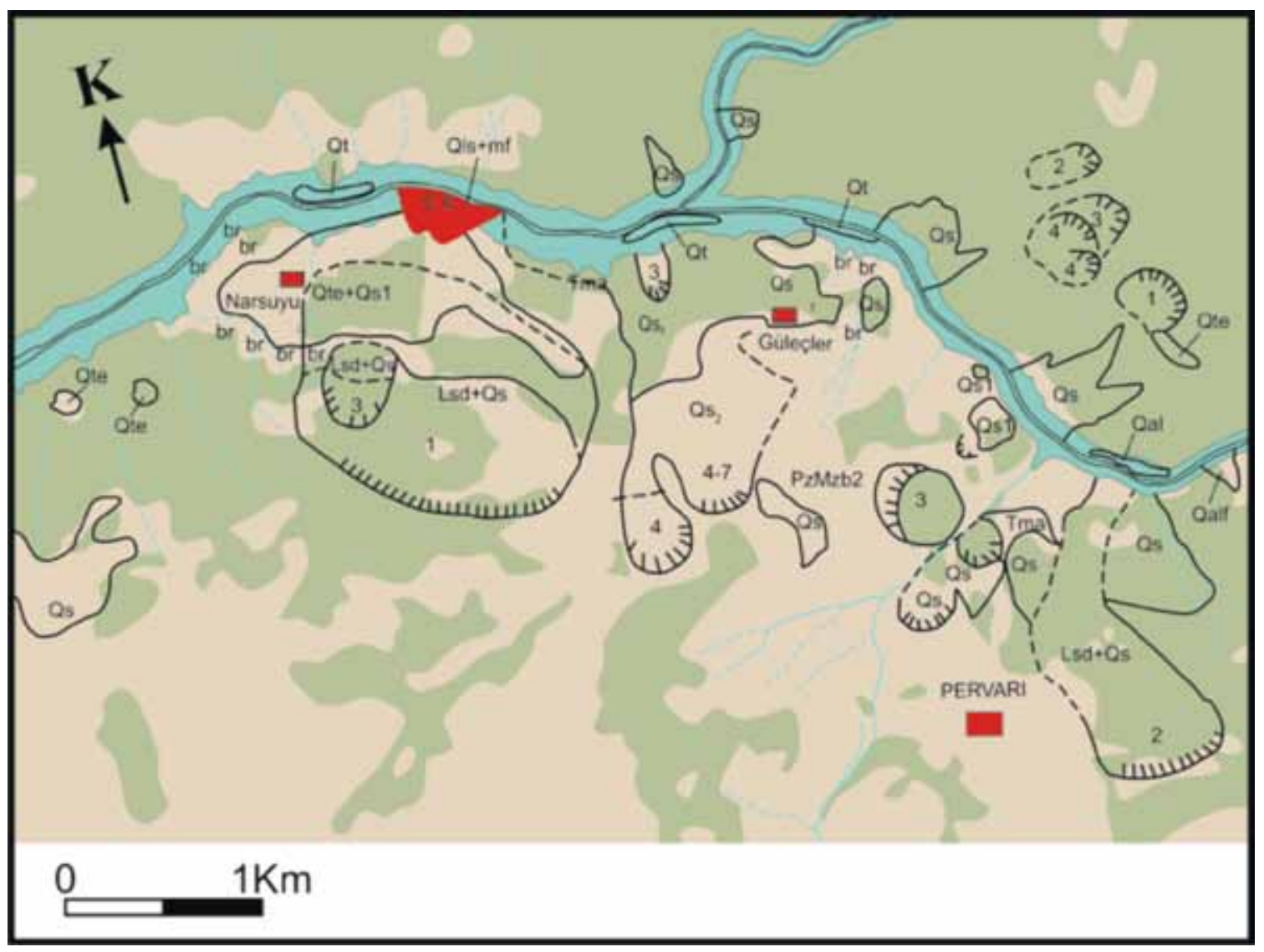

Şekil 29. Narsuyu-Güleçler-Pervari alanının heyelan haritası.

Figure 29. Landslide map of the Narsuyu-Güleçler-Pervari area. 


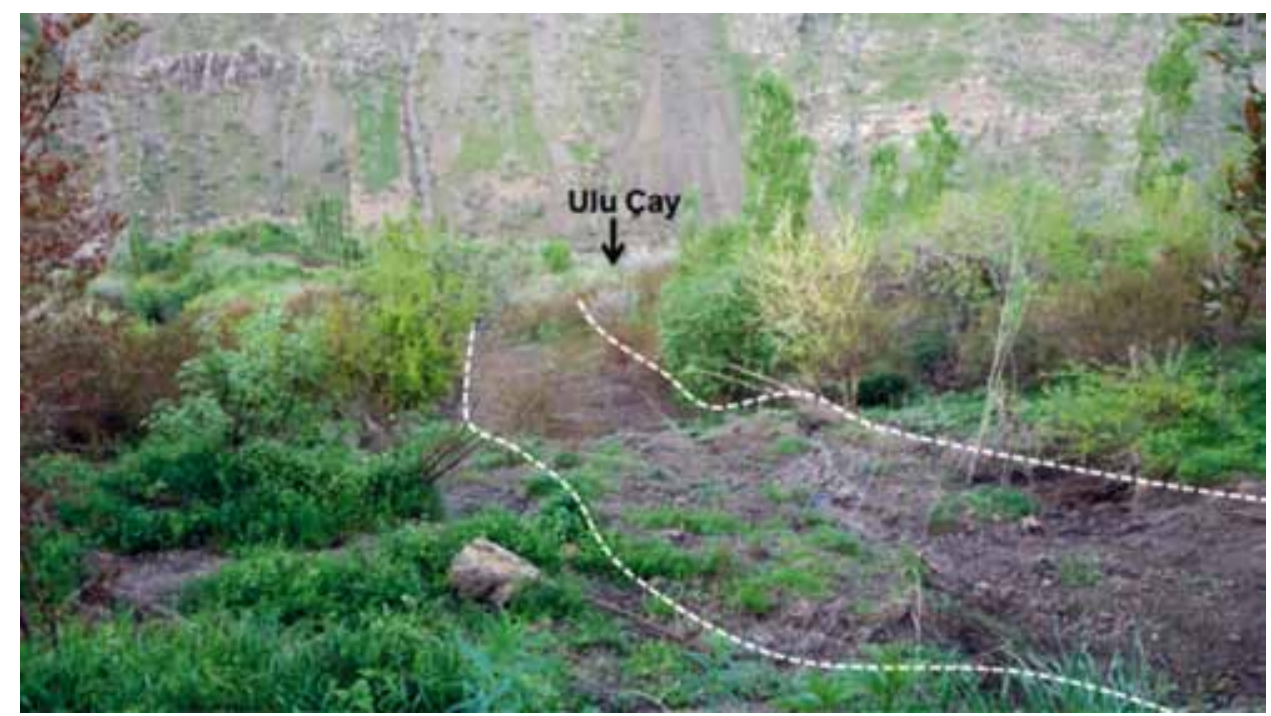

Şekil 30. Güleçler Köyü kuzeyindeki bahçelerde 2010 yılı Mart ayında oluşan toprak akması. Toprak ve ağaçlar birlikte vadi yönünde akmıştır. Lokasyon için Şekil 29'a bakınız.

Figure 30. The mudflow (earthflow) occurred in March 2010 in the gardens located to the north of the Güleçler village. The earth and the trees have glided down towards the valley. For location; see Figure 29.

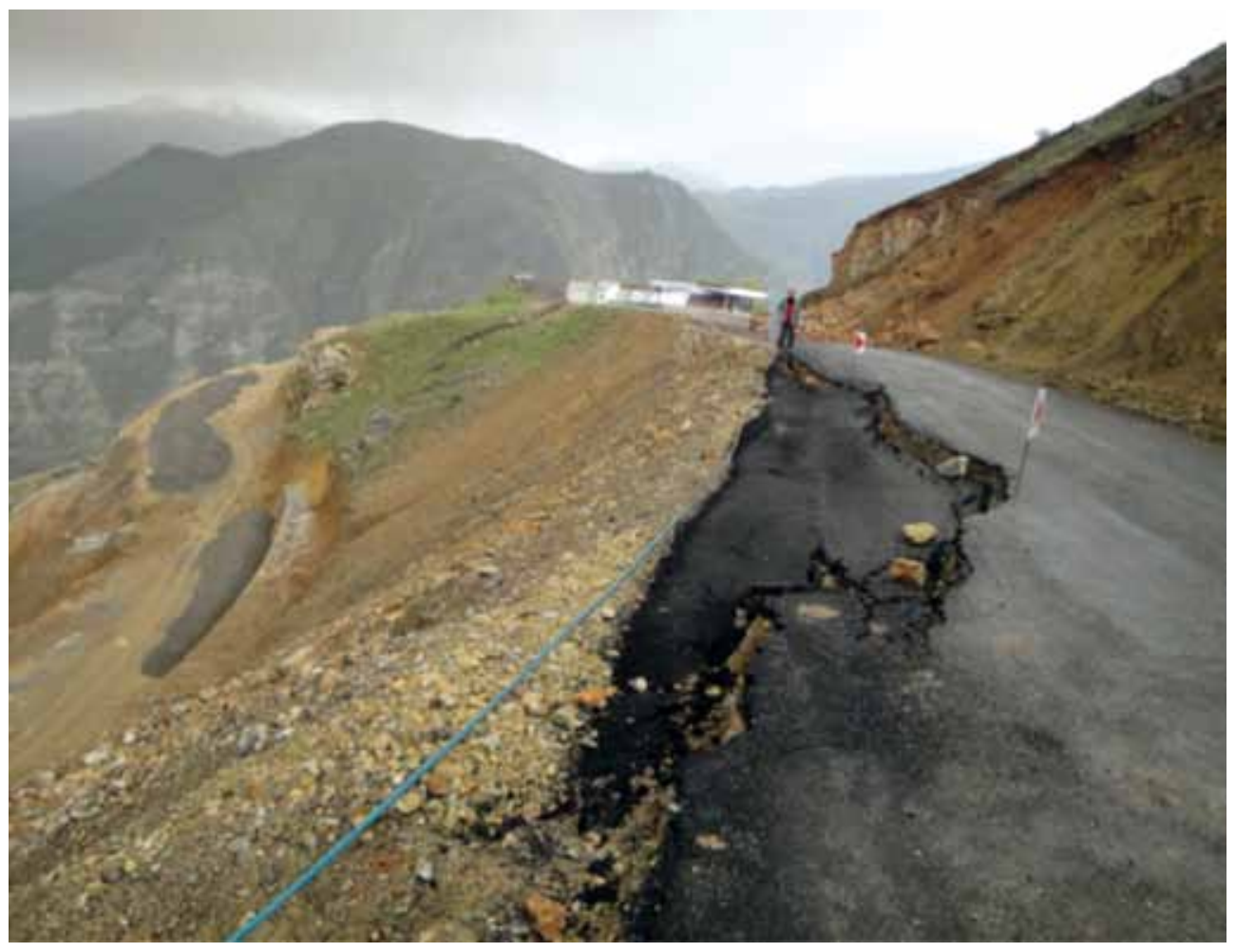

Şekil 31. Pervari kuzeybatısında mevcut yolda 2010 yılı Nisan ayında oluşan heyelan ve çatlakları. Yeni gelişen heyelan Siirt-Pervari ana yoluna zarar vermiştir.

Figure 31. The landslide and its cracks occurred on the newly constructed road in the northwest of Pervari in April 2010. Landslide also damage to the Siirt-Pervari main road. 
Güleçler Köyü güneybatısında Pervari yolu yakınında haritalan iki heyelan vardır. Söz konusu heyelanların taç kısmı karayolunun güneyinde kalır. Heyelandaki ilk hareketin göreceli yaşının 4 olduğu düşünülmektedir. $\mathrm{Bu}$ heyelanlardan bir tanesi 2010 Nisan ayında bu çalışma devam ederken tekrar aktif olmuş yeni kayma ile Pervari yolunda ve bu alanda yeni yapılmakta olan yol üzerinde hasar yaratmıştır (Şekil 31). gurup halinde olanı, iç içe vadi yönünde gençleşen üç heyelandan oluşur. Bu üçlü heyelanın göreceli yaşlarının 3 ve 4 olduğuna karar verilmiştir. $\mathrm{Bu}$ alanda en kuzeydeki heyelanın göreceli yaşı ise 2'dir (Şekil 29). Söz konusu heyelanların malzemesi aşındırılmış ve yamaç aşağıya akarak yamaç döküntüsü oluşturmuştur. $\mathrm{Bu}$ alandaki üçüncü heyelanın göreceli yaşı 1 olup, heyelanın malzemesi önemli oranda aşınmıştır (Şekil 29

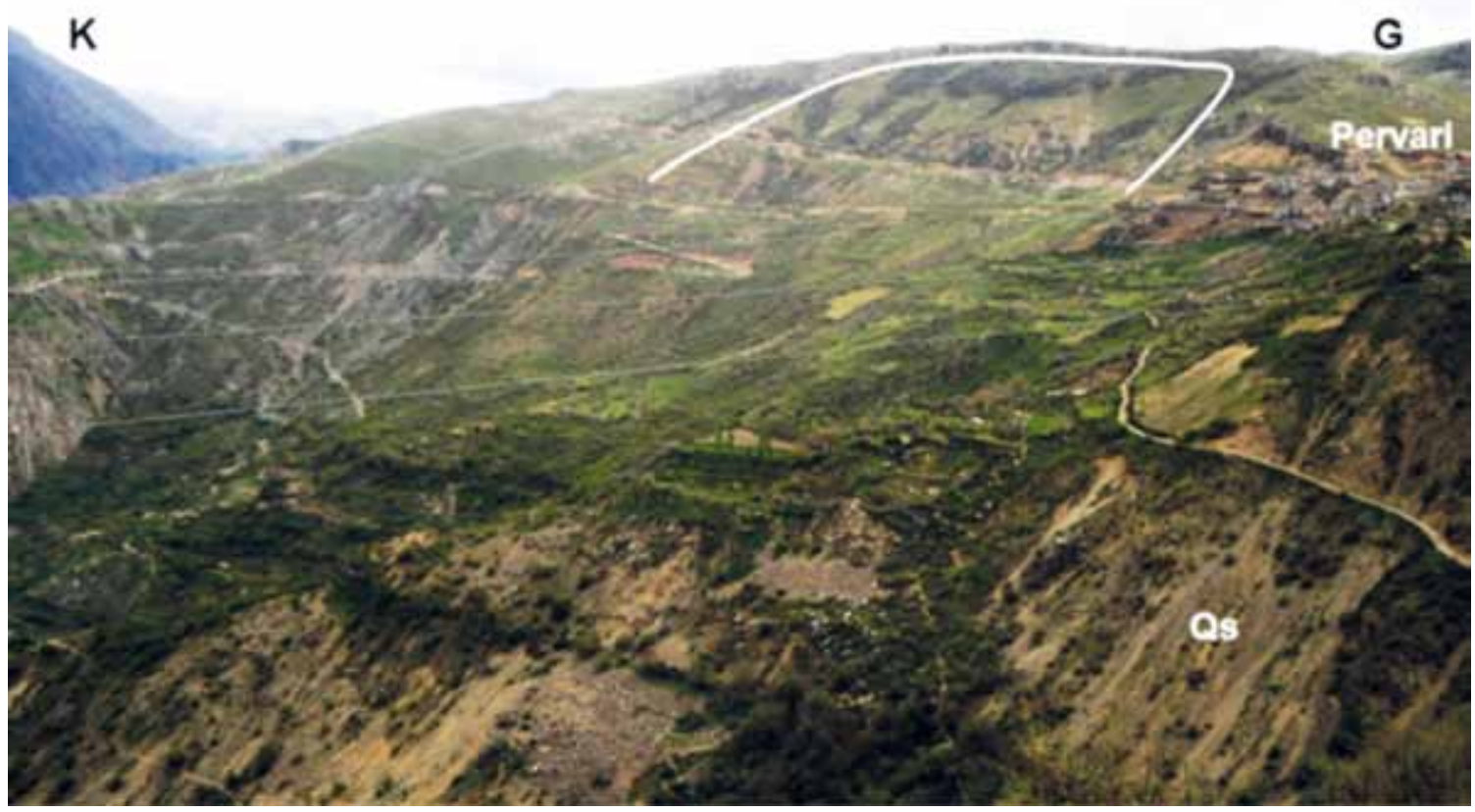

Şekil 32. Pervari doğusuna bakış. Göreceli yaşı 2 olan heyelan ve yamaç döküntüsü (talus; Qs) çökelleri görülmektedir. Lokasyon için Şekil 29'a bakınız.

Figure 32. Wiev of east of Pervari. A landslide with relative age of 2 and talus-scree (Qs) deposit. For location; see Figure 29.

Pervari ilçesi dolayında (sol sahil) farklı yaşlarda ve farklı boyutlarda üç tane heyelan haritalanmıştır (Şekil 7 ve 29). Aynı alanda heyelan döküntüsü, yamaç döküntüsü birikmesi de vardır. Göreceli yaşı 2 olan heyelanın taç kısmı 1550 m yüksekliktedir (Şekil 32).

Pervari kuzeydoğusunda sağ sahilde üç adet heyelan haritalanmıştır (Şekil 29). Bunlardan ve 33). Aşınma miktarı çok fazla olduğu için heyelanın kayma düzlemi neredeyse tümüyle görünür hale gelmiştir. Aşınan heyelan malzemesi yamaç aşağıya akarak yelpaze şeklinde yamaç döküntüsü birikimine neden olmuştur (Şekil 33). Söz konusu heyelanın aşınma düzlemi aynı zamanda eski taraça -aşınma yüzeyi olarak yorumlanmıştır. 


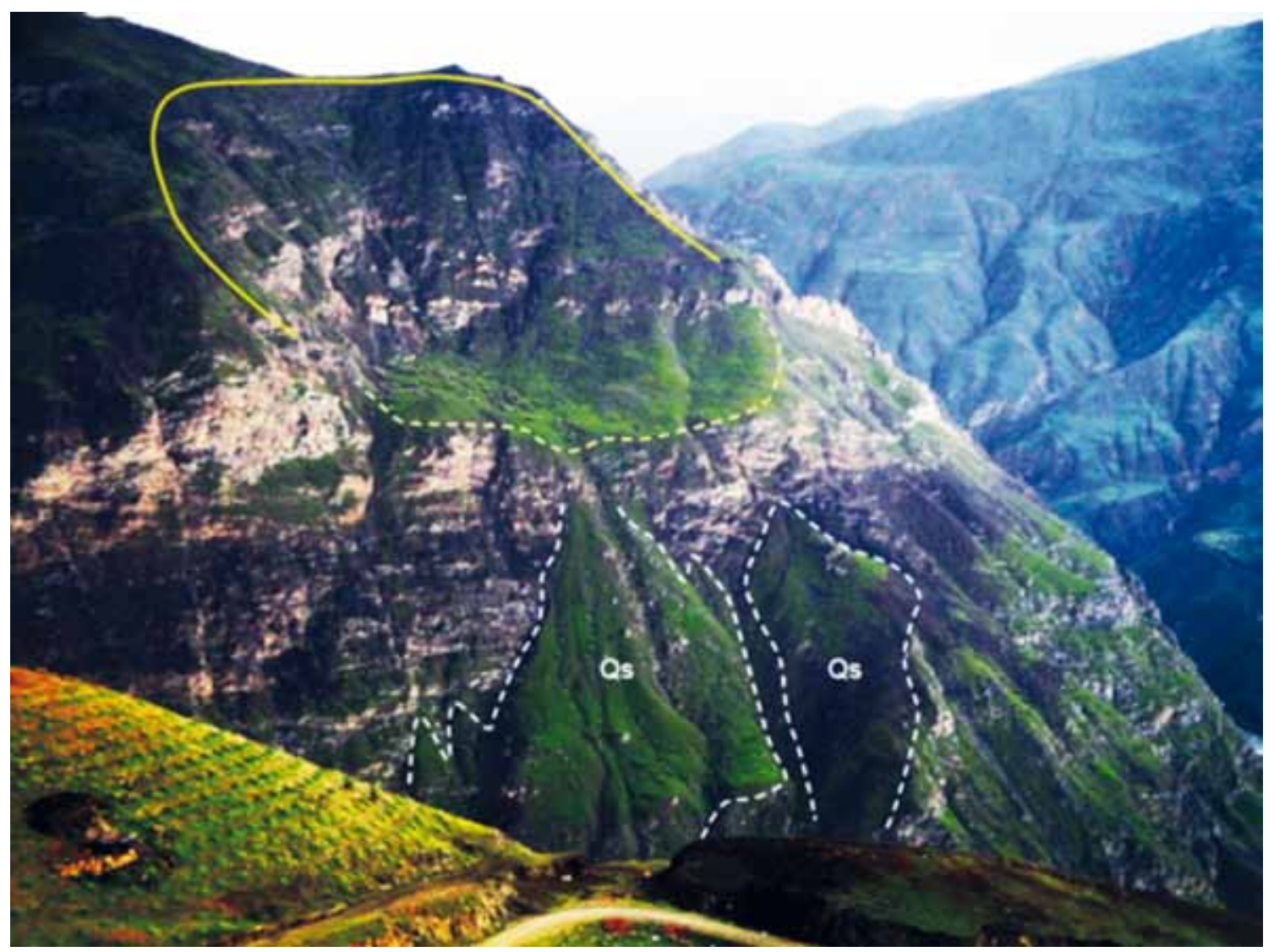

Şekil 33. Pervari kuzeydoğusunda sağ sahilde asılı heyelan ve yamaç döküntüsü çökelleri (Qs). Heyelanların kayma düzlemi aşınma nedeniyle görünür hale gelmiştir. Lokasyon için Şekil 29'a bakınız.

Figure 33. Hanging landslide and scree-talus deposits $(Q s)$ observed in the northeast of Pervari. Surface of rupture and surface of separation of landslide has become visible due to extensive erosion. For location; see Figure 29.

Çetin Baraj aksı, İncecik Köyü, Beyaz Köprü arasında ve dolaylarında Büyük Çay vadisi boyunca gözlenen Kuvaterner çökelleri ve heyelanların genel özellikleri

Bu bölümde Büyük Çay'ın Botan Çayı'na bağlandığı yerden başlayarak vadi boyunca haritalanan heyelan, taraça ve yamaç döküntüsü alanları tanıtılacaktır. Büyük Çay vadisi boyunca baraj göl alanı içinde sorun yaratacak bir heyelan tespit edilmemiştir.
Belençay Köyü güneydoğusunda sağ sahilde 2, sol sahilde 3 adet heyelan haritalanmıştır. Bunlardan dört tanesinin göreceli yaşının 1, bir tanesinin ise 2 olduğuna eldeki veriler doğrultusunda karar verilmiştir. Sol sahilde bulunan iki büyük heyelanın malzemesi önemli oranda aşınmıştır. $\mathrm{Bu}$ heyelanların aşınmış olan topukları askıdadır. Topukların nehir yatağından yüksekliği $500 \mathrm{~m}-600 \mathrm{~m}$ arasındadır. 


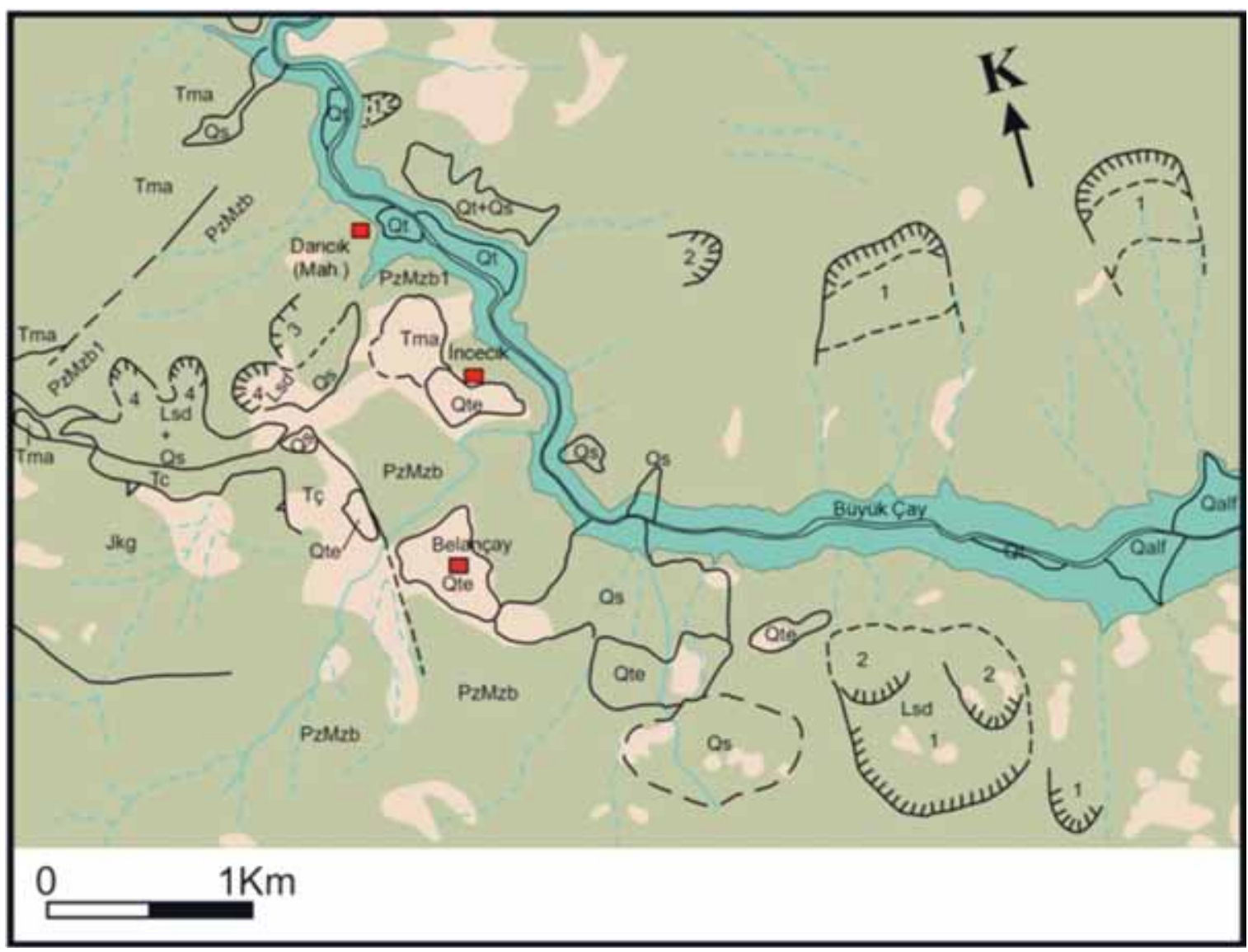

Şekil 34. Darıcık-İncecik-Beleçay ve Büyük Çay dolayının heyelan haritası.

Figure 34. Landslide map of the Darıcı-Incecik-Beleçay and Büyük Çay area.

Belençay Köyü güneydoğusundaki en büyük heyelanın göreceli yaşının 1 olduğu düşünülmektedir. Heyelanın taç kısmı 1300 m dolayındadır. Heyelan alanında aşağı kotlarda daha genç, göreceli yaşı 2 olan iki heyelan daha vardır (Şekil 34, 35 ve 36). Heyelanın çok eski olması ve aşırı aşınma nedeniyle taç kısmı zor tanınır. Heyelan döküntüsünün olduğu alan düşük eğimlidir.
Belençay Köyü güneydoğusunda eski taraçaların varlığını gösteren aşınma düzlükleri belirgindir. Aynı alanda bahçelerin olduğu düşük eğimli yamaçlarda yamaç döküntüsü birikmiştir (Şekil 34).

Belençay doğusunda sağ ve sol sahilde iki adet alüvyon yelpazesi haritalanmıştır. Aynı alanda farklı yaşlarda alüvyon taraçaları gözlenmiştir (Şekil 34). 


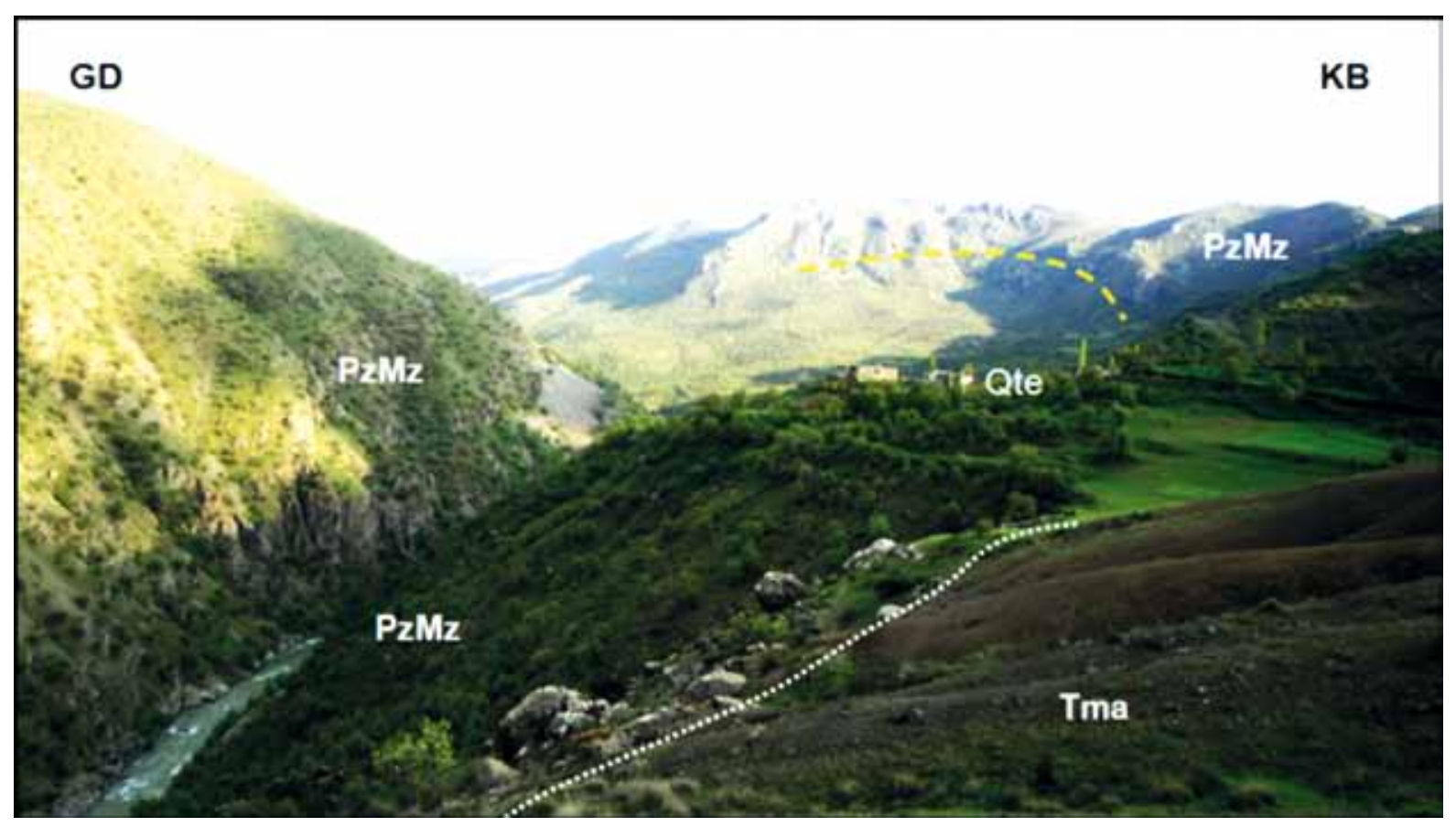

Şekil 35. Büyük Çay vadisi sağ sahilinde İncecik Mahallesi dolayına bakış. Köy eski aşınma düzlüğü - taraça üzerine kurulmuştur. Köy civarında bulunan bazı arkeolojik buluntu köyün kurulduğu alanın en az son 2000 yıldır duraylı olduğu göstermektedir. (Qte: eski aşınma-çökelme yüzeyi - taraça). Geri planda çok eski bir heyelanın taç kısmı görülmektedir. Lokasyon için Şekil 34'e bakınız.

Figure 35. View to Incecik Settlement on the right coast of Büyük Çay valley. The village is located on an old erosional surface - terrace. The archaeological findings collected around the village indicate that the area on which the village was located has been stable at least for the last 2000 years. In the background, crown of a very old landslide is observed. (Qte: ancient erosional surface - terrace). For location; see Figure 34.

İncecik Mahallesi (sağ sahil) eski aşınma düzlüğü üzerine kurulmuştur (Şekil 35). Mahalle civarında gözlenen seramik parçaları arkeologlara gösterilmiştir (sözlü görüşme; Dr Rüstem Arslan, Arkeolog Candan Kozanl1). Arkeologların verdiği bilgi dikkate alındığında İncecik civarındaki bu düzlüğün 2000-3000 yıllık olduğu söylenebilir. İncecik Mahallesi güney ve güneydoğusundaki düzlükler de eski taraça düzlükleridir. Bunların da duraylı olduğu ve en az son 2000 yıldır duraylı kaldığını gösterir morfolojik veriler vardır. Şekil 36'da görülen ve göreceli yaşı 1 kabul edilen heyelan söz konusu taraçaların gerisinde yüksek kotlarda kalır. Heyelanın taraçalar ile olan ilişkisi dikkate alınarak söz konusu heyelan için 1 göreceli yaşı önerilmiştir. 


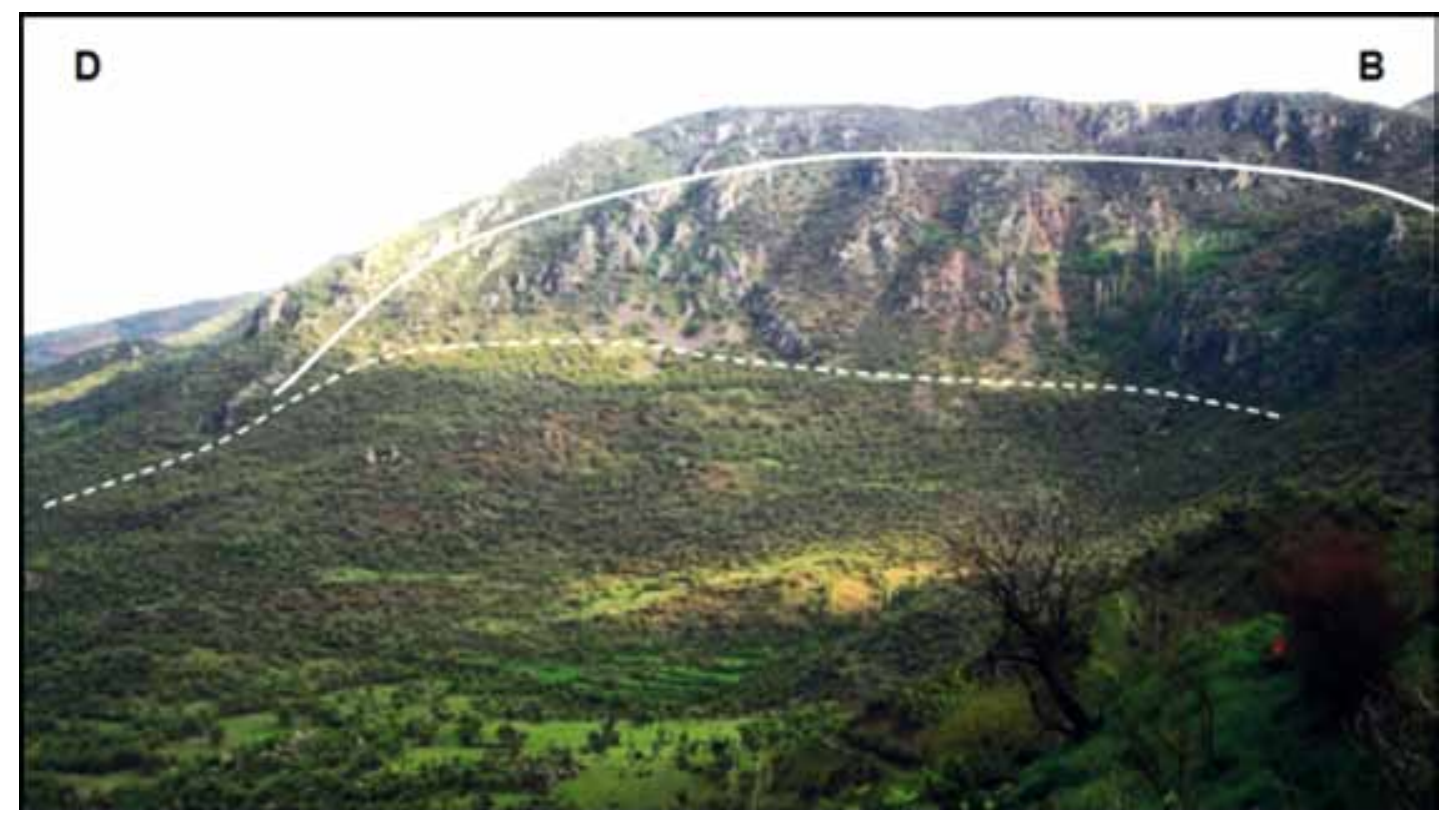

Şekil 36. Büyük Çay vadisi sağ sahilinde Beleçay Köyü güneydoğusundaki bahçelere bakış. Fotoğrafta çok eski bir heyelanın taç kısmı görülmektedir. Lokasyon için Şekil 34'e bakınız.

Figure 36. View to the gardens located in the southeast of Belençay Village on the right coast of Büyük Çay valley. Photo shows the crown of an ancient landslide. For location; see Figure 34.

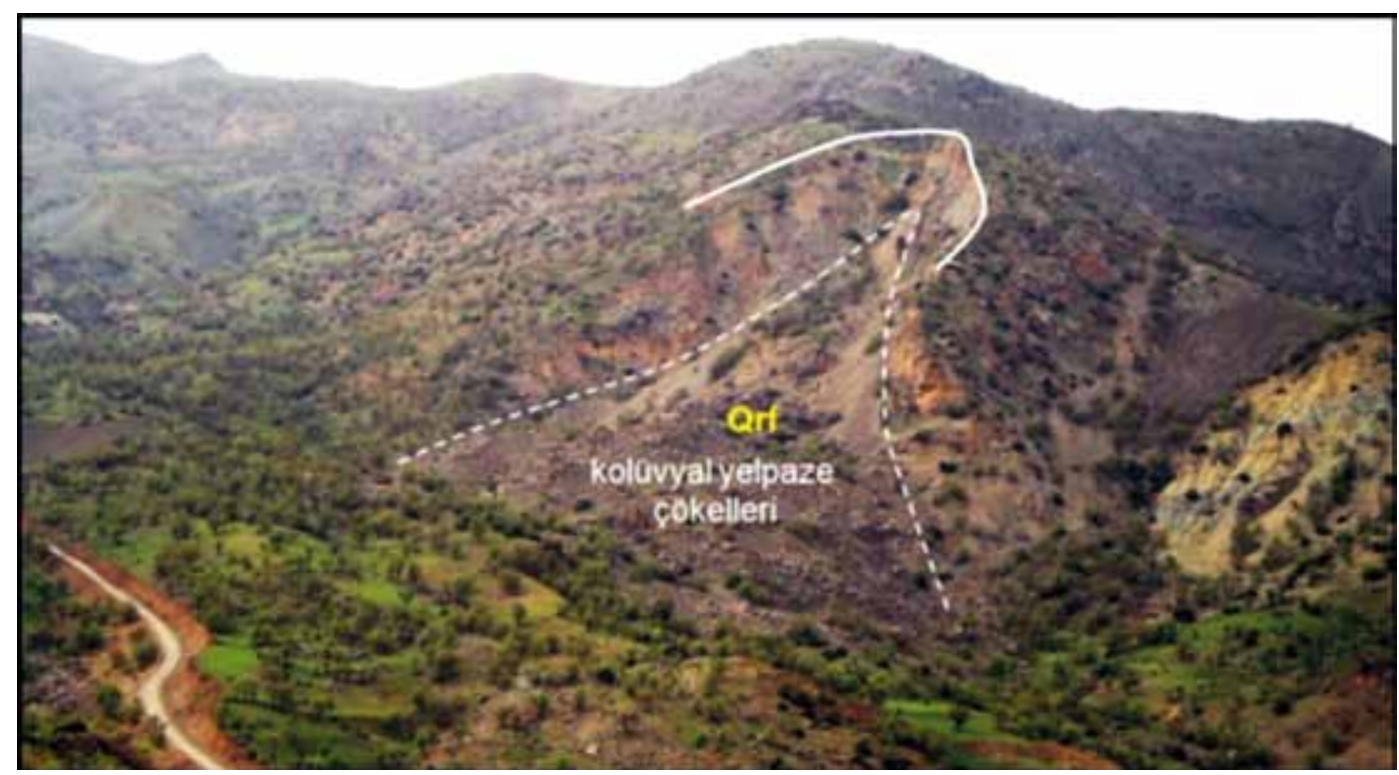

Şekil 37. Büyük Çay vadisi sağ sahilinde eski heyelan ve daha sonra heyelan taç alanından kaynaklanan kaya düşmesi (Qrf) ve yelpaze oluşturacak şekilde birikmiş kolluviyal Heyelan malzemesi ve yelpaze çökelleri. Heyelan malzemesi Çetin barajı göl alanına ulaşmamaktadır. Lokasyon için Şekil 34'e bakınız.

Figure 37. The old landslide on the right coast of the Büyük Çay valley and the rock fall and colluvial materials accumulated to form debris fan deposit derived from the crown of the landslide (Qrf: rockfall). The landslide debris does not reach to the Çetin dam reservoir area. For location; see Figure 34. 
İncecik Mahallesi batısında göreceli yaşları 4 olan dört adet heyelan haritalanmıştır (Şekil 7 ve 34). Bunlardan üç tanesi Büyük Çay vadisine bağlanan yan derenin kuzeyinde kalır. Heyelan malzemesi kuzeyden güneye akmıştır. Heyelan malzemesi daha sonraki evrede sularla tekrar taşınarak heyelan döküntüsü yelpazelerini oluşturmuştur (Şekil 37).

İncecik Mahallesi kuzeydoğusunda Büyük Çay vadisinin sol sahilinde nehir tabanından $60 \mathrm{~m}$ yükseklikte eski alüvyon taraçası haritalanmıştır (Şekil 38). Taraçaların malzemesi tutturulmuştur. $\mathrm{Bu}$ taraçalar üzerinde yamaç döküntüsü birikmiştir.

Baraj gölü oluştuktan sonra Beyaz Köprü su altında kalacaktır. Beyaz köprü dolayında Bitlis Metamorfitleri'nin mostraları görülür. Birim burada metamorfik şist ve kristalize kireçtaşı ile temsil olunur. Beyaz Köprü'nün batısında Maden Karmaşı̆̆ı'nın yastık lavlı volkanitleri görülür (Şekil 5 ve 39).

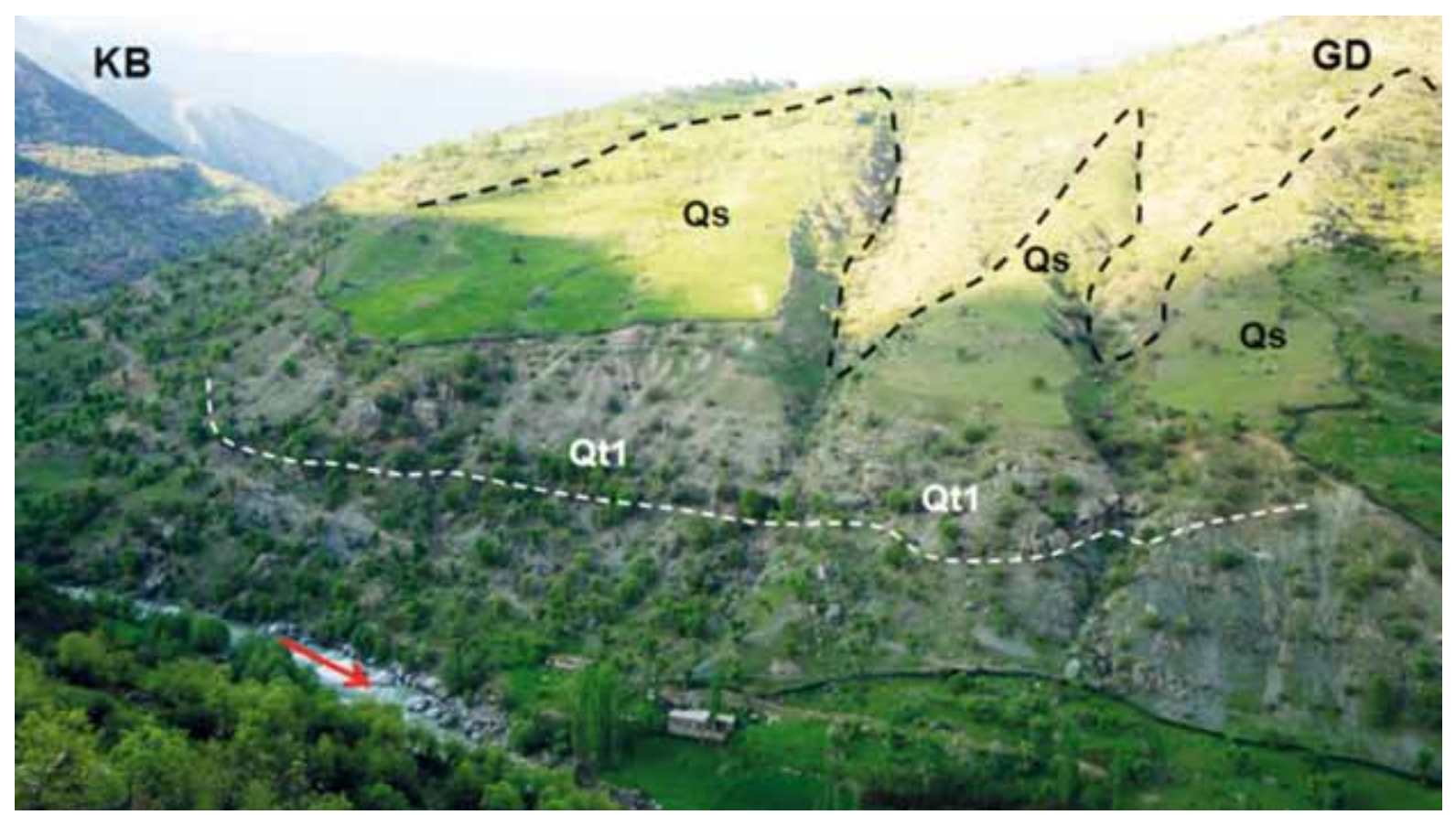

Şekil 38. Büyük Çay vadisi sol sahilinde güncel akarsu tabanından yaklaşık $38 \mathrm{~m}$ yükseklikte eski alüvyon taraçası (Qt) çökelmiştir. Taraça çökelleri kısmen çimentolanmıştır ve bunların üzerine yamaç döküntüsü birikmiştir (Qs). Kırmızı ok akış yönünü göstermektedir. Darıcık Köyü fotoğrafın alt kenarına yakın ortada görülmektedir. Lokasyon için Şekil 34 ve 39'a bakınız.

Figure 38. On the left coast, old alluvial terrace (Qt) was deposited $38 \mathrm{~m}$ higher than the present day river floor. The terrace deposits were partly cemented and above them scree is deposited (Qs: talus-scree). The red arrow indicates the flow direction. Darlclk Village is located in the lower part of the picture. For location; see Figures 34 and 39. 


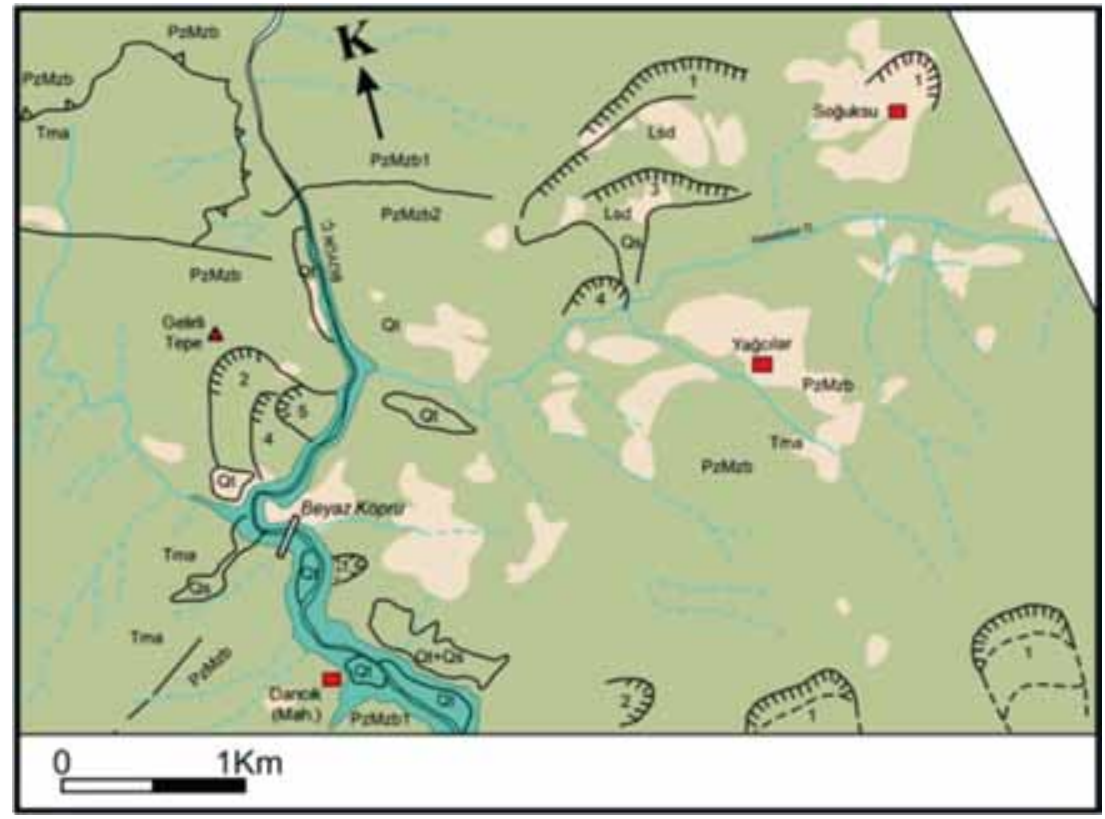

Şekil 39. Darıcık - Yağcılar alanının heyelan haritası.

Figure 39. Landslide map of the Darıclk-Yağcllar area.

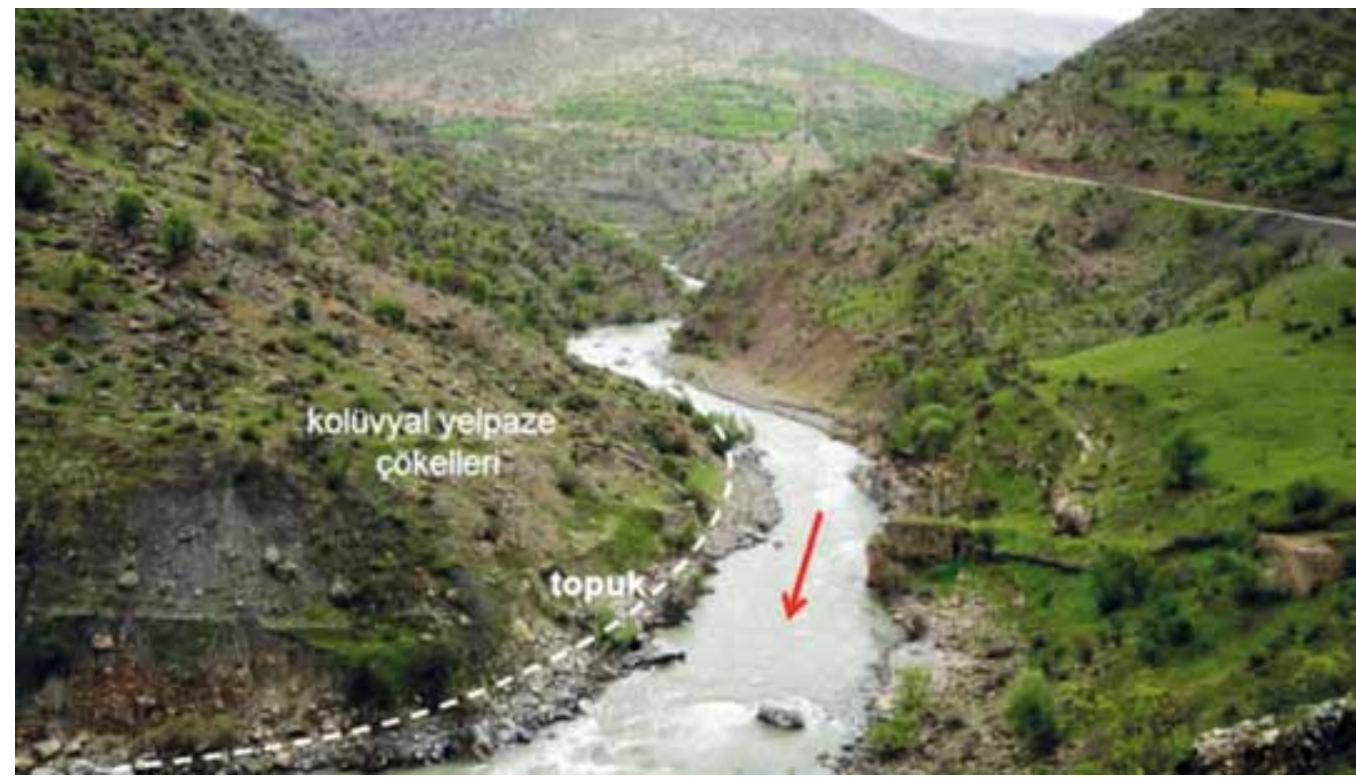

Şekil 40. Büyük Çay sağ sahilinde Beyaz Köprü kuzeyinde sağ sahilde heyelan topuğuna bakış. Topuk malzemesi heyelan oluşumundan sonra heyelan bölgesinde akan su ve yağmur ile yeniden işlenmiştir (kolüvyal yelpaze çökelleri). Yelpaze çökelleri nehri sol sahil yönünde ötelemiştir. Kırmızı ok akış yönünü göstermektedir. Lokasyon için Şekil 39'a bakınız.

Figure 40. View to the landslide toe that reach down to the river to the north of the Beyaz Bridge on the right coast of the Büyük Çay river. The toe material was re-processed by the waters (as debris fan deposit) flowing from the creek in the landslide area after the occurrence of the landslide. Landslide debris fan deposit has diverted the river towards the left coast. The red arrow shows the flow direction. For location; see Figure 39. 
Darıcık Mahallesi'nin 1500 m kuzeyinde iç içe üç adet heyelan saptanmıştır (Şekil 39). Gelirli Tepe'ye yakın olan heyelanın göreceli yaşı 2 olarak kabul edilmiştir. Bunun daha güneyinde göreceli yaş1 4 ve 5 olan iki heyelan daha vardır. Bunlar eski heyelan malzemesinin üzerinde gelişmişlerdir. Söz konusu her iki heyelanın topuk kısımlarındaki malzeme Büyük Çay yatağını güney yönde ötelemiştir (Şekil 40). Ötelemeyi sağlayan mekanizmaya heyelan sonrası yamaçtaki derelerden gelen mevsimlik akarsuların katkısı da vardır.

Baraj göl alanı Beyaz Köprü'nün 1750 m kuzeyinde sonlanır (Şekil 39). Bu alanın doğusunda Soğuksu Köyü dolayında ve batısında farklı yaşlarda 4 heyelan haritalanmıştır. Bunlardan en kuzeydeki heyelan eskidir (göreceli yaş:1). Güneye doğru heyelanların gençleştiği gözlenmiştir (Şekil 39).

\section{Çetin Baraj dolayında gözlenen eski aşınma yüzeyi - taraçaların tartışılması}

Çetin Barajı - Pervari dolayında eski aşınma düzlükleri ve bunların bazılarının üzerinde birikmiş bulunan Kuvaterner çökelleri çalışma sırasında haritalanmıştır (Şekil 7).

Bölgede beş farklı yükseklikte sekinin varlığı saptanmıştır. Bunlardan en eski olan seki için veri çok sınırlıdır. Gözlenebilen en eski seki verilerine Ayvalıbağ Köyü kuzeyinde sağ sahilde Sivri Tepe dolayında rastlanır. Bu sekinin yüksekliği 1550 metredir. Aynı yaştaki sekilerin sol sahildeki örnekleri, Pervari Siirt karayolu üzerinde Göl Mahallesi dolayındadır. Burada $1600 \mathrm{~m}$ ve $1620 \mathrm{~m}$ kotlarındaki düzlüklerin Sivri Tepe dolayındaki sekilerle eş yaşlı olduğu düşünülmektedir.

İkici seki grubu ise sol sahilde Ormandalı Köyü dolayında (1380 m) ve sağ sahilde Yalkaya
Köyü kuzeyinde Mağara Tepe doğu ve batısında (1340 m, 1370 m ve 1390 m) gözlenmiştir.

Üçüncü seki grubu ile ilgili veriler oldukça fazladır. Çukur, Gökbel, Güleçler köyleri ve bunlar ile benzer yükseklikteki sekiler bu grup içindedir. $\mathrm{Bu}$ sekilerin yüksekliği $1050 \mathrm{~m}$ ile $1100 \mathrm{~m}$ arasında değişir. Sağ sahilde heyelan alanında haritalanan sekinin de bu grupta olduğu düşünülmektedir (Şekil 19). Söz konusu sekilerin yüksekliği 1000 m-1050 m arasındadır.

Dördüncü seki grubunun bulunduğu yükseklik $850 \mathrm{~m}$ ile $900 \mathrm{~m}$ arasında değişir. Çalışma alanın memba tarafındaki sekileri 900 $\mathrm{m}$, mansap yönündeki sekiler $850 \mathrm{~m}$ dolayında bulunur. $\mathrm{Bu}$ grup sekiler üzerindeki yerleşimler batıdan doğuya Uçoluk, Ayvalıbağ ve Narsuyu köyleridir.

Beşinci gruptaki sekiler ise akarsu vadisine yakındır. Bu gruptaki taraçalar-sekiler bölgenin en genç taraça grubudur fakat kendi aralarında da farklı yaşlarda olduğu saptanmıştır. $\mathrm{Bu}$ grup içinde de üç ayrı yükseklikte taraça haritalanmıştır (Şekil 10, 14, 26 ve 38).

\section{SONUÇLAR VE ÖNERİLER}

Marn, kumtaşı, volkanit litolojilerinden oluşan Maden Karmaşı̆̆ 1 heyelanların sebeplerinden biridir. Yamaç eğiminin çok yüksek olması ise heyelanların en önemli nedenidir. $\mathrm{Bu}$ nedene Maden Karmaşığı'nın varlığı da eklenince heyelan miktarı artmıştır. Botan Çayı (Ulu Çay) vadisi boyunca yamaç eğiminin yüksek olmasının nedeni bölgeyi Orta Miyosen'den beri etkileyen tektonizmadır. Bölgenin devamlı yükseldiğini gösteren çok sayıda verilerden en önemlileri eski nehir yatağının aşınma düzlükleri ve taraçalardır. Bunlar heyelanların göreceli yaşlarını anlamada önemli ipuçları verirler.

Çetin Baraj1 - Pervari dolayında eski aşınma düzlükleri ve bunların bazılarının 
üzerinde birikmiş bulunan Kuvaterner çökelleri çalışma sırasında haritalanmıştır. Bölgede beş farklı yükseklikte sekinin varlı̆̆ı saptanmıştır. Gruplandırılan sekilerin yaşları farklıdır. Bunlar bölgenin yükselim tarihi anlaşılmasını sağlamaktadır.

Heyelanı tetikleyecek diğer bir neden ise depremlerdir. Güneydoğu Anadolu bindirme kuşağında zaman zaman depremler olmaktadır. Depremlerin tetiklemesiyle bölgede yeni heyelanların gelişmesi beklenmektedir. Depremin tetikleyeceği ve oluşturacağ önceden kestirmek oldukça zordur.

Çalışma alanında yer alan heyelanlar göreceli yaşlar dikkate alınarak 7 gruba ayrılmıştır. Bunlardan 6 ve 7 numaralı heyelanlar aktif diğerleri pasif heyelanlardır.

Gökçekoru Köyü kuzeybatısında, GölgeliAyvalıbağ köyleri arasında, Ayvalıbağ Köyü kuzeyinde ve Narsuyu Köyü doğusunda saptanmış olan ve haritaya kırmızı ile renklendirilerek işaretlenmiş heyelanlar en genç ve aktif heyelanlardır. Baraj gölü suyunun toplanmaya başlandığı ilk yıllarda su altında kalacak olan bu alanlarda toprak-kaya su doygunluğunun artmasina paralel olarak yeni heyelanlar olmas1 beklenmelidir. $\mathrm{Bu}$ alanlar baraj göl suyu etkisi olsa da olmasa da zaten heyelan bölgeleridir. İlkbahar aylarında miktarı artan yüzey suyu ve yeraltı suyu söz konusu alanlarda ve bölgenin diğer kesimlerinde heyelanlara sebep olmaktadır.

Aktif heyelanların olduğu alanların yüz ölçümü fazla değildir. Gökçekoru kuzeybatısındaki aktif heyelan alanı Gölgeli Ayvalıbağ arasında kalan aktif heyelan alanında bahçe ve köy evi yoktur. $\mathrm{Bu}$ alanlarda heyelanların vadi tabanındaki topuk kısmına Bitlis Metamorfitleri'nden alınacak kuvarsit ve kristalize kireçtaşından oluşacak bloklar konularak topuk kısmının duraylılığ1 sağlanmalıdır. Ayrıca bu alanda yapılacak drenaj sistemiyle yüzey suyunun zemine sizma oranı azaltılmalıdır. Böylece bu alandaki heyelanların baraj göl alanına zarar vermesi önlenmiş olacaktır. Narsuyu batısı ve Ayvalıbăg kuzeyindeki aktif heyelan alanlarında ise bahçeler vardır. $\mathrm{Bu}$ iki alan haritalara kırmızı renk ile işaretlenmiştir. Ayvalıbağ Köyü kuzeyindeki $1000 \mathrm{~m}$ boyunda 250 m enindeki alan ve Narsuyu Köyü doğusunda $1250 \mathrm{~m}$ boyunda $300 \mathrm{~m}$ enindeki alan riskli bölgelerdir. Buralarda topuk kısmına ağırlık koyma ve drenaj ağı oluşturma işlemleri de yapılmalıdır. Oluşturulacak drenaj sistemi zemine su girişini azaltacak ve gelecekte olacak kaymaları kısmen de olsa önleyecektir.

\section{KATKI BELİRTME}

$\mathrm{Bu}$ çalışmanın gerçekleşmesi için arazi çalışması için imkânlar ve gerekli veri seti Temelsu Uluslararası Mühendislik Hizmetleri A.Ş tarafından sağlanmıştır. Bu imkânları sağlayan Temelsu kuruluş ve elemanlarına teşekkürü borç bilirim.

\section{EXTENDED SUMMARY}

Purpose of this study is to locate the landslides that can threaten the settlement areas around the Çetin dam reservoir which is planned to be constructed on Botan Çayı (Ulu Çay) located in vicinities of Pervari town of Siirt city.

The Çetin dam crest, reservoir and upstream-downstream areas are all located on allochthonous units. In the study area (Figure-1) metamorphic rocks (Bitlis Metamorphics) in general crop out. The Maden Complex (LowerMiddle Eocene) is situated between the slices of the metamorphic rocks (Figure 4). This unit is comprised of mudstone, pelagic limestone, volcanic rocks (Figure 5) and shale-sandstone 
intercalation and is one of the causes of the landslides. When the unit is saturated with water, the mudstone and shale levels forms sliding planes and the overlying metamorphic rocks move above these planes towards the bottom of the valley as landslides.

Another allochthonous unit around the dam site is an assemblage of serpantinized ophiolitic rocks (Guleman Group) (Figures 3 and 6). This unit is intensively tectonized and the serpentine levels are causes of landslides. The Çüngüss Formation (Figures 2 and 3) is represented by Eocene-Miocene sandstone and marl intercalations. It creates suitable conditions for landslides where exposed. Since the outcrops of the Guleman Group and Çüngüş Formation are away from the dam site, the landslides caused do not pose a threat for the dam.

The dam site for the Çetin Dam is going to be constructed in Botan Çayı (Ulu Çay) valley where steeply inclined slopes are observed (Figures 17, 19, 21, 23, 24 and 33). Very steep inclination of the valley slopes are among the significant causes of the landslides. The frequency of the landslides increases when this feature is combined with the presence of the Maden Complex.

The reason why the slope inclination is steeper along Botan River is the tectonism which affected the region since the Middle Miocene. The Southeast Anatolian thrust belt is being compressed in north-south direction since the Middle Miocene (Perinçek, 1980a).

Among the most important numerous data that shows that the region is uplifting continuously. Elevated erosional surface of the old rivers and the terraces (Qt) can be counted as evidence of uplifting (Figures 9, 10, 11, 14, 15, 16, 19, 20, 21 and 36). During the geological mapping in the study area the erosional surfaces-terraces were also mapped. These features provide important evidences to understand the relative ages of the landslides. As the region uplifts, the river deepens its valley and dissects the skirts of the old landslide. Uplift and following erosion removed the mass in the old landslide toes trigger new landslides. In line with the uplifting of the region, the river downcuts its bed. The uplifting causes an increase in slope inclination. As the inclination of the slopes increase, new and younger landslides occur in debris of the older landslides (Figures 11, 12, 14, 16 and 39).

Based on their relative ages, the landslides mapped were classified into 7 groups. The symbol «1» was used for the oldest landslide and similarly, "7» was used for the youngest one. The relative ages of the landslides were indicated next to them on the map in many cases.

When the landslides were dated relatively, the following criteria were taken into consideration:

1. Elevation of the landslides from the present day river floor (Figures 17, 19, 35 and 36),

2. Elevation of the surface of separation beneath the landslide toe material (Figure 22),

3. Position and elevation of the flat area formed after the landslide in the area (Figure 15),

4. Rate of erosion of the landslide material and rate of transportation of this material to the valley floor (Figures 17 and 33),

5. Relation of the scree and alluvial terrace deposits formed after the landslide with the alluvial material. Amount of these materials,

6. Amount of washing of landslide material (excessive washing and translated matrix of the landslide material indicate that the landslide is old) (Figures 25, 32, 33 and 37),

7. The vegetation observed on the surface of the landslide material and its density (Figures 17, 22 and 23), 
8. Position of the trees on the landslide area (Figure 28), their relations with topography, whether they are affected from the landslide or not, the stage they are affected. The rate of growth of the tree before and after the landslide,

9. Whether any settlement exists on the landslide area or not, if exists, age of the settlement to interpret the age of the landslide (Figure 36),

10. Rate of erosion on the main scarp which forms the landslide crown (Figures 32, 35, 36 and 37),

11. Position of the material at the toe of the landslide, and rate of erosion. If the river bed is diverted (Figures 9, 21 and 40), rate of diversion and the amount of preservation of the diversion,

12. Relation of the landslides if they are nested (in most cases, young landslides are observed in older landslides) (Figures 11, 12, 14, 16 and 39 ).

The landslides with the figures «1,2,3,4 and 5» are the inactive, fossil landslides (Figures $8,11,16,20,34,35,36$ and 39). When the archaeological artifacts observed in the region are taken into consideration, it can be said that the landslide no. 1 to be belong to the periods before Christ (Figure 36). Most of the materials of the landslides no. 1 and 2 have been eroded significantly (Figures 17, 33, 35 and 36). Most of these landslides are hanging in line with fast uplift of the region; the toes of the landslides are located at higher elevations compared to the river floor. The landslides with figures « 6 » and « 7 » are active landslides (Figures 20 and 29).

The landslides also were grouped based on flowing-sliding types and flowing-sliding materials except for dating. A great part of the landslides plotted on the map have rotational or translational slide planes. However, landslides that can be grouped as rock fall and mudflow have also been mapped in the area.

It was observed in many places that the material sliding downslope following the occurrence of the landslide diverted the river bed in the opposite direction (Figures 21 and 40).

The areas where scree and slope washes are observed have also been plotted on the geological map in addition to the landslides and the terraces in the study area. After initial movement, the material of the old landslide (including the toe and head material) flow down into the valley to form new slope debris in line with deepening of the valley (Figures 17 and 33).

Most of the villages established on both banks along the valley of Botan Çayı (Ulu Çay) are located on old landslide material and landslide debris. The plain areas and erosional surfaces around these plains after the occurrence of landslides have become attractive for settlement (Figures 9, 15 and 36). The water emerging from the toe and foot of the landslide material has promoted the horticultural activities. Some villages, on the other hand, have been established on the accumulation areas of the slope debris, talus only (Figures 24 and 29).

Conclusions and Recommendations: The landslides located in the study area were grouped into 7 based on their relative ages. Of these, the landslides «6» and «7» are active while the others are not. Active landslide areas determined and marked in red. In line with the increase in water saturation of the rock and soil beneath the reservoir after water holding in the dam, new landslides can be expected around the active landslide areas. Another reason triggering the landslides is the earthquakes. It is very difficult to determine the locations of the landslides triggered by the earthquakes in advance. 
Stability of toes of the active landslide areas (6 and 7) must be provided by placing blocks of quartzites and kristalized limestone of Bitlis Metamorphics. Besides, the amount of water infiltrating to the subsurface must be reduced by applying a drainage system in these areas. Therefore, damage to the reservoir by landslides in these areas can be prevented.

\section{DEĞİNILLEN BELGELER}

Perinçek, D., 1979. Interrelation of the Arabian and Anatolian plates, Guidebook for excursion "B", First Geological Congress of the Middle East, Ankara, Turkey, $34 \mathrm{p}$.

Perinçek, D., 1980a. Arabistan Kıtası kuzeyindeki tektonik evrimin kıta üzerinde çökelen istifteki etkileri: Türkiye 5. Petrol Kongresi Tebliğleri, s. 77-93.

Perinçek, D., 1980b. IX. Bölge Hakkâri-YüksekovaÇukurca-Beytüşşebap-Uludere -Pervari dolayının jeolojisi: TPAO Rap., No. 1481, Ankara, yayınlanmamış.

Perinçek, D., 1990. Hakkâri ili dolayının stratigrafisi, Güneydoğu Anadolu, Türkiye: Türkiye Petrol Jeologları Derneği Bülteni. 2,.no.1, s. 21-68.

Perinçek, D. ve Çemen, İ., 1992. Late CretaceousPaleocene Structural Evolution of the Structural Highs of Southeastern Anatolia. Ozan Sungurlu Symposium, Proceedings. In Tectonics and Hydrocarbon Potential of Anatolia and Surrounding Regions. Turkish Petroleum Corporation - Turkish Association of Petroleum Geologists, p. 386-403.

Perinçek, D., ve Çemen. I., 1990. The structural relationship between the East Anatolian and Dead Sea fault zones in southeastern Turkey; Tectonophysics, v.172, p. 331-340.

Perinçek, D. ve Özkaya, I., 1981. Arabistan levhası kuzey kenarının tektonik evrimi: Yerbilimleri, Hacettepe Üniversitesi Yerbilimleri Enstitüsü Bülteni. No. 8. p. 91-101.
Perinçek, D., Duran, O., Bozdoğan N. ve Çoruh T., 1992. Stratigraphy and Paleogeographical Evolution of the Autochthonous Sedimentary Rocks in Southeast Turkey. Ozan Sungurlu Symposium, Proceedings. In Tectonics and Hydrocarbon Potential of Anatolia and Surrounding Regions. Turkish Petroleum Corporation - Turkish Association of Petroleum Geologists, p. 274-305.

Perinçek, D., Günay Y. ve Kozlu, H., 1987. Doğu ve Güneydoğu Anadolu bölgesindeki yanal atımlı faylar ile ilgili yeni gözlemler: Türkiye Yedinci Petrol Kongresi tebliğleri, s.89-104.

Sungurlu, O., 1974. VI. Bölge kuzeyinin Jeolojisi ye petrol imkanları, Okay and Dileköz (Eds.), Türkiye ikinci petrol kongresi tebliğleri, Türkiye Petrol Jeologları Derneği Bildiriler Kitabı, ss. 85107.

Sungurlu, O., Perinçek, D., Kurt, G., Tuna, E., Dülger, S., Çelikdemir E. ve Naz., H. 1985. Elazığ-HazarPalu alanının jeolojisi: T.C. Petrol İşleri Genel Müdürlüğü Dergisi, no. 29, s. 83-190.

Şengör, A.M.C., 1980. Türkiye'nin Neotektoniğinin Esasları, Geol. Soc.Turkey Conference Series 2, (in Turkish with English abstract).

Şengör, A. M. C. ve Yılmaz, Y., 1981. Tethyan evolution of Turkey: a plate tectonic approach: Tectonophysics, v. 75, p. 181-241.

U.S. Geological Survey, 2009. U.S. Department of the Interior; USGS Science Landslide Hazards program. http://3dparks.wr.usgs.gov/ haywardfault/images/slump.jpg), geology.com/ usgs/landslides/

\begin{tabular}{|c|c|}
\hline Makale Gelis Tarihi & : 24 Aralık 2015 \\
\hline Kabul Tarihi & : 22 Şubat 2016 \\
\hline Received & : 24 December 2015 \\
\hline Accepted & : 22 February 2016 \\
\hline
\end{tabular}


